\title{
CONSERVATION BIOLOGY OF FRESHWATER TURTLES AND TORTOISES
}

A Compilation Project of the

IUCN/SSC Tortoise and Freshwater Turtle Specialist Group

\section{EDITED BY}

Anders G.J. Rhodin, John B. Iverson, Peter Paul van Dijk, Craig B. Stanford, Eric V. Goode, Kurt A. Buhlmann, Peter C.H. Pritchard, and Russell A. Mittermeier

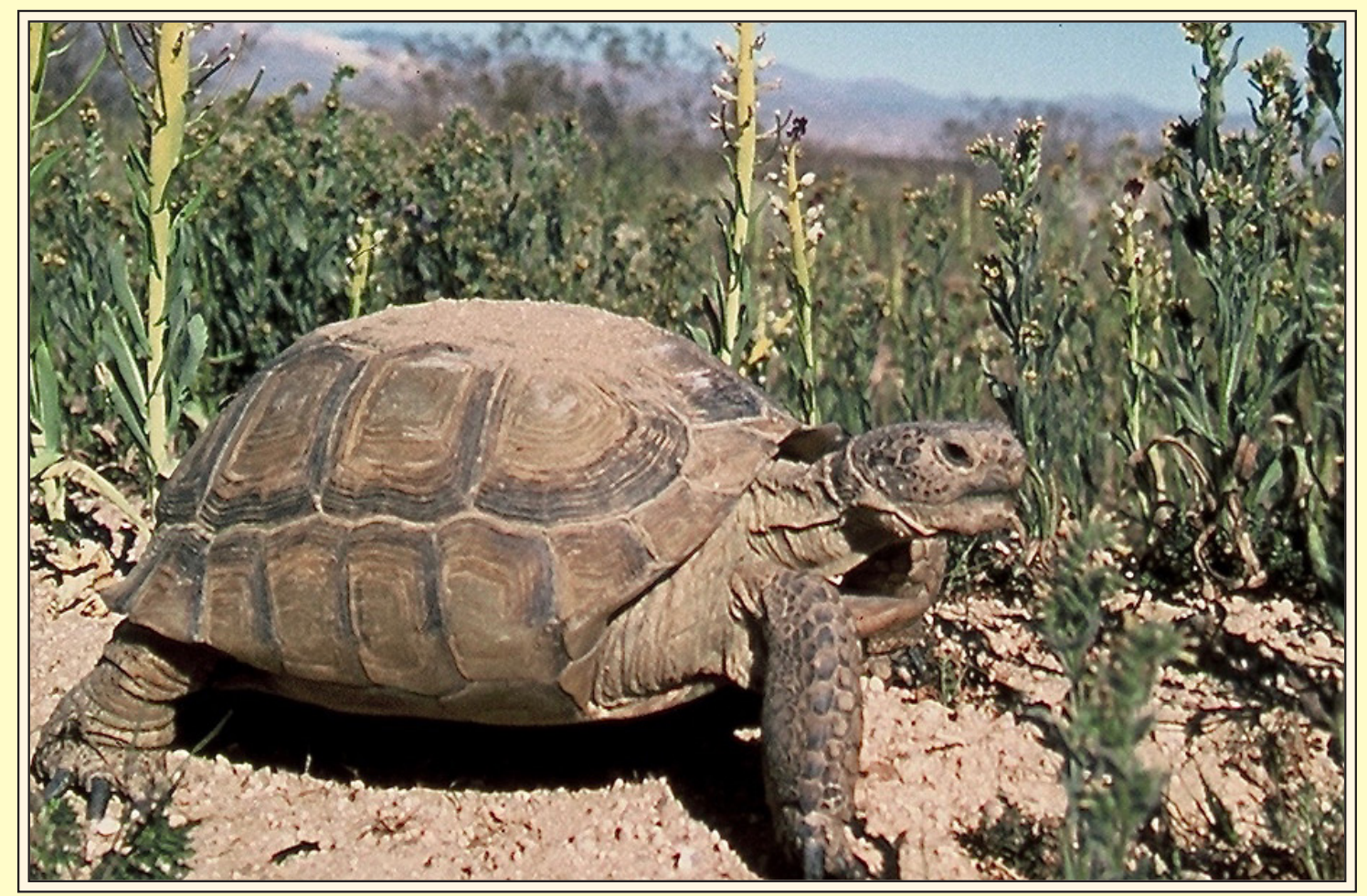

Gopherus agassizii (Cooper 1861) Mojave Desert Tortoise, Agassiz's Desert Tortoise

Kristin H. Berry ANd Robert W. Murphy

Chelonian Research Monographs

Number 5 (Installment 13) 2019: Account 109

Published by

\section{Chelonian Research Foundation and Turtle Conservancy}

in association with

IUCN/SSC Tortoise and Freshwater Turtle Specialist Group, Global Wildlife Conservation,

Turtle Conservation Fund, and International Union for Conservation of Nature / Species Survival Commission 


\title{
Gopherus agassizii (Cooper 1861) - Mojave Desert Tortoise, Agassiz's Desert Tortoise
}

\author{
Kristin H. Berri ${ }^{1}$ AND Robert W. MURPHY ${ }^{2}$ \\ ${ }^{1}$ U.S. Geological Survey, 21803 Cactus Avenue, Suite F, \\ Riverside, California 92518 USA [kristin_berry@usgs.gov]; \\ ${ }^{2}$ Royal Ontario Museum, Toronto, Canada [bob.murphy@utoronto.ca]
}

Summary. - The Mojave Desert Tortoise, Gopherus agassizii (Family Testudinidae), is a large terrestrial species that can reach $>370 \mathbf{~ m m}$ in straight midline carapace length $(\mathrm{CL})$ but most individuals are smaller. Both sexes reach adulthood at 12 to 21 years and ca. $180 \mathrm{~mm}$ CL. The species is sexually dimorphic, with males typically larger than females; sexual characteristics of males become more obvious with increasing size and age. Females lay from 1 to 10 eggs per clutch and from 0 to 3 clutches annually, with eggs hatching after 67 to 104 days. Populations of $G$. agassizii have declined rapidly over the last several decades. Habitat throughout the geographic range has experienced major losses, degradation, and fragmentation as a result of urban and agricultural development, livestock grazing, military activities, transportation and utility corridors, high levels of visitor use, vehicle-oriented recreation, and energy development. Disturbed habitats were vulnerable to invading non-native grasses and forbs, creating an unnatural and destructive grass-fire cycle. When consumed by tortoises as their only diet, non-native (and native) grasses are harmful because of limited nutrients. Additionally, subsidized predators (Common Ravens, Coyotes, and dogs), infectious diseases, drought, and vandalism, add to the catastrophic effects of habitat loss and degradation. Tortoise populations have declined rapidly in density, and most populations are below viability, with fewer than 3.9 adults $/ \mathrm{km}^{2}$. These declines occurred despite protections afforded by federal and state laws and regulations, ca. $26,000 \mathrm{~km}^{2}$ of federally designated critical habitat units, two Recovery Plans, and efforts to reduce the negative impacts of human activities. As noted by Allison and McLuckie (2018), the negative population trends in most of the critical habitat units suggest that under current conditions G. agassizii is on the path to extinction.

Distribution. - USA. Distributed in parts of the southern Great Basin, Mojave, and western Sonoran deserts in southeastern California, southern Nevada,northwestern Arizona, and southwestern Utah, north and west of the Grand Canyon/Colorado River complex, with the exception of a small population east of the Colorado River.

Synonymy. - Xerobates agassizii Cooper 1861, Testudo agassizii, Gopherus agassizii, Gopherus polyphemus agassizii, Scaptochelys agassizii,Xerobates lepidocephalus Ottley and Velázques Solis 1989.

SubSPECIES. - None currently recognized.

STATUS. - IUCN 2019 Red List: Vulnerable (VUA1acde+2cde; assessed 1996); TFTSG Provisional Red List: Critically Endangered (CR; assessed 2011,2018); CITES: Appendix II (Testudinidae spp.); US ESA: Threatened.

Taxonomy. - The Mojave Desert Tortoise was first described as Xerobates agassizii by Cooper (1861), transferred to the genus Testudo by Cope (1875) and to Gopherus by Stejneger (1893). It was listed as a subspecies of Gopherus polyphemus by Mertens and Wermuth (1955) and referred to the genus Scaptochelys by Bramble (1982). Gopherus lepidocephalus, described by Ottley and Velázques Solis (1989) based on introduced specimens from the Cape Region of Baja California Sur, Mexico, is a junior synonym of G. agassizii. Bramble erected Scaptochelys for the clade containing the western species of Gopherus, but this name was preoccupied (Bour and Dubois 1984). Recently, Bramble and Hutchison (2014) advocated for the splitting of Gopherus into two genera, including Xerobates (for the desert species and $G$. berlandieri), but the splitting seems unnecessary, and their proposed taxonomy has not been followed. Recent genetic and morphological work on the previously wide-spread species $G$. agassizii sensu lato has led to the recognition and description of the Sonoran or Morafka's Desert Tortoise, G. morafkai (Murphy et al. 2011) in Arizona and Sonora, Mexico, and the Sinaloan Thornscrub Tortoise, G. evgoodei (Edwards et al. 2016a) in southern Sonora and Sinaloa, Mexico, markedly limiting the range of G. agassizii sensu stricto.

Phylogenetic Relationships. - The genus Gopherus contains six species that consist of two major sister-groups: 


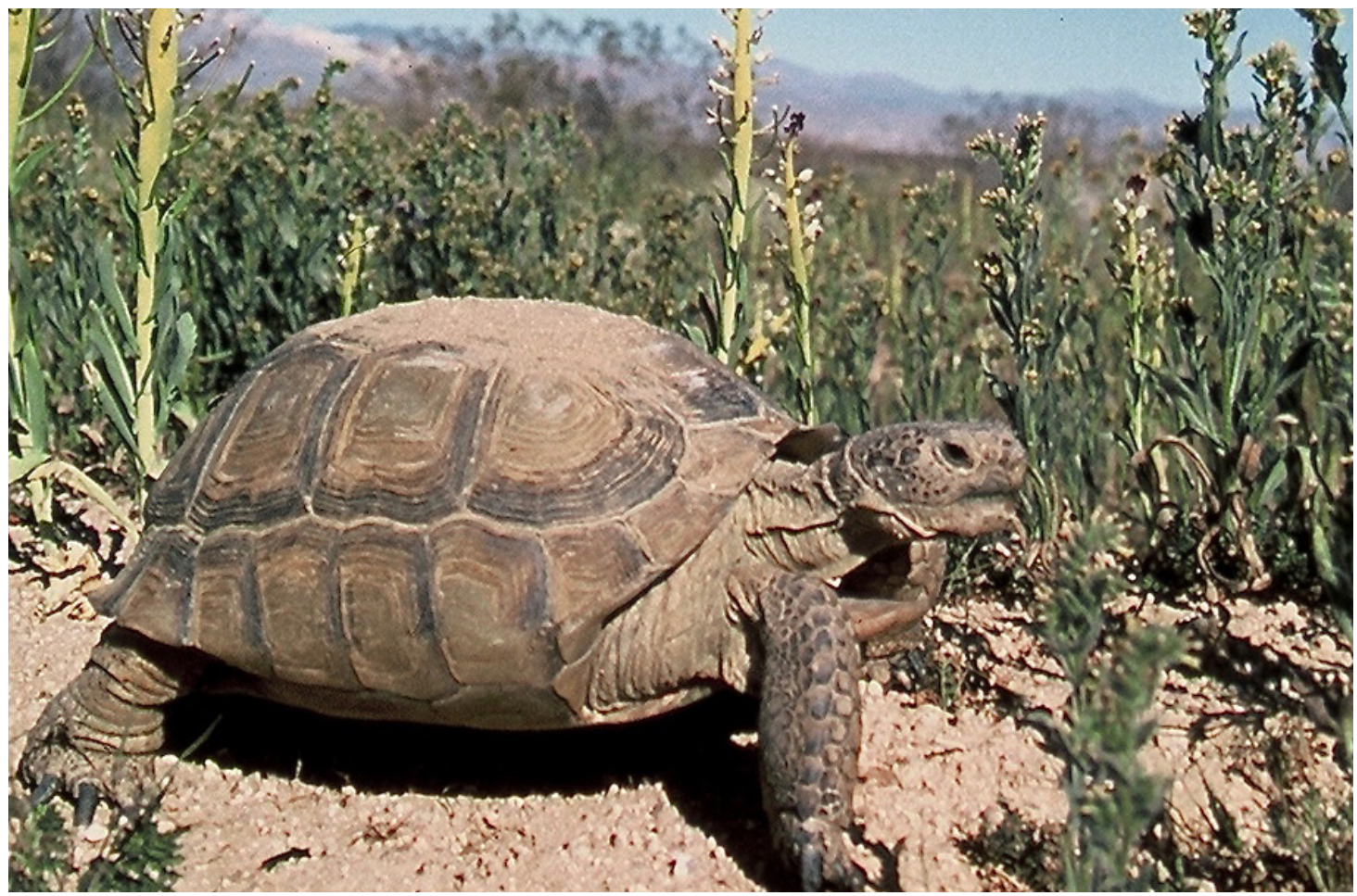

Figure 1. Adult Gopherus agassizii in desert candles at the Desert Tortoise Research Natural Area, Mojave Desert, California. Photo by Bev Steveson.

1) G. polyphemus and G. flavomarginatus, and 2) G. berlandieri, G. evgoodei, G. morafkai, and G. agassizii. The phylogenetic relationships in the second group are given in order of ascending relationships (Bramble and Hutchinson 2014; Murphy 2014; Edwards et al. 2016b). Gopherus evgoodei and G. morafkai may have originated via environmental-dependent parapatric speciation where exogenous selection limited genetic introgression (Edwards et al. 2016c). Later, the divergence of the sister species $G$. agassizii and G. morafkai may have been driven by either parapatric speciation or geographic isolation (Edwards et al. 2016b). Their divergence dates to about 4-8 million years ago, owing to the Bouse embayment (Lamb et al. 1989).

Description. - This and other sections focus primarily on peer-reviewed literature in journals and on recent articles summarizing topics. The published literature on G.agassizii contains papers on wild, free-ranging tortoises, tortoises maintained in small and large pens, head-started tortoises, and captives. For most topics, we emphasize studies on wild tortoises.

Adults of G. agassizii range in size from about 178 to $>370 \mathrm{~mm}$ straight-line, midline carapace length (CL). Females tend to be smaller than males (Table 1), but the
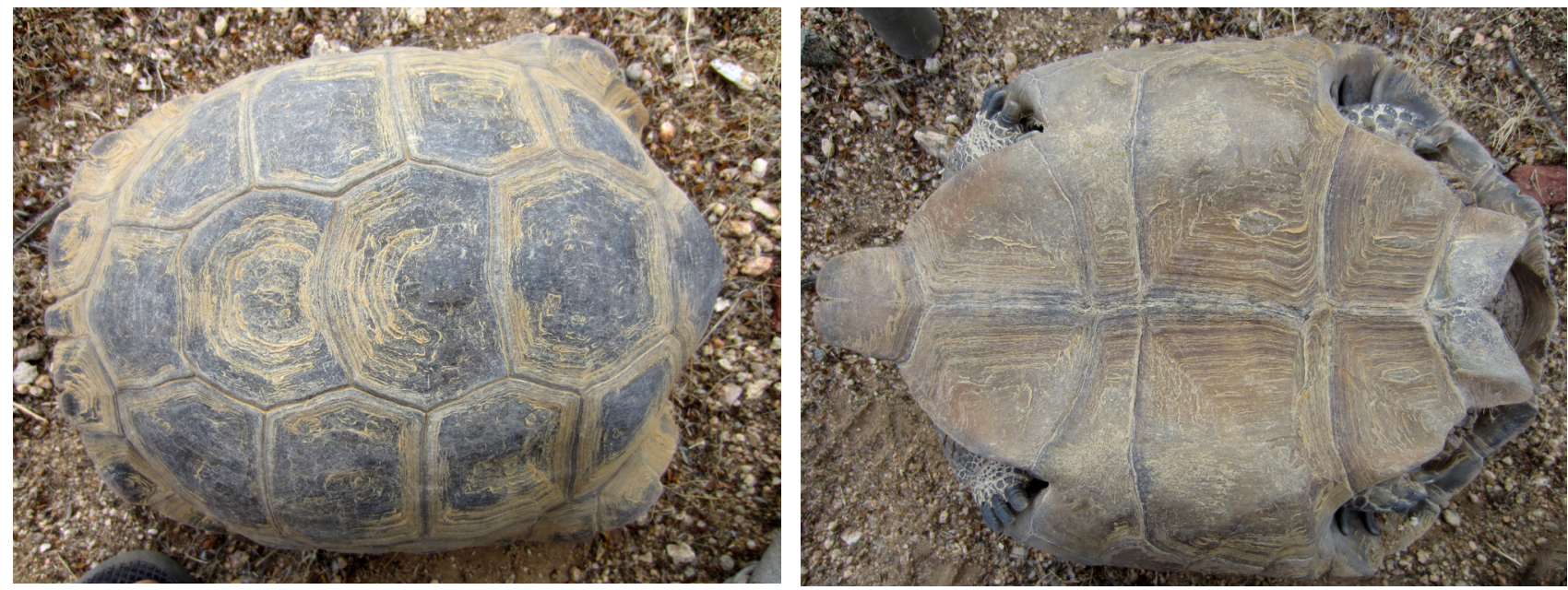

Figure 2. Adult male Gopherus agassizii from the Desert Tortoise Research Natural Area, Mojave Desert, California. First captured in 1979 at a CL of $292 \mathrm{~mm}$, he was recaptured repeatedly and in $2012 \mathrm{had}$ a CL of $300 \mathrm{~mm}$ (these photos) and estimated to be at least 70 years old. Photos by U.S. Geological Survey, courtesy of Kristin H. Berry. 


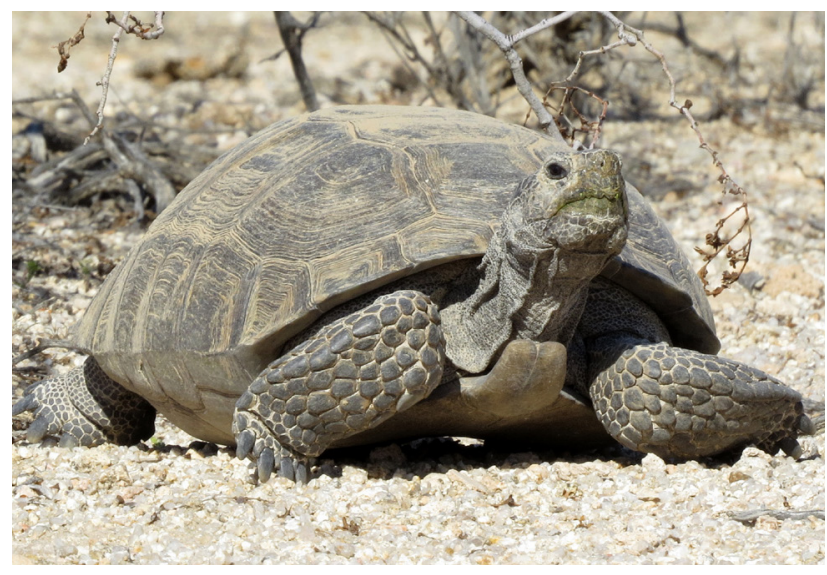

Figure 3. Adult male Gopherus agassizii at Chuckwalla Bench, California (Colorado Desert Recovery Unit). Photo by Steve Ishii.

largest recorded wild individual was a female from Lucerne Valley, California, first marked in 1980 at $364 \mathrm{~mm} \mathrm{CL}$ and recaptured in 1986 at 374 mm CL (U.S. Geological Survey files; Berry, unpubl. data). The largest recorded wild male was $330 \mathrm{~mm}$ CL, marked in 1982 at the Desert Tortoise Research Natural Area in the western Mojave Desert (Table 1). At that location, $8.9 \%$ of adult males were $\geq 300 \mathrm{~mm}$ CL. Larger tortoises may have been more common several decades ago. Ragsdale (1939) wrote that he frequently met healthy old tortoises 15 inches (ca. $380 \mathrm{~mm}$ ) CL across the back 25-30 years prior(1909-1914), before paved highways came to the Colorado Desert area.

The carapace shape ranges from relatively high-domed and rounded in the west to low-domed and oval in the southern and eastern part of the range. Females have a flat plastron, as compared to the posterior plastral concavity that develops and deepens in males as they age. Shapes of the gular horn and tail are secondary sexual characteristics that also distinguish adults. Adult males have a larger gular horn, generally becoming more pronounced and upturned with size and age. In contrast, females have a smaller, shorter, and generally flatter gular horn. The gular horn tends to be notched early in adulthood but notching may disappear in old adults. The tails in males are longer than in females,

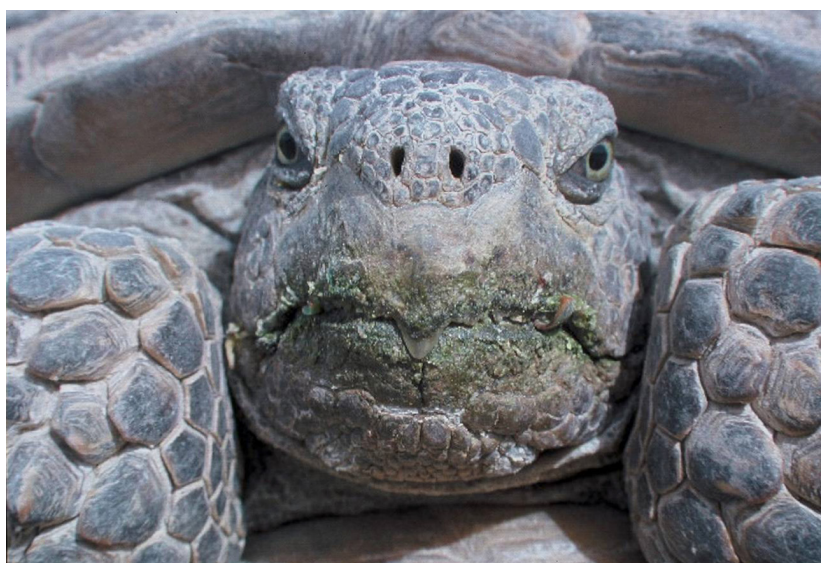

Figure 4. Adult Gopherus agassizii with a green beak (from foraging) in spring. Photo by Mark Massar.

projecting beyond the shell and often leaving a linear line or lines in sand when walking, whereas the tail of females does not extend beyond the carapace or plastron. Colors of the integument of limbs and shell vary with age and locality.

Bjurlin and Bissonette (2004) measured 91 wild hatchlings within 24 hours of emergence in the southern Mojave Desert, California; they had a mean CL of 43.8 \pm 2.15 (SD) $\mathrm{mm}$ (range $37.0-48.7 \mathrm{~mm}$ ) and a mean weight of 21.3 $\pm 2.91 \mathrm{SD} g$ (range 14.4-28.2). Shells vary from light (light yellow) to dark (dark charcoal) with and without lighter areolae, whereas young adults range from shades of light to dark brown, gray, or black with yellowish, reddish, greenish, and olive tones. Limb colors also vary with axillary and inguinal scales tending to be lighter than hindlimb pads and anterior surfaces of forelimbs.

Gopherus agassizii is best separated from congeners $G$. polyphemus and G. flavomarginatus by having relatively smaller feet. Further, the distance from the bases of the first and third claws on the front feet is about the same as the distance between the bases of the first and fourth claws of the hind feet in G. polyphemus and G. flavomarginatus, but the distance from the bases of the first to fourth claws is the same on all feet in G. agassizii (Auffenberg and Franz 1978). Gopherus agassizii and closely related G.berlandieri,

Table 1. Mean sizes and weights of adult female and male Mojave Desert Tortoises (Gopherus agassizii) in three desert regions of the geographic range of the species. $\mathrm{CL}=$ straight midline carapace length $(\mathrm{mm})$. None of the sites were in undisturbed habitat. The West Mojave site was grazed by cattle, then by sheep until 1980. The East Mojave site was grazed by cattle for decades previously, before and during the surveys. Both the East Mojave and Colorado Desert sites had tank tracks and litter from World War II military exercises.

West Mojave:

Desert Tortoise Research

Sizes and Weights

Natural Area Interior

Year sampled

Total sample size $(n)$ females, males

Mean CL, mm (range): females males

Mean weight, g (range): females males
East Mojave:

Fenner Valley

$\begin{array}{cc}1980 & 1979 \\ 188 & 175 \\ 77,111 & 80,95 \\ & \\ 4.5(183-247) & 222.3(188-254) \\ .5(182-307) & 243.3(190-291) \\ & \\ 8(1111-2915) & 2215(1350-3300) \\ 4(1115-6000) & 2897(1350-4750)\end{array}$

Colorado Desert: Chuckwalla Bench 

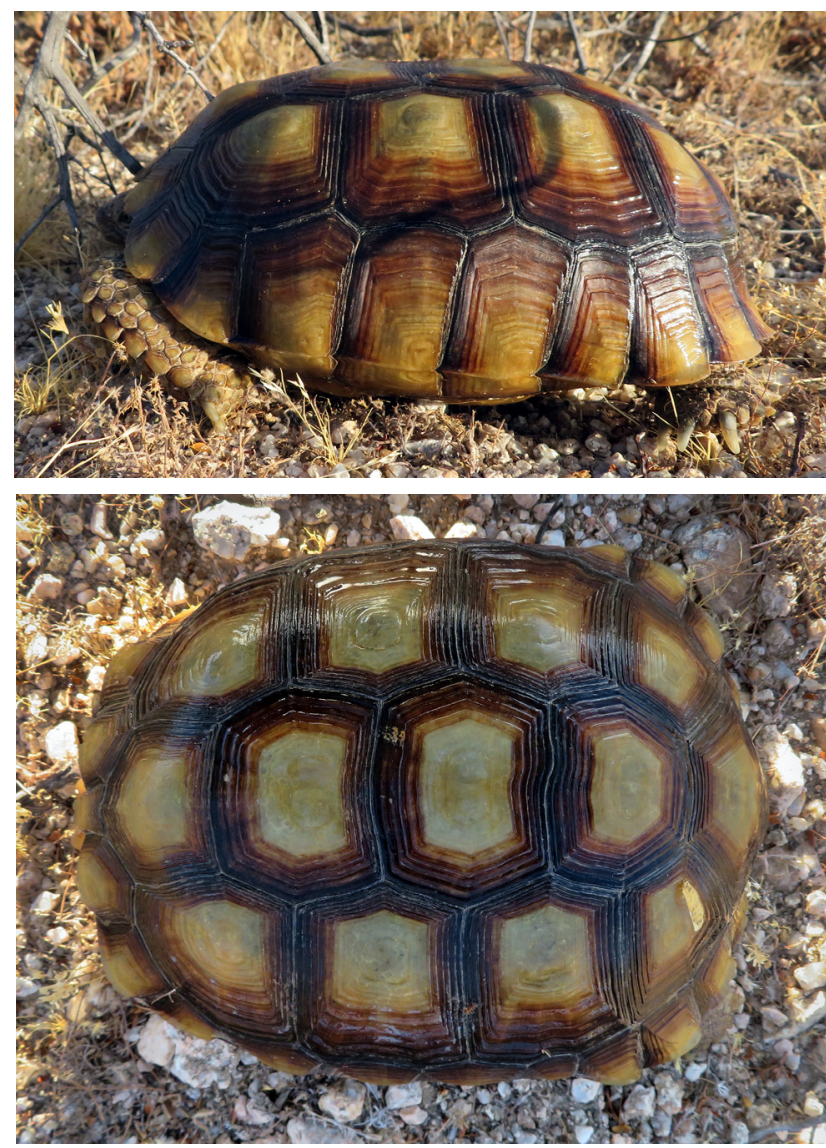

Figure 5. Young adult female Gopherus agassizii from Ward Valley in the Colorado Desert, California. Photos courtesy of San Diego Zoo Global.

G. morafkai, and G. evgoodei individuals are most reliably distinguished by molecular data, especially in captivity, owing to extensive hybridization (Edwards et al. 2010) and abnormalities in shell, head and limb integument resulting from poor nutrition (Murphy et al. 2011). In wild tortoises, G. berlandieri differs from G. agassizii (and G. morafkai and G. evgoodei) in having a wedge-shaped versus a rounded snout (Auffenberg and Franz 1978). Gopherus agassizii differs from G. morafkai in having a significantly wider shell (Germano 1993), significantly longer gular scutes, and a significantly longer length of projection of the anal scales (Germano 1993), as well as a box-like versus a pear-shaped shell (Weinstein and Berry 1989). Finally, G.agassizii and G. morafkai both differ from the newly described G. evgoode $i$ in having a higher shell in profile. Gopherus evgoodei also differs in having rounded foot pads, multiple enlarged spurs on the radial-humeral joint, a short tail, orange overtones in the skin and shell, and a distinctly shallower concavity on the plastron of males (Edwards et al. 2016a).

Distribution. - As originally described, the geographic range of Gopherus agassizii (sensu lato) extended from southeastern California, southern Nevada, and southwestern Utah south through Arizona and Sonora and into the northern part of Sinaloa, Mexico (Stebbins 1966; Auffenberg and
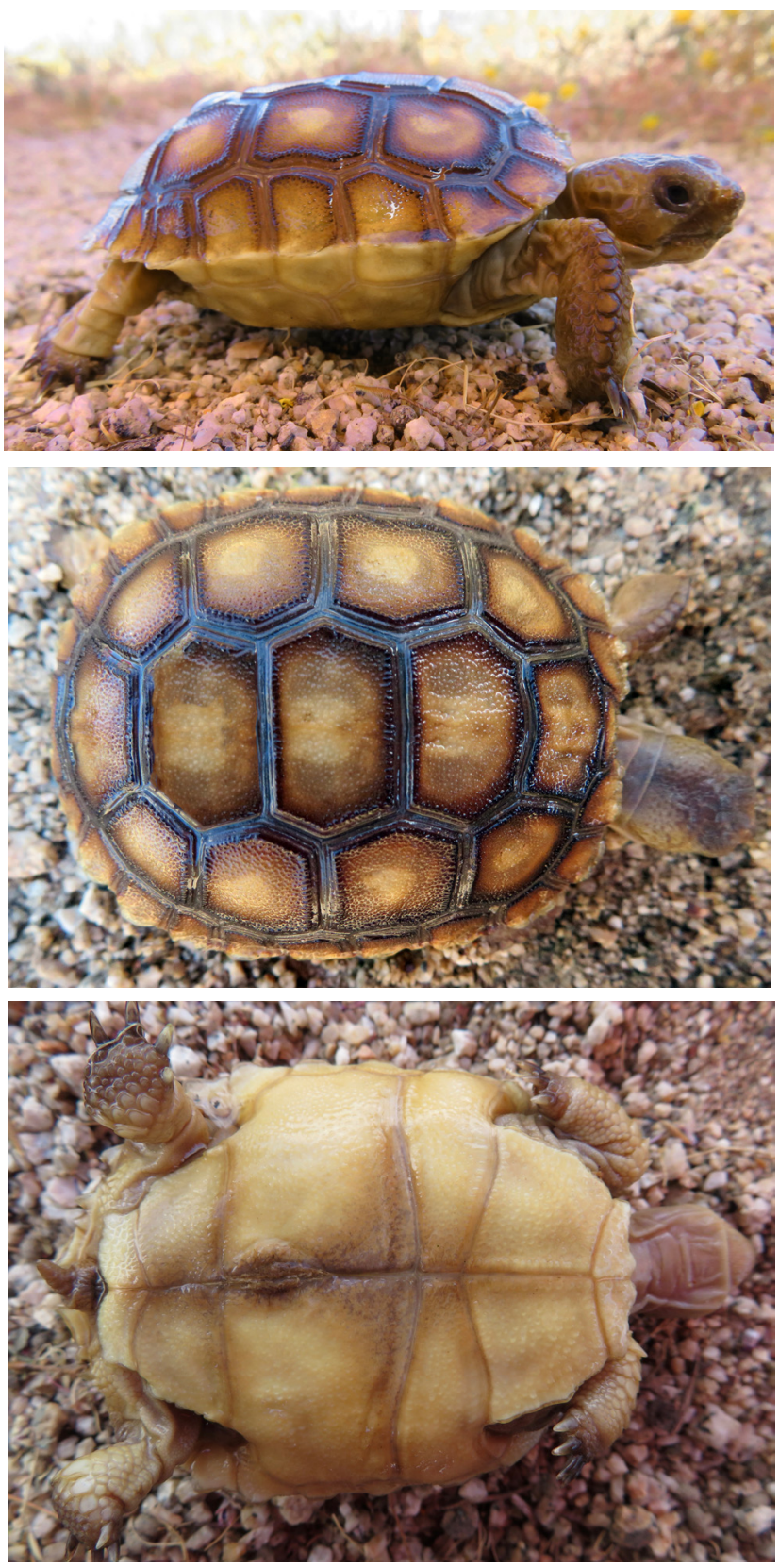

Figure 6. Hatchling Gopherus agassizii from Edwards AFB in the western Mojave Desert, California. Photos courtesy of San Diego Zoo Global.

Franz 1978). However, in 2011, G. agassizii was split into two species along the Colorado River (USA), with $G$. agassizii (sensu stricto) occurring to the north and west of the river, and the new species G. morafkai distributed to the south and east (Murphy et al. 2011). With this division, G. agassizii (sensu lato) lost about $70 \%$ of its originally defined geographic range. Five years later, G. morafkai was further split into two species, with G. evgoodei described as encompassing the southern part of the geographic range in central to southern Sonora and northern Sinaloa, Mexico (Edwards et al. 2016a).

The northernmost locations of G. agassizii are in southern Owens Valley, California, Beatty, Nevada, and Red Cliffs 


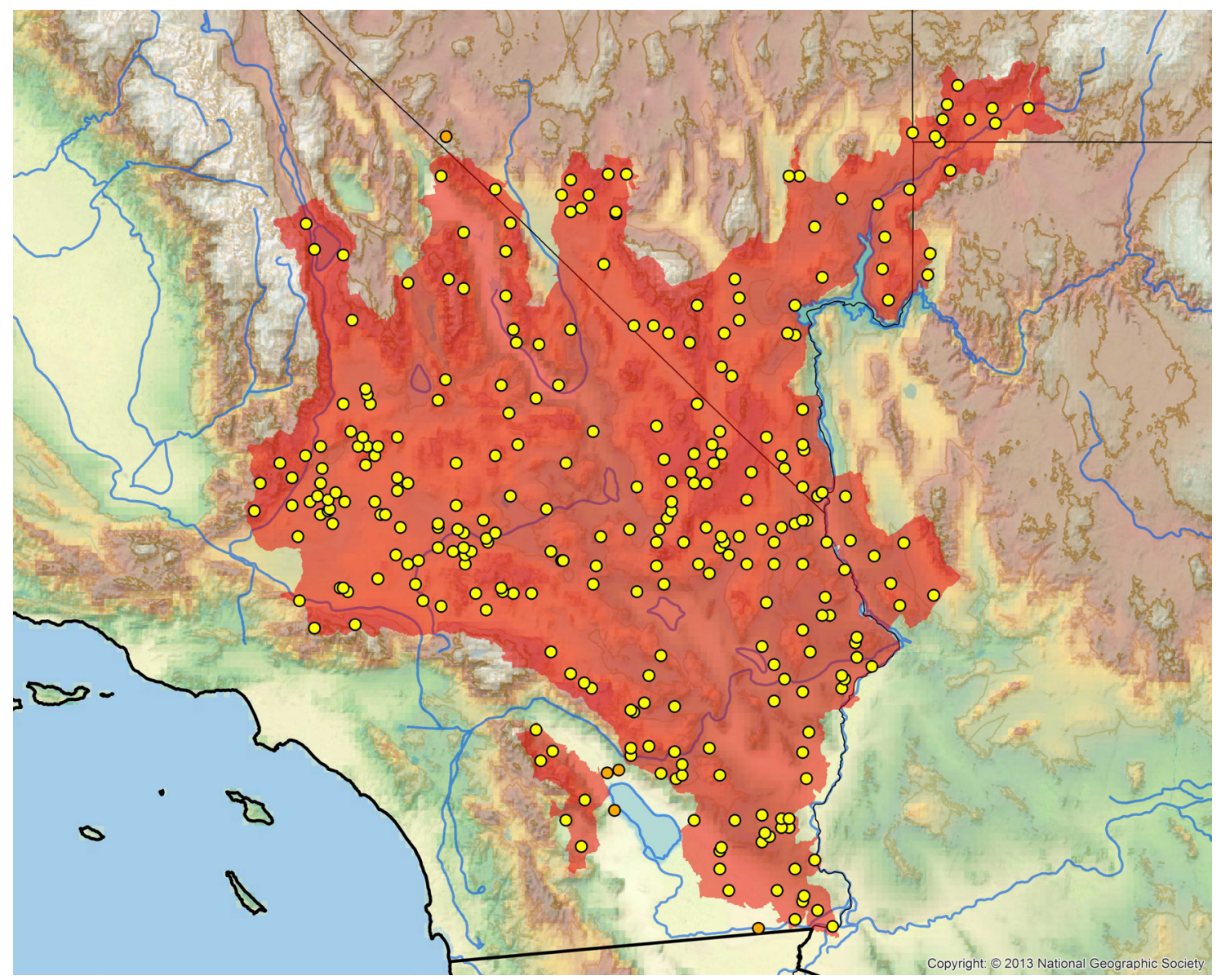

Figure 7. Distribution of Gopherus agassizii in California, Nevada, Utah, and Arizona in the USA. Yellow dots = museum and literature occurrence records of native populations based on Iverson (1992) plus more recent and authors' data; orange dots = uncertain native or introduced specimens; red shading = projected historic distribution. Distribution based on GIS-defined level 12 HUCs (hydrologic unit compartments) constructed around verified localities and then adding HUCs that connect known point localities in the same watershed or physiographic region, and similar habitats and elevations as verified HUCs (Buhlmann et al. 2009; TTWG 2017), and adjusted based on authors' subsequent data.

Desert Reserve and adjacent lands in southwestern Utah. The Colorado River forms the eastern and southern boundaries in California, parts of Nevada, northwestern Arizona, and Utah, with one exception. The exception to the Colorado River boundary is a small population of tortoises in Mojave Desert vegetation east of the Colorado River in the Black, Buck, and Hualapai mountains of Arizona (Edwards et al. 2015). Here, G. agassizii and G. morafkai meet in a contact zone where Mojave and Sonoran Desert vegetation types form an ecotone. With few exceptions, the two species have maintained their taxonomic identities. Nineteen hybrids were identified by Edwards et al. (2015), most as $F_{2}$ mixtures and were primarily in the ecotone; one additional hybrid individual, a backcross, was found in the Arrastra Mountains. $\operatorname{Inman}(2019)$ concurred, demonstrating separation of niches between the two species.

Most of the geographic range of G. agassizii occurs within the Mojave Desert and western Sonoran or Colorado Desert, with small areas of southern Great Basin Desert in the north and on the slopes of desert mountain ranges. The western boundaries of the range occur in ecotones with the lower slopes of the eastern Sierra Nevada and the Scodie and Tehachapi mountains, the lower north-facing slopes of the Transverse Range (specifically the San Gabriel and San Bernardino mountains), and the east-facing base of the Peninsular Range in the western Sonoran Desert. Using Recovery Units and critical habitat units or Tortoise Conservation Areas as a guide, approximately 55\% of Tortoise Conservation Areas are in the Mojave Desert and 45\% are in the western Sonoran Desert (USFWS 2015).

The boundaries of the historic geographic range of $G$. agassizii have contracted along the margins and fragmented in the interior, with losses from agricultural, urban, energy, and military developments, as well as transportation corridors and roads. Hundreds of square kilometers of tortoise habitat have been lost in the southwestern Mojave Desert, but do not yet show on maps of habitat (e.g., Nussear et al. 2009; Murphy et al. 2011). Similarly, major parts of valleys once supporting high densities of tortoises have become urban, ex-urban, and industrialized; examples include Indian Wells, Antelope, Victor, Apple, Chuckwalla, and Las Vegas valleys in California and Nevada, and St. 
George in Utah. Averill-Murray et al. (2013) modeled potential linkages between Tortoise Conservation Areas (critical habitat units).

Gopherus agassizii can be found in unusual places and ecosystems outside its geographic range. Captives frequently escape, are released or translocated (unauthorized) without regard to sites of origin. Animals found in the Cape Region of Baja California Sur, Mexico, were mistakenly described as the purported new species, G. lepidocephalus (Ottley and Velázques Solis 1989). In addition, mass authorized translocations have occurred (see summaries in Murphy et al. 2007). In a study of the genetics of 180 captive tortoises in three cities in Arizona within the range of G. morafkai, more than $40 \%$ were G. agassizii from the Mojave Desert or were hybrids (Edwards et al. 2010). In a similar study of 106 captive tortoises from three desert communities in the Mojave Desert, the genotypes of only $44 \%$ were $G$. agassizii of local origin, $55 \%$ were assigned to one of seven G. agassizii genetic units from outside the local area, and one tortoise was genotyped as G. morafkai (Edwards and Berry 2013).

Population Genetics. - Murphy et al. (2007) provided the first analysis of population differentiation across the landscape to assess the correspondence between Recovery Units in the 1994 Recovery Plan and genetic patterning. Their analysis used mtDNA sequences from 125 Desert Tortoises and 16 microsatellite loci of 628 animals collected from 31 sample sites. Analyses recovered substantial differentiation within the Western Mojave Recovery Unit. However, the authors had very limited sampling in Nevada and Utah.

Hagerty and Tracy (2010) performed a similar assessment using 20 different microsatellite loci with larger sampling in Utah, Nevada, and the northern deserts of California, but relatively poor sampling in the western and southern part of the species' range; they recovered an alternative pattern. Later, Hagerty et al. (2011) applied landscape genetic analyses to those data and recovered patterns that were largely compatible with those of Murphy et al. (2007) when considering sample sizes; larger sample sizes in northern areas for Hagerty and Tracy (2010) and southern areas for Murphy et al. (2007) yielded more details. The U.S. Fish and Wildlife Service's (USFWS) Recovery Office assumed that a strategy of random sampling would outperform strategic sampling of populations, and therefore relied on the Hagerty and Tracy (2010) study. Rico et al. (2015) modeled the two sampling strategies and discovered that strategic population sampling vastly outperformed random sampling, thereby giving credence to the study of Murphy et al. (2007).

Recently, Sánchez-Ramírez et al. (2018) evaluated 6,859 single nucleotide polymorphisms from 646 tortoises to reassess genetic patterns. Their results, which used newer genetic methods, were largely consistent with those of Murphy et al. (2007) in identifying significant genetic substructuring in the western Mojave Desert. Their analyses also identified 12 highly differentiated outlier genes likely involved in adaptations.

On a microgeographic scale, Desert Tortoises at a study area in the central Mojave Desert exhibited weak genetic structure (Latch et al. 2011). Analyses identified two subpopulations with low genetic differences and evidence of gene flow. Topography, specifically slope (the predominant factor) and roads, influenced local gene flow, with the changes considered to be recent.

Habitat and Ecology. - The geographic range of $G$. agassizii covers parts of three deserts and mountain ranges within and along their boundaries. Tortoises live in habitats ranging from $200 \mathrm{~m}$ to about $1570 \mathrm{~m}$ asl and in several vegetation associations (Weinstein 1989; Rautenstrauch and O'Farrell 1998; Longshore et al.2003; Keith et al.2008; Berry et al. 2006, 2014a). Tortoises require topography, geological features, and soils suitable for cover and construction of shelters-burrows or dens, under rocks or rock crevices, and in banks or walls of ephemeral washes (Woodbury and Hardy 1948; Burge 1978; Rautenstrauch and O'Farrell 1998; Andersen et al. 2000; Berry et al. 2006; Mack et al. 2015).

Habitat Use . - Cover of shrubs or trees is essential for protection from extremes of temperature, precipitation, and predators. Over $70 \%$ of cover sites (burrows, pallets) occur beneath shrubs, with the larger shrubs or trees preferred (Burge 1978; Berry and Turner 1986). The vegetation of shrubs, trees, cacti, and perennial grasses differs regionally within the Mojave, southern Great Basin, and western Sonoran ecosystems. Regional differences are based on timing and amounts of precipitation, numbers of freezing days, and other climatic variables and topographic features (Rowlands et al. 1982; USFWS 1994, 2011). For example, throughout the geographic range, most rainfall occurs in fall and winter. However, in the eastern and northeastern Mojave and western Sonoran deserts, summer rainfall is important, resulting in shifts in vegetation types. Similarly, numbers of annual freezing days are high in the north (e.g., Desert Game Range, Nevada: 126 days) dropping to just a few days in the southern part of the range in the western Sonoran Desert (1 to 16 days) (USFWS 1994).

Within the Mojave Desert ecosystem, tortoises occur in several vegetation associations. At lower elevations or adjacent to dry lake beds, saltbush associations (Atriplex spp.) and other members of the Chenopodiaceae provide habitat. The most common associations contain creosote bush (Larrea tridentata), usually with white bur-sage (Ambrosia dumosa) or cheesebush (A. salsola) and several other species of shrubs, cacti, and perennial grasses. With increasing elevation, multiple species of woody shrubs and tree yuccas (Joshua tree, Yucca brevifolia, and Mojave yucca, $Y$. schidigera) become more common, with blackbrush (Coleogyne ramosissima) associations 

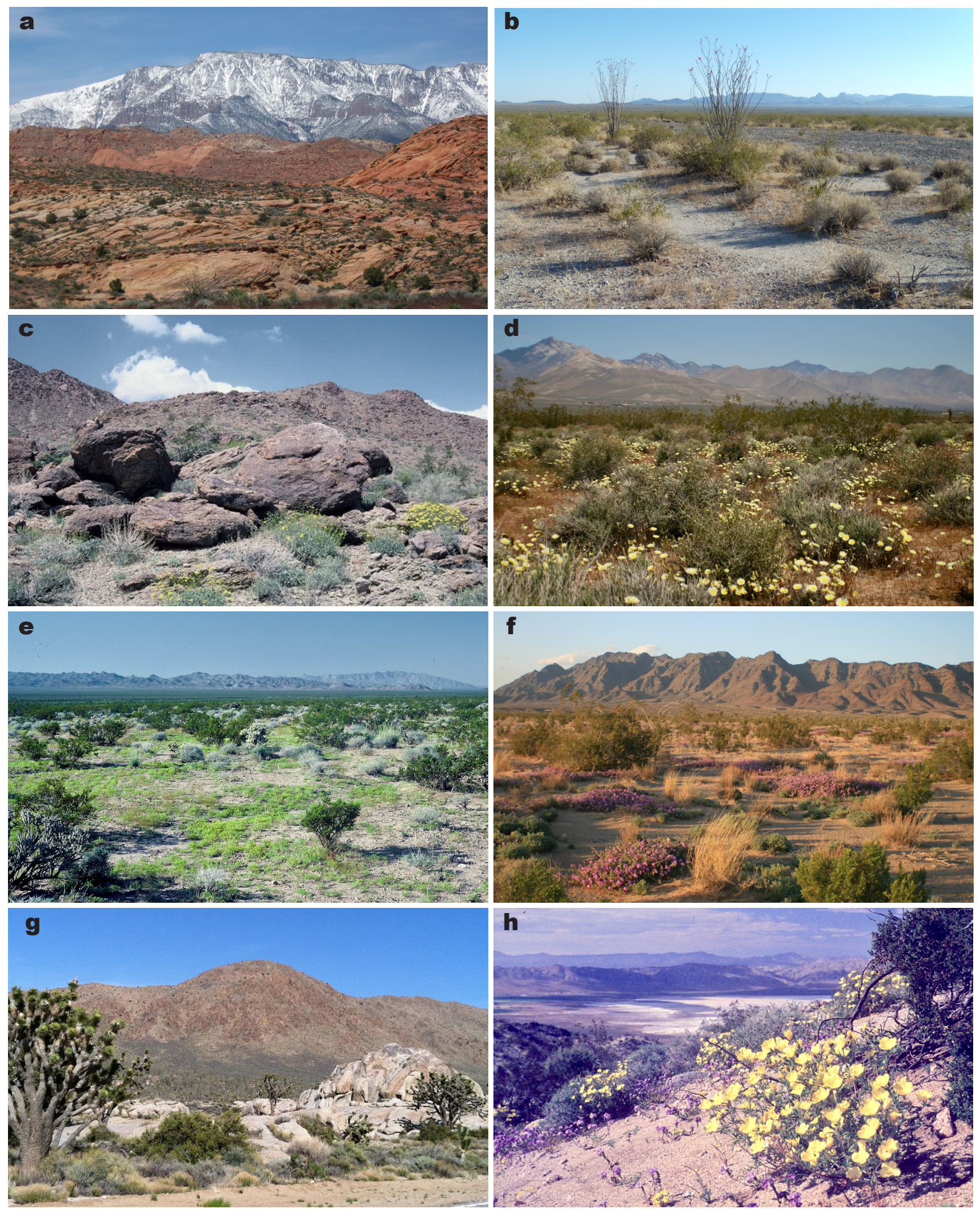

Figure 8. Habitats of Gopherus agassizii. a. Ecotone between Mojave and Great Basin deserts, Utah, Upper Virgin River Recovery Unit. Photo by Ann McLuckie. b. Chemhuevi Valley, Colorado Desert, California (creosote bush-ocotillo). Photo courtesy of U.S. Geological Survey. c. Soda Mountains, central Mojave Desert, California, Western Mojave Recovery Unit. Photo courtesy of U.S. Geological Survey. d. Northwestern Mojave Desert, California, Western Mojave Recovery Unit. Photo by Freya Reder. e. Eastern Mojave Desert, California, after summer rains, Colorado Desert Recovery Unit (formerly Eastern Mojave Recovery Unit). Photo by Betty L. Burge. f. Chuckwalla Valley, California, Colorado Desert Recovery Unit (formerly Eastern Colorado Recovery Unit). Photo by Freya Reder. g. Mojave National Preserve, California, Eastern Mojave Recovery Unit. Photo by Freya Reder. h. Desert Tortoise Research Natural Area, California, Western Mojave Recovery Unit. Photo by Kristin H. Berry. 
present in higher elevations. In the northeast corner of the geographic range, in the Red Cliffs Desert Reserve in Utah, vegetation is transitional between Mojave Desert and Great Basin, combined with sand dune systems. Sand sage (Artemisia filifolia), creosote bush, blackbrush, Nevada ephedra (Ephedra nevadensis), and big galleta (Hilaria rigida) are common (McLuckie et al. 2002).

The western Sonoran Desert is a warmer, hotter desert with a higher proportion of precipitation occurring in summer. This desert is also characterized by creosote bushes, but a major difference is the presence of microphyll woodlands of blue palo verde (Parkinsoniaflorida), smoke tree (Psorothamnus spinosus), and ironwood (Olneya tesota) in ephemeral stream channels separated by desert pavements or open desert with ocotillo (Fouqueria splendens) mixed with creosote bush, other shrubs, and cacti (Berry 1984).

More detailed descriptions of vegetation are in the first Recovery Plan and appendices, as well as in publications of individual field studies (USFWS 1994). Some sites have rich assemblages of shrubs, trees, cacti, and native bunch grasses, whereas others are low in shrub and grass diversity. Tortoises occur in very low densities or are absent where shrub cover is sparse, precipitation is low and timing erratic, and annual food plants are available only intermittently (e.g., the lower elevations in Death Valley). They are also in low densities in moderately to severely disturbed areas, regardless of desert or region (e.g., Bury and Luckenbach 2002; Keith et al. 2008; Berry et al. 2013).

Nussear et al. (2009) developed a quantitative habitat model using 16 layers of environmental data that were then joined with records on tortoise presence. Their model described the predicted habitat potential throughout the geographic range. This useful model does not exclude lands where tortoises no longer occur because of habitat lost to urbanization, agriculture, and other anthropogenic activities resulting in deteriorated habitat.

Adaptations. - Tortoises have several adaptations or exaptations for dealing with environmental extremes found within the geographic range, including behavioral responses, such as use of the burrow, cave, or den to escape extremes in environmental temperatures (e.g., Woodbury and Hardy 1948; Mack et al. 2015). They also exhibit physiological, hematologic and plasma biochemical responses for coping with lack of water, food, and shelter, and reduction in annual output of eggs in response to drought. We review these subjects below (Morafka and Berry 2002).

The Tortoise Burrow. - Tortoises spend $>90 \%$ of their lives inactive and underground in burrows, pallets, caves, or other cover. For example, in the northern part of the range in Rock Valley, Nevada, where numbers of freezing days/year are high,Nagy and Medica (1986) reported that tortoises spent $98.3 \%$ of time underground. We define pallets as scrapes, often under a shrub, potentially the beginning ofa burrow, covering only part of the shell; they are often used in spring as a temporary refuge. Burrows are dug in soil, are often 3 $\mathrm{m}$ or more in length with a soil cover of a meter or more in the deepest part, and have a downward slope. Dens occur in areas with well-developed calcic layers, are often in washes, the tunnels are generally horizontal and may have side rooms and chambers that can be used by multiple tortoises. Caves are similar to dens, larger than the tortoise, with an arched roof, and are not the size and shape of a tortoise. Use of burrows and dens allows tortoises to shelter during times of extreme temperatures and when there is a lack of water and food, and when in a deep burrow, tortoises reduce their metabolic rates (Henen et al. 1998).

Types of cover site or shelter (pallet, burrow, cave, den) differ throughout the geographic range and depend on topography, geology, and soil types as well as seasons (Woodbury and Hardy 1948; Bulova 1994; Berry et al. 2006). Regardless of type of cave or burrow, the opening for adult sites is half-moon shaped, curved side up, unless it has been altered by another species of animal (Woodbury and Hardy 1948). Wild juvenile and small immature tortoises also use small, half-moon shaped burrows matching their sizes at several Mojave and western Sonoran Desert sites (Berry and Turner 1986). In a study of head-started tortoises, most neonates $(83 \%)$ hatched in pens constructed their own burrows within a few days of emergence from the nest; others used rodent burrows or shared artificial burrows constructed for adults (Morafka et al. 1997).

In the northern part of the range, caves and dens in the walls of ephemeral stream beds are more common than elsewhere. They occur in old alluvial deposits with consolidated gravels and sand and with well-developed calcite cementation (Woodbury and Hardy 1948; Mack et al.2015). These retreats can be several meters in length and used by multiple tortoises. In the northeastern Mojave Desert, caves or dens were usually 2.4 to $4.6 \mathrm{~m}$ in length, occasionally 6.1 to $9.1 \mathrm{~m}$ with multiple side tunnels and rooms supporting as many as 17 tortoises simultaneously (Woodbury and Hardy 1948). Tortoises can use a combination of burrows, caves, and dens (Woodbury and Hardy 1948; Mack et al. 2015). In contrast, in the northwestern, western, and southern Mojave and Colorado deserts, tortoises primarily use burrows (Berry et al. 2006, 2013, 2014; Krzysik 2002; Harless et al. 2009).

Most cover sites were found beneath the canopies of large shrubs, regardless of size of the tortoise (Burge 1978; Berry and Turner 1986). At the Arden site in Nevada, Burge (1978) reported that $72 \%$ of large and small burrows were placed under shrubs with the greatest shade-giving properties (i.e., catclaw, Senegalia greggii [Acacia greggii], Mojave yucca and creosote bush). For wild juveniles and small immature tortoises, $79 \%$ of burrows were under canopies or basal branches of live or dead shrubs; creosote and white bur-sage were the most common species (Berry and Turner 1986). 
The burrows of head-started juvenile tortoises in pens also were under the canopies of shrubs (Wilson et al. 1999a).

Tortoises use more than one burrow or cave per season or year (Woodbury and Hardy 1948; Burge 1978; Bulova 1994; Harless et al. 2009). The patterns of shelter type and tunnel length varied by season (Woodbury and Hardy 1948; Rautenstrauch et al. 2002), with tortoises tending to use shallower sites in spring and deeper and longer tunnels in fall and winter. Tortoises exhibited fidelity to specific burrows, repeatedly returning to burrows used from season to season (Burge 1978). If the burrow was damaged or collapsed, the tortoise would either rehabilitate it or construct another burrow adjacent to the collapsed burrow. Freilich et al. (2000) reported fidelity to the vicinity of a site, rather than to a specific burrow (i.e., $75 \%$ of all captures were within $300 \mathrm{~m}$ of a previous location). Woodbury and Hardy (1948) noted that tortoises tend to stay in familiar areas.

Tortoise dens, caves, and burrows are potentially important as home sites and temporary refuges from extremes of temperature or predation for many species of vertebrates and invertebrates. Woodbury and Hardy (1948) physically entered dens occasionally and thus were able to learn more about commensals and predators than the incidental observations reported more recently by others. We do not know the extent of use by commensals or transients. However, the following compiled list, while not comprehensive and excluding invertebrates, suggests that burrows, dens, and caves occupied by tortoises are critically important to desert ecosystems. They are shared by many other vertebrates, including mammals, birds, and reptiles.

Lizards observed in burrows or dens include the Gila Monster, Heloderma suspectum (Gienger and Tracy 2008), Desert Spiny Lizard (Sceloporus magister), Long-nosed Leopard Lizard (Gambelia wislizenii), and Desert Banded Gecko (Coleonyx variegatus) (Woodbury and Hardy 1948; Walde and Currylow 2015; Walde et al. 2015; Agha et al. 2017). Snakes observed in burrows or dens include the Spotted Night Snake (Hypsiglena torquata), Coachwhip (Masticophis flagellum), and five species of Rattlesnake: Sidewinder (Crotalus cerastes), Great Basin (C. oreganus lutosus), Red Diamond (C.ruber), Speckled (C. mitchellii), and Mojave (C. scutulatus) (Woodbury and Hardy 1948; Burge 1978; Lovich 2011; Walde etal.2014; Agha et al.2017; Berry et al., pers. obs.). Birds observed in dens or burrows include the Burrowing Owl (Athene cunicularia), Cactus Wren (Campylorhynchus brunneicapillus), Roadrunner (Geococcyx californianus), and Horned Lark (Eremophila alpestris) (Woodbury and Hardy 1948; Burge, 1978; Walde et al. 2009; Agha et al. 2017). Mammals observed were the Desert Woodrat (Neotoma lepida), Merriam's Kangaroo Rat (Dipodomys merriami), White-footed Mouse (Peromyscus spp.), Antelope Ground Squirrel (Ammospermophilus leucurus), Desert Cottontail (Sylvilagus audubonii), and
Black-tailed Jackrabbit (Lepus californicus) (Woodbury and Hardy 1948; Burge 1978; Agha et al. 2017), as well as Desert Kit Fox (Vulpes macrotis; Berry, pers. obs.) and American Badger (Taxidea taxus) (Germano and Perry 2012).

In a camera study of tortoise burrows in the western Colorado Desert, Agha et al. (2017) substantially added to the list of vertebrates observed in or near the entrances of tortoise burrows with several additional species of mammals, birds, and reptiles. Excluding large vertebrates (e.g., Bighorn Sheep, Black Bears), additional mammals seen were Desert Kangaroo Rat (Dipodomys deserti), Desert Pocket Mouse (Chaetodipus penicillatus), and California Ground Squirrel (Otospermophilus beecheyi). Additional birds seen were Rock Wren (Salpinctes obsoletus), California Towhee (Melozone crissalis), Black-throated Sparrow (Amphispiza bilineata),Loggerhead Shrike (Lanius ludovicianus), Chukar Partridge (Alectoris chukar), Bewick's Wren (Thryomanes bewickii), California Quail (Callipepla californica), Whitecrowned Sparrow (Zonotrichia leucophrys), California Thrasher (Toxostoma redivivum), Common Raven (Corvus corax), and Verdin (Auriparus flaviceps). Additional reptiles seen were Great Basin Whiptail (Aspidoscelis tigris tigris), Western Side-blotched Lizard (Uta stansburiana), Sagebrush Lizard (Sceloporus graciosus), and Long-nosed Snake (Rhinocheilus lecontei).

Seasonal and Daily Activities. - Ambient temperatures above and below ground are an important factor in determining activity, but not the only factor. Tortoises primarily regulate body temperature by behavior, avoiding excess heat and cold by retreating to burrows, pallets, and dens. Early studies indicated that body temperatures of active tortoises were between 19.0 and $37.8^{\circ} \mathrm{C}$, and that tortoises retreated to shade at $37-38^{\circ} \mathrm{C}$; the critical thermal maximum of internal body temperatures was between 39.5 and $43.0^{\circ} \mathrm{C}$, and the lethal maximum was $43.0^{\circ} \mathrm{C}$ (Brattstrom 1961, 1965). At the lower limit of the lethal range $\left(39.5^{\circ} \mathrm{C}\right)$, a tortoise will produce copious amounts of saliva, which spread along the neck and axillary area in an effort at cooling (McGinnis and Voigt 1971).

Temperatures inside burrows and dens are cooler than on the mound or outside. Year-round temperatures $5.3 \mathrm{~m}$ inside deep dens on the Beaver Dam Slope of Utah (northeastern Mojave Desert) were between 10.0 to $15.6^{\circ} \mathrm{C}$ (Woodbury and Hardy 1948). In a study in the central Mojave Desert, Mack et al. (2015) compared annual temperatures under shrubs, and at the entrance to and inside caves and burrows dug in soils. Average maximum summer and winter temperatures ca. $1.5 \mathrm{~m}$ inside 24 caves were $33.7^{\circ} \mathrm{C}\left(\right.$ range $\left.=29.2-38.3^{\circ} \mathrm{C}\right)$ and $13.5^{\circ} \mathrm{C}$, respectively. They did not place temperature probes as deeply as Woodbury and Hardy (1948) did to avoid disturbing the tortoises. Tunnel length had the greatest influence on temperatures: they were warmer in winter and cooler in summer compared to outside the burrow or cave 
(Mack et al. 2015). Cover sites in consolidated gravels and soils were warmer than caves in summer, but not significantly cooler in winter.

The microhabitats of burrows and dens and length of tunnels affected humidity and thus water loss (Bulova 2002). Longer burrows with smaller entries tended to be cooler and more humid. Wilson et al. (2001) showed experimentally that hibernating juveniles lost body mass $1 / 20$ th as quickly as active juveniles. Juveniles in shorter burrows in the field lost body mass faster than those in the longer tunnels.

Time spent underground or in above-ground activities differed by year, individual, sex, size, and region (e.g.,Berry and Turner 1986; Zimmerman et al. 1994; Rautenstrauch et al. 1998; Nussear et al.2007; Agha et al.2015a). All seasonal and daily activities were influenced by temperature tolerances of tortoises, temperature extremes in the environment, timing and amounts of precipitation, availability of free water to drink, and available forage (Woodbury and Hardy 1948; Brattstrom 1961; Nagy and Medica 1986; Zimmerman et al. 1994; Henen et al. 1998; Rautenstrauch et al. 1998).

The general pattern for seasonal activity involved emergence from hibernation or brumation in late winter or early spring, followed by above-ground foraging (when forage was available) and interacting with other tortoises, and by retreat to burrows, pallets, dens, and rock shelters in late spring, with occasional emergence during summer in June and July early in the day or late in the evening. Starting in August and September, tortoises emerged for short periods and traveled; they were active intermittently until mid- to late October or November, when they retreated underground for hibernation (Woodbury and Hardy 1948; Rautenstrauch et al. 2002). However, tortoises sometimes emerged from underground retreats to drink free water and change shelter sites at any time of year; they were especially likely to emerge with rainfall events during or after droughts (Medica et al. 1980; Henen et al. 1998). Males tended to be more active than females (Agha et al. 2015a).

Surface and air temperatures affected daily and seasonal emergence from and retreat to burrows for adult tortoises (Woodbury and Hardy 1948; McGinnis and Voigt 1971; Zimmerman et al. 1994). In late winter and early spring, tortoises sometimes emerged mid-morning and were active until late afternoon. However, from spring until October or November, above-ground activity became bimodal, with tortoises emerging earlier in the morning from burrows and retreating earlier to burrows, emerging again in afternoon or evening. In summer, some tortoises emerged in late afternoon or evening and remained above ground all night when burrow temperatures were warmer than the outside surface temperatures. However, not all tortoises emerge once or twice daily during the active seasons.

Small wild juvenile tortoises of $<60 \mathrm{~mm}$ CL were observed to be active at significantly lower temperatures in
March, April, May, and June than larger juveniles and small immature tortoises regardless of the month of observation in spring, e.g., $17.2^{\circ} \mathrm{C}$ (range 10.1-25.6 ${ }^{\circ}$ in March (Berry and Turner 1986). Some head-started juveniles in pens were also active in winter (Wilson et al. 1999b). The small size and ability to be active at cold temperatures may have allowed small tortoises to be active on more days per season and year than observed for adults.

Rainfall, available water for drinking, and available, high quality forage strongly influenced seasonal and daily activities. In years when precipitation was above the long-term normal for the season and forage was plentiful or otherwise available, tortoises were more active above ground than during droughts (Henen et al. 1998; Duda et al. 1999; Freilich et al. 2000; Krzysik 2002; Jennings and Berry 2015). During drought years, home range size, numbers of burrows used, and distances traveled per day decreased substantially.

Physiology, Water Balance, and Energy Flow. - Thermoregulation, water balance and osmoregulation, metabolism, and responses to drought (deprivation of water and food) are critical to survival of tortoises in harsh environments. Henen et al. (1998) summarized several years of study concerning the effects of climate, specifically variation in rainfall and food availability, on metabolic rates and water flux rates in adult tortoises in western, eastern, and northeastern regions of the Mojave Desert. Availability of water (and forage) varied substantially from year to year and thus affected metabolic rates. Water flux-rates and availability of free water for drinking also varied highly. In years of high rainfall, metabolic rates and water flux-rates were higher than in dry years. Metabolic rates in males were higher than in females, possibly because of larger home ranges and courting females. In contrast, the annual field metabolic rate of females correlated positively with the number of eggs laid in spring. During droughts when forage and water were unavailable, metabolic rates and water influx rates were low. While some variations were due to season, rainfall was the critical factor in rates of metabolism and rates of water influx. Differences in region were due to differences in rainfall and with more summer rainfall occurring at the eastern and northeastern sites in the Mojave Desert. Overall, the results indicated that tortoises have both physiological and behavioral flexibilities critical to surviving droughts and periods of rainfall and food abundance.

Another important adaptation to drought and variability in rainfall involves drinking free water during rain, voiding their bladders, and rapidly increasing their mass (Peterson 1996). When droughts occur, tortoises can lose up to $40 \%$ of initial body mass. They can resorb water from their bladders and store wastes (sodium, chloride, and urea) both in blood plasma and the bladder. 


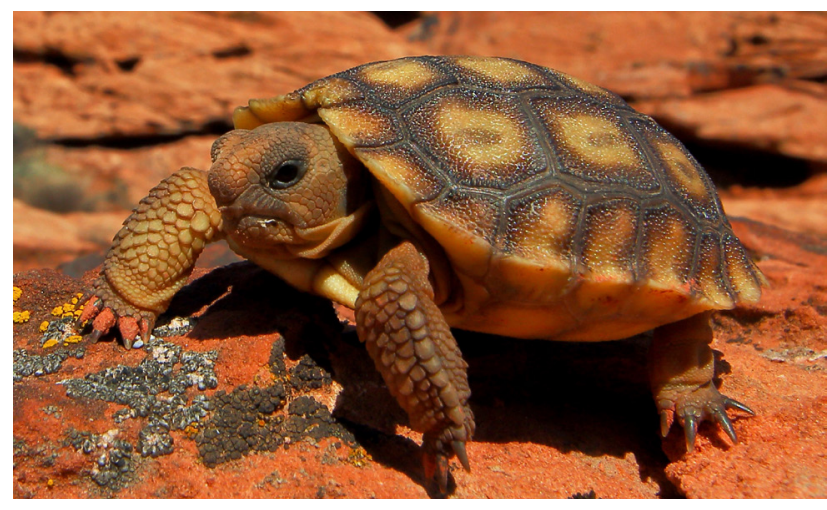

Figure 9. Juvenile Gopherus agassizii eating lichen in the Red Cliffs Desert Reserve, Utah. Photo by Cameron Rognan.

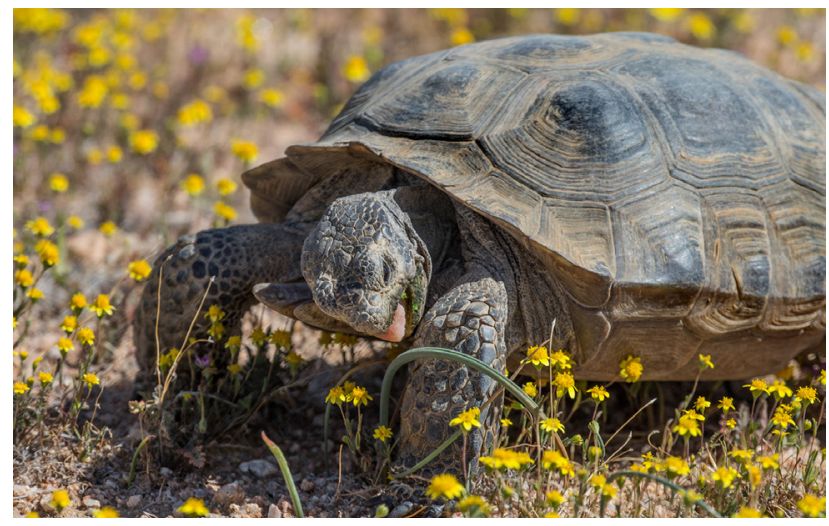

Figure 10. Adult Gopherus agassizii eating blue dicks (Dichelostemma apitatum) in the Western Mojave Recovery Unit. Photo courtesy of Desert Tortoise Preserve Committee.

Tortoises may also void their bladders when handled or when approached by a human. Agha et al. (2015b), in a study of 42 tortoises captured 1008 times in the western Sonoran Desert, found that tortoises voided on $8.2 \%$ of occasions. Factors contributing to higher probabilities of voiding were increased handling time regardless of size or sex and increased precipitation for juveniles and females. Models indicated a negligible effect of voiding behavior and sex on survivorship.

Christopher et al. (1999) reported seasonal differences in hematologic and plasma biochemical responses of adult tortoises in a five-year study in three Mojave Desert regions (western, eastern, northeastern). The authors reported yearly and seasonal variation in most variables associated with hibernation, the reproductive cycle, and seasonal rainfall. The effects of water and food intake were reflected in body weight and biochemical changes in blood plasma (decreased blood urea nitrogen [BUN] and increased uric acid), nutrient intake (increased concentrations of glucose, total protein, albumin, phosphorus, cholesterol, iron, and potassium concentrations), and increased metabolic activity (increased alkaline phosphatase, aspartate aminotransferase, alanine aminotransferase activities). The most sensitive indicator of food and water intake or lack was BUN. Seasonal changes, particularly during the dry summer or fall, were typical of decreased hydration: increased BUN, osmolality,electrolytes, and anion gap, and decreased body weight and total $\mathrm{CO}_{2}$. Males and females differed in packed cell volume, aspartate transaminase activity, and concentrations of hemoglobin, cholesterol, triglycerides, calcium, and phosphorus.

Wild tortoises that were moribund from dehydration and starvation during or following droughts exhibited clinical signs, such as weight loss and abnormal behaviors (Berry et al. 2002). These tortoises also exceeded the range or 95th percentiles for four or more hematological and plasma biochemical analytes for healthy tortoises (Christopher et al. 1999). Hematologic abnormalities were low packed cell volumes and heterophil counts, and plasma biochemical analytes were hypocalcemia, hyperbilirubinemia, marked azotemia, and elevated sodium and chloride (Berry et al. 2002). Gross necropsies revealed differences in juveniles vs. the larger tortoises. Shells of juveniles were softer and more pliable, muscle mass was below normal, and osteopenia of some bones was evident. Handling and certain research activities also had detrimental effects, such as crowding of juveniles in headstart pens.

Foraging Behavior and Diet. - Early field studies revealed that tortoises were herbivorous, foraged in spring and fall when food was plentiful, and consumed dry grass in summer (Woodbury and Hardy 1948). Grasses were the native bush muhly (Muhlenbergia porteri) and the non-native red brome and cheat grass (Bromus madritensis ssp. rubens and $B$. tectorum); the non-native redstem filaree (Erodium cicutarium) was observed to be eaten in winter.During spring, tortoise ate wildflowers until domestic sheep herds reduced availability. Field biologists have not observed tortoises to eat shrubs (Woodbury and Hardy 1948; Nagy and Medica 1986).

The need to know what tortoises were eating in greater detail came with concerns about conflicts between livestock grazing and tortoises and federal listing of the tortoise population on the Beaver Dam Slope (Berry 1978; USFWS 1980). This conflict over food availability in spring was first described by Woodbury and Hardy (1948) and was later observed and studied elsewhere in the Mojave Desert (Berry 1978; Avery and Neibergs 1997; Oftedal 2002; Oftedal et al. 2002; Jennings and Berry 2015).

Tortoises are selective in choice of food items, when conditions allow for it. In Rock Valley, Nevada, tortoises kept in large pens ate only four of $>25$ species of forbs and grasses available (Nagy and Medica 1986). Burge and Bradley (1976) observed foraging behavior of wild tortoises in late winter and spring and reported on species and plant parts eaten. Subsequent research involved counting every bite taken as well as plant parts and species available (e.g., Avery and Neibergs 1997; Henen 2002a; Oftedal et al. 2002; Jennings and Berry 2015). Results indicated that tortoises select species and plant parts, and that favored species differed 
by season, region, and availability. In late winter and spring of a highly productive year, tortoises prefer natives to nonnatives, forbs to grasses, and succulent green plants to dry plants. Choices of plant species tracked the phenology of species available during spring (Jennings and Berry 2015). In drought years when species and biomass of plants were limited, some tortoises consumed cacti (Turner et al. 1984).

The list of plant groups eaten included winter and summer annuals, a few herbaceous perennials, succulents (cacti), and flowers and leaves of a few perennial shrubs. Tortoises favored species of forbs or herbaceous perennials from several plant families: Asteraceae, Boraginaceae, Cactaceae, Fabaceae, Malvaceae, Nyctaginaceae, Onagraceae, and Plantaginaceae (Burge and Bradley 1976; Avery and Neibergs 1997; Jennings and Berry 2015).

Oftedal (2002) and Oftedal et al. (2002) addressed why tortoises were selective in choices of plants and developed the concept of potassium excretion potential (PEP). Many plant species are high in potassium which requires loss of water and nitrogen to excrete; potassium is potentially toxic. The authors predicted that tortoises would choose plants high in water and protein but low in potassium. In a study of plants consumed or by-passed by juveniles in head-start pens during a year of high rainfall and thus abundant forbs, juveniles selected plants and plant parts high in water and nitrogen and low in potassium (Oftedal et al. 2002). The juveniles bypassed the abundant non-native Mediterranean grasses, Schismus spp.

Non-native forbs (e.g., redstem filaree) and grasses (Mediterranean grasses, red brome, and cheat grass) invaded and became established throughout the Mojave Desert and form $>60 \%$ of the biomass in years with above normal precipitation and $>90 \%$ in drought years in tortoise critical habitat units in the western, central and southern regions of the Mojave Desert (Brooks and Berry 2006). Other nonnative species, such as Sahara or African mustard (Brassica tournefortii), invaded and proliferated rapidly in the western Sonoran Desert and appear to be displacing native annual forbs (Berry et al. 2014b).

The nutrient value of native vs. non-native forbs and grasses was the subject of several experiments with tortoises in a range of sizes (Nagy et al. 1998; Hazard et al. 2009, 2010). In the experiments, the forb species were the native Malacothrix glabrata and non-native redstem filaree, and the grasses were the native and perennial sand rice grass (Stipa [Oryzopsis] hymenoides) and non-native annual Mediterranean grasses (Schismus barbatus). The forbs were higher in dry matter and energy digestibilities than the grasses. The grasses provided little nitrogen and tortoises lost more water than they gained in processing them. Hazard et al. (2009) reported that juveniles gained weight rapidly when eating forbs but lost weight and body nitrogen when eating grasses. Dietary nitrogen might have limited growth of juveniles. Tortoises gained more minerals from forbs than from grasses (Hazard et al. 2010). When eating grasses, the tortoises lost phosphorus and only gained the nutrients calcium and magnesium at low rates.

In several experiments, individual tortoises did not thrive or became ill when fed grasses (Hazard et al. 2009, 2010). Two animals offered the non-native Mediterranean grasses became ill and died early in the study and two others refused to eat. Drake et al. (2016) tested effects of five diets - native forbs, native six weeks grass (Festuca octoflora), invasive red brome grass, and native forbs combined with either native or invasive grass - on growth, body condition, immunological responses, and survival on 100 captive neonate and juvenile tortoises. Tortoises fed native forbs had better body condition, growth, immune functions, and higher survival $(>95 \%)$ than those fed the grass diets.About one-third of tortoises fed only grass diets died or were removed for poor condition. Tortoises fed the mixed forb and grass diet survived and were in good condition. In addition, tortoises consuming red brome were observed with persisting injuries to their jaws from seeds, and seeds were also embedded in a nostril and corner of an eye (Medica and Eckert 2007). Drake et al. (2016) made similar observations and noted inflammation. Collectively, these studies point out the importance of selected native forbs to the health and overall condition of tortoises. Tortoises also consume non-plant material: dirt and sand at apparent salt licks, rocks, bone, dead lizards, and caterpillars (Marlow and Tollestrup 1982; Avery and Neibergs 1997; Walde et al. 2007a; Jennings and Berry 2015).

Home Range, Site Fidelity, and Movements. - Sizes of home ranges for wild, free-ranging tortoises varied by type and length of study, sample sizes, sex, numbers of captures, location, and analytical techniques (e.g., Woodbury and Hardy 1948; O'Connor et al. 1994; Duda et al. 1999; Freilich et al. 2000; McLuckie and Fridell 2002; Harless et al. 2009, 2010; Franks et al. 2011). Most reports were for wild, free-living adult tortoises, involved small samples, and were confined to a few years. Woodbury and Hardy (1948) reported that home ranges were small, covering ca. 4 to 40 ha.

In studies where sizes of home range for both male and female adult tortoises were derived from radio-transmittered individuals, males had larger home ranges than females (Burge 1977a; O'Connor et al. 1994; Duda et al. 1999; Freilich et al.2000; Harless et al.2009). Forexample, Harless et al. (2009), in a study of home range and movements in the central Mojave Desert, described home range sizes of $43-49$ ha for males and $16-17$ ha for females using minimum convex polygons. Home ranges of juveniles were smaller than those of adults (Eric Coombs, unpubl. data).

Home range sizes potentially increased in wet vs. dry years (Burge 1977a; Duda et al. 1999; Franks et al. 2011). Similarly, movements were more limited during drought years than in years with higher precipitation and forage 
production, e.g., years with El Niño Southern Oscillation (Duda et al. 1999; Freilich et al. 2000; Ennen et al. 2012). O'Connor et al. (1994) noted that home ranges were not exclusive for individuals, in contrast to a study by Harless et al.(2009), who reported that home ranges of males overlapped but those of females did not. Tortoises exhibited fidelity to home ranges and activity areas; even after a fire when parts of home ranges were burned, tortoises continued to use the same areas (Drake et al. 2015; Lovich et al. 2018a).

Female Reproductive Cycle. - Female and male reproductive cycles are not synchronized (Rostal et al. 1994; Lance and Rostal 2002). In April, after emergence from hibernation, plasma estradiol, testosterone, corticosterone, and lipids in females were elevated but declined to low levels after eggs were laid. When nesting occurred in spring, progesterone levels increased, but rapidly decreased to baseline after eggs were laid. In summer, plasma levels of estradiol, lipids, and calcium (indicating vitellogenin levels) increased and were associated with vitellogenesis and growth of ovarian follicles. Ovarian follicles increased to ovulatory size before hibernation. Testosterone levels were high (mean $6.22 \mathrm{ng} / \mathrm{mL}$ ) during spring courtship (April), declining to a mean of $0.37 \mathrm{ng} / \mathrm{mL}$ at the end of the nesting period (July), but again rose between July and October during the late summer and fall courtship and mating period.

Size and age at first reproduction vary across the geographic range. However, long-term studies have not been conducted for wild, free-ranging female tortoises for all regions. Woodbury and Hardy (1948) estimated age at first reproduction as 15-20 years in the northeastern Mojave Desert, whereas Turner et al. (1987) estimated 12 to 20 years for females in the eastern Mojave Desert, drawing on a multiyear study to develop a life table for the species. Curtin et al. (2009), in a study based on skeletochronology, estimated that females from the western Mojave Desert reached sexual maturity at 17-19 years. Medica et al. (2012), in a 47-year study of tortoises in 9-ha pens in the northeastern Mojave Desert, estimated sexual maturity to occur between 16 and 21 years (average 18.8 years) and at a minimum size of about $190 \mathrm{~mm}$ CL. Turner et al. (1987) treated size at first reproduction as $185 \mathrm{~mm} \mathrm{CL}$; they reported a female with eggs at $178 \mathrm{~mm}$ CL but four other small females (182-186 $\mathrm{mm} \mathrm{CL}$ ) did not produce eggs. In the far northern part of the range in Nevada, the smallest tortoise to produce eggs was $209 \mathrm{~mm}$ CL; 11 smaller tortoises estimated to be 15-26 years old did not produce eggs (Mueller et al. 1998). Generation time for G. agassizii has been estimated to be approximately 20-25 years (Turner et al. 1987; USFWS 1994), but this appears to need revision upwards based on the late age of maturity and high survivorship and longevity of adults.

Females place nests within the den or burrow, on the burrow mound, in a pallet, and under shrubs (Woodbury and Hardy 1948; Roberson et al. 1985; Turner et al. 1986;
Baxter et al. 2008; Ennen et al. 2012; Lovich et al. 2014a; Sieg et al. 2015). Females dig nests within their normal activity areas but show no evidence of fidelity within or between seasons regarding locations (Lovich et al. 2014a). Oviposition occurs from April through July, depending on region, for first, second, and third clutches (Turner et al. 1986, 1987; Wallis et al. 1999; McLuckie and Fridell 2002; Ennen et al. 2012; Lovich et al. 2018a). Nesting may occur earlier in the western Sonoran Desert - Lovichet al. (2018a) noted nesting April 6 at a study site in Joshua Tree National Park, two weeks earlier than published previously. Lovich et al. (2012) also described how the timing and appearance of shelled eggs on X-rays appeared to be affected by interannual variations in climate, e.g., appearance of clutches was later in cool years.

Some females showed nest-guarding behaviors to Gila Monsters and humans (Henen 1999; Gienger and Tracy 2008; Agha et al. 2013). Beck (1990) studied Gila Monsters in southwestern Utah; $29 \%$ of their scats and observations were of predation on tortoise nests. Gienger and Tracy (2008) reported two different observations of Gila Monsters entering shelters with a female tortoise and egg shell fragments later observed at the nest. In one case, the female tortoise bit and chased the lizard. Henen (1999) reported that a $182 \mathrm{~mm}$ CL female rammed his leg and field equipment with her epiplastron a few days after laying her first clutch of eggs. In another case report, Agha et al. (2013) described a female tortoise twice resisting a researcher's attempts to remove her from her burrow, which contained a nest.

Few reports are available for incubation of eggs in wild, unconfined, or unprotected settings. Eggs of one wild female hatched after 98-101 days in southern Nevada (Burge 1977b) and of 12 wild females after 67-104 days with a mean incubation time of 89.7 days ( \pm 3.25 days SE) in southwestern Utah (McLuckie and Fridell 2002). Ennen et al. (2012) reported hatching from 74 to 100 days (mean, 84.6 days) at a site in the western Sonoran Desert. Incubation time was significantly longer in the first than in second clutches. Nest predation occurred commonly (Roberson et al. 1985; Turner et al. 1986; Ennen et al.2012). Nests placed in cages to prevent predation may have hatched between 84 and 97 days in the eastern Mojave Desert (Roberson et al. 1985).

Dimensions and weights of eggs may vary by year, site, and whether measured directly or from radiographs. Measurements from radiographs may underestimate egg sizes slightly (Wallis et al. 1999). Burge (1977b) reported dimensions of four eggs from tortoises at Arden, Nevada $(43.0 \times 33.0$, $45.0 \times 36.0,46.0 \times 33.0,47.0 \times 34.0 \mathrm{~mm})$. Using X-rays to measure eggs, Wallis et al. (1999) described egg sizes for first and second clutches and for two different years at Goffs $(n=137)$ in the eastern Mojave Desert and at the Desert Tortoise Research Natural Area $(n=330)$ in the western 
Mojave Desert. Eggs from Goffs were generally about 40.9 $\mathrm{mm}$ in length and $34 \mathrm{~mm}$ in width, whereas those from the Desert Tortoise Research Natural Area females were about $45 \mathrm{~mm}$ in length and $37 \mathrm{~mm}$ in width. McLuckie and Fridell (2002) reported sizes of 81 eggs as having a mean length of $44.3 \pm 0.33 \mathrm{~mm} \mathrm{SE}$ (range 34-52) and mean width of 37.2 $\pm 0.26 \mathrm{~mm} \mathrm{SE}$ (range 33-43) for tortoises from the Beaver Dam Slope, Utah. Ennen et al. (2012) reported mean width of eggs as $38.6 \mathrm{~mm}$ at a study area in the western Colorado Desert, and Lovich et al. (2018b) reported average x-ray egg widths of $36.5 \pm 1.56 \mathrm{~mm}$ from a study area in Joshua Tree National Park, also in the Colorado Desert.

Site and body size of females can affect egg shape. In a comparative study of females from the western Mojave Desert in the Desert Tortoise Research Natural Area with females from the eastern Mojave Desert, the eastern females produced eggs that were significantly narrower and shorter than females from the western site, even after accounting for body sizes (Wallis et al. 1999).

The numbers of eggs laid per clutch range from 1 to 10 , with females laying from 0 to 3 clutches per year (Turner et al. 1986; Mueller et al. 1998; McLuckie and Fridell 2002; Lovich et al. 2015). Studies undertaken at different sites and years described mean clutch sizes ranging from 3.25 to 5.91 eggs and clutch frequencies from 1.33 to 2.36 clutches/ female/year (Turner et al. 1986; Mueller et al. 1998; Wallis et al. 1999; McLuckie and Fridell 2002; Bjurlin and Bissonette 2004; Baxter et al.2008; Lovich et al.2015,2018b). At some sites, researchers reported that larger females produced larger clutches (Turner et al. 1986; Wallis et al. 1999; McLuckie and Fridell 2002) and females producing a single clutch laid larger eggs (Turner et al. 1986; Mueller et al. 1998). Clutch frequencies were correlated positively with carapace length (McLuckie and Fridell 2002), and annual fecundity was positively correlated with female size (Mueller et al. 1998; Wallis et al. 1999; McLuckie and Fridell 2002). Wallis et al. (1999) observed females at a western Mojave Desert site that produced fewer but larger eggs than females at an eastern Mojave site, and Sieg et al.(2015) reported that larger females produced larger eggs, but carapace length did not affect clutch size.

Timing and amounts of rainfall and the subsequent production of forbs and grasses consumed by tortoises likely affect one or more aspects of egg production and the effects may differ regionally. For example, precipitation occurred primarily in late fall and winter in the western Mojave Desert compared with precipitation occurring both in fall-winter and summer in the eastern Mojave (Turner et al.1986). Environmental conditions in the previous year may affect egg production in a subsequent year, because ovarian follicles mature between July and October and the number maturing is dependent on available food and water (Henen 1997; Mueller et al. 1998). Henen (1997) also reported that the commitment of energy to eggs does not occur until the spring in which they are laid.

At a western Mojave location, females produced larger eggs, possibly increasing the chance of survival because of lack of summer rain (Wallis et al. 1999). In contrast, in the eastern Mojave Desert, eggs were smaller, possibly allowing the juveniles to take advantage of the summer rains and associated food sources. Also, in the eastern Mojave Desert, clutch frequencies were positively correlated with production of annual forbs and grasses (Turner et al. 1986), and Henen (1997) described how the paucity of spring annual plants contributed to lower egg production.

In the Colorado Desert, Lovich et al. (2015) reported that amounts of winter precipitation had no significant effect on clutch frequency or the percentage of reproducing females. Sieg et al. (2015) reported elevation to be a factor in a study of two sites in the northeastern Mojave Desert; females had larger egg volumes in first clutches at the higher elevation site than females at the lower elevation site. At the higher elevation site, precipitation was higher and values for species richness of shrubs, total cover of plants, and herbaceous plant biomass were all higher than at lower elevations.

Females appeared to use a breeding strategy intermediate between capital and income breeding with bet hedging (Henen 2002a, 2002b, 2004; Lovich et al. 2015). Desert Tortoises have shown the ability to relax or temporarily relinquish regulation of homeostasis regarding water, electrolytes, nitrogen, and energy. In field studies, females demonstrated extreme physiological tolerance and flexibility in their water and energy budgets (Henen 2002a). They reduced metabolic rates and produced eggs, even during periods of extreme droughts and lack of forage (Henen 2002b). Females exhibited characteristics of both capital and income breeders: they limited egg production during droughts and when body reserves were limited, acquired water and protein reserves prior to winter and used reserves to produce eggs, had full-sized follicles prior to hibernation, and ovulated prior to eating in spring (Henen 2002 b). They also responded rapidly by producing more eggs when forage became available after hibernation. This mixed strategy constituted bet-hedging for reproducing in the extremes typical of desert environments. Lovich et al. (2015) provided an additional example with a study population in the western Sonoran Desert.

Turner et al. (1987), drawing on a multi-year study in the eastern Mojave Desert of egg production and nest successes, estimated that $93.9 \%$ of eggs were fertile, $93.4 \%$ were unbroken, and $62.9 \%$ were not destroyed by predators. Bjurlin and Bissonette (2004) described tracking success of 17 and 25 nests laid in 1998 and 1999, respectively, at a site in the southern Mojave Desert. Predation rates were high in 1998 (47\% of nests), but less so in 1999 (12\% of nests). The authors then protected nests with cages 70 days 
after incubation. Of the remaining 132 caged eggs, $81.6 \%$ and $83.0 \%$ hatched in 1998 and 1999, respectively. When ill and deformed neonates were excluded, the figures for normal neonates were $73.7 \%$ and $67.0 \%$ in 1998 and 1999, respectively. Ennen et al. (2012) described mean hatchling success (predation included) as $70.6 \%$ for the first clutch and $65.7 \%$ for the second clutch. Some eggs did not hatch, were infertile or nonviable, and a few hatchlings were ill or deformed in several studies (e.g., Turner et al. 1986; Bjurlin and Bissonette 2004; Ennen et al. 2012).

The sex of neonates was determined by temperatures during incubation in the nest (Rostal et al. 2002). In experiments, males were produced when incubation occurred at constant temperatures of $\leq 30.5^{\circ} \mathrm{C}$, whereas females were produced at temperatures of $\geq 32.5^{\circ} \mathrm{C}$. The pivotal temperature where sexes were in a $1: 1$ ratio was $31.3^{\circ} \mathrm{C}$. Hatching success was high (90-100\%) when temperatures ranged from 28 to $34^{\circ} \mathrm{C}$ and resulted in similar incubation times ranging from 68 to 89 days. When temperatures were lower or higher, survival was lower. Baxter et al. (2008), in a study of females in a head-starting enclosure in the central Mojave Desert, reported that early nests (22 May-2 June) were cooler and produced four all-male nests and two nests of mixed sexes. In contrast, six later nests (17 June-16 July) were significantly warmer and produced only females.

Adult female tortoises store sperm, potentially in the sperm-storage tubules within the albumen-secreting gland region of the oviduct (Palmer et al.1998). In an experimental study, hatching success was $97.1 \%$ in females with sperm stored $>2$ years. Five of 12 clutches showed tentative evidence of multiple paternities. Davy et al. (2011) confirmed both polyandry and multiple paternities in clutches from females: of 28 clutches from 26 females with an average of six neonates per clutch, a minimum of $64 \%$ of females were polyandrous and a minimum of $57 \%$ of clutches had multiple sires.

Male Reproductive Cycle. - Testosterone primarily controls changes in the male cycle (Rostal et al. 1994; Lance and Rostal 2002). Testosterone levels were low when males emerged from hibernation and continued to decline until May, but then rose from late May to August and September, reaching a peak at a mean of $243.60 \mathrm{ng} / \mathrm{mL}$, and then declined prior to hibernation. The low in testosterone levels (mean $18.37 \mathrm{ng} / \mathrm{mL}$ ) occurred when females were nesting in May. Changes in the testes followed this cycle: when males emerged from hibernation, the seminiferous tubules were filled with debris from the previous cycle and by May the gonads were completely regressed. As summer progressed, mature spermatozoa appeared, and prior to hibernation in early fall, spermatogenesis was at a maximal level. Corticosterone levels were high when testosterone was high but higher than in females at any time of year. Body mass tracked these changes and was significantly higher from June to September than at other times during the year. The fall mating period may be more important than courtship activity in spring and may be associated with sperm storage in females (Palmer et al. 1998).

Table 2. Demographic data from early surveys of populations of Gopherus agassizii, primarily from 60 -day spring studies on $2.59 \mathrm{~km}^{2}$ plots in California, Nevada, Utah, and Arizona. Adults are defined as $\geq 180 \mathrm{~mm}$ carapace length. For most plots, data were summarized in Berry (1984), a compilation of plot data from 1948 through 1981. The population at Beaver Dam Slope population, Utah, was studied by Woodbury and Hardy (1948) and Hardy (1976), the population in the Pinto Basin, California, by Barrow (1979), and the population at Arden, Nevada, by Burge and Bradley (1976). Significance level: $*=p<0.05$.

\begin{tabular}{|c|c|c|c|c|c|c|c|c|}
\hline Study area & lot size $\left(\mathrm{km}^{2}\right)$ & Year(s) & Study type & $\begin{array}{l}\text { Total } \\
\text { counts }\end{array}$ & $\begin{array}{l}\text { Counts } \\
\text { of adults }\end{array}$ & $\begin{array}{l}\text { Counts } \\
\text { of adults } \\
\left(\text { per } \mathrm{km}^{2}\right)\end{array}$ & $\begin{array}{l}\text { Sex ratio } \\
\text { F:M }\end{array}$ & $\begin{array}{l}\% \text { adults: } \\
\text { non-adults }\end{array}$ \\
\hline Argus, CA & 13.70 & $1971-1972$ & Year-long & 47 & 35 & 2.6 & $25: 10^{*}$ & $76: 24$ \\
\hline Fremont Valley, CA & 2.59 & 1979 & Spring, 60d & 209 & 108 & 41.7 & $59: 49$ & $52: 48$ \\
\hline $\begin{array}{l}\text { Desert Tortoise Research } \\
\text { Natural Area (interior), CA }\end{array}$ & 2.85 & 1981 & Spring, 60d & 186 & 134 & 47.0 & $67: 67$ & $72: 28$ \\
\hline $\begin{array}{l}\text { Desert Tortoise Research } \\
\text { Natural Area (interp. center) }\end{array}$ & $\mathrm{r}), \mathrm{CA}^{7.80}$ & 1979 & Spring, 180d & 574 & 382 & 49.0 & $215: 167 *$ & $67: 33$ \\
\hline Fremont Peak, CA & 2.59 & 1980 & Spring, 60d & 43 & 27 & 10.4 & $11: 16$ & $63: 37$ \\
\hline Kramer, CA & 2.59 & 1980 & Spring, 60d & 146 & 84 & 32.4 & $42: 42$ & $58: 42$ \\
\hline Calico, CA & 2.59 & 1978 & Spring, 30d & 18 & 13 & 5.0 & $8: 5$ & $72: 28$ \\
\hline Stoddard Valley, CA & 2.59 & 1981 & Spring, 60d & 97 & 70 & 27.0 & $34: 36$ & $72: 28$ \\
\hline Lucerne Valley, CA & 2.59 & 1980 & Spring, 60d & 115 & 77 & 29.7 & $36: 41$ & $67: 33$ \\
\hline Johnson Valley, CA & 2.59 & 1980 & Spring, 60d & 65 & 40 & 15.4 & $20: 20$ & $62: 38$ \\
\hline Shadow Valley, CA & 3.89 & 1978 & Spring-,70d & 27 & 23 & 5.9 & $9: 14$ & $85: 15$ \\
\hline Ivanpah Valley, CA & 2.59 & 1979 & Spring, 60d & 155 & 87 & 30.1 & $41: 46$ & $56: 44$ \\
\hline Goffs, Fenner Valley, CA & 2.59 & 1979 & Spring, 60d & 296 & 186 & 62.8 & $74: 112 *$ & $63: 37$ \\
\hline Upper Ward Valley, CA & 2.59 & 1980 & Spring, 60d & 140 & 81 & 31.3 & $31: 50 *$ & $58: 42$ \\
\hline Pinto Basin, CA & 2.59 & 1978 & Spring \& fall, $19+4 d$ & 41 & 29 & 11.2 & $12: 17$ & $71: 29$ \\
\hline Chemehuevi Valley, CA & 4.66 & 1979 & Spring, $60 \mathrm{~d}$ & 149 & 100 & 21.5 & $43: 57$ & $67: 33$ \\
\hline Chuckwalla Bench, CA & 2.59 & 1979 & Spring, 60d & 265 & 166 & 64.1 & $81: 85$ & $63: 37$ \\
\hline Chuckwalla Valley II, CA & 2.59 & 1980 & Spring, 60d & 91 & 50 & 19.3 & $27: 23$ & $55: 45$ \\
\hline Arden, NV & 3.03 & $1974-1975$ & Multi-season & 127 & 90 & 29.7 & $57: 53$ & $71: 29$ \\
\hline Last Chance, NV & 3.89 & 1980 & Spring, 30d & 10 & 9 & 2.31 & $\mathrm{n} / \mathrm{d}$ & $90: 10$ \\
\hline Piute Valley, NV & 2.59 & 1979 & Spring, $60 \mathrm{~d}$ & 79 & 48 & 18.5 & $26: 22$ & $61: 39$ \\
\hline Sheep Mountain, NV & 2.59 & 1979 & Spring, 60d & 31 & 22 & 8.5 & 10:12 & $71: 29$ \\
\hline Beaver Dam Slope, UT & 4.86 & $1930-1946$ & Primarily fall-winter & 281 & $\mathrm{n} / \mathrm{d}$ & 23.9 & $151: 101 *$ & 99:01 \\
\hline
\end{tabular}




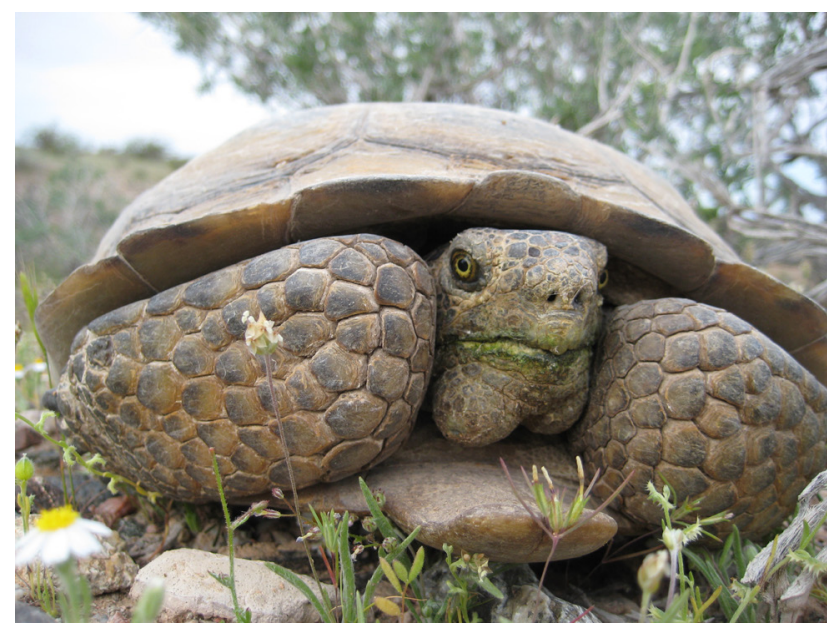

Figure 11.Adult male Gopherus agassizii with enlarged chin glands, a secondary sexual characteristic during the high testosterone season (August to October). Photo by Michael Tuma.

Physical changes in male chin glands occurred in association with the seasonal rise and fall of testosterone (Alberts et al.1994). Chin gland volume changed seasonally, reaching a maximum in late summer when testosterone levels were highest. In experimental studies, socially dominant individuals tended to have larger chin glands than subordinates. Both sexes were able to discriminate between chin gland secretions of familiar and unfamiliar males.

Population Structure. - Tortoises have been evaluated for size-class structure in populations using $\mathrm{CL}$ and grouped into seven size classes: juvenile $1,<60 \mathrm{~mm}$; juvenile 2, 60-99 mm; immature 1,100-139 mm; immature 2, 140-179 mm; subadult (small adult or young or both), 180-207 mm; adult 1, 208-239 mm; and adult 2, $\geq 240 \mathrm{~mm}$ (Berry 1984; Berry and Christopher 2001). Season, time of day, and method of searching have profoundly affected reported size-age class structure. For example, in the classic study by Woodbury and Hardy (1948), the authors focused search efforts on removing tortoises from dens in late fall and winter (November-February) in Utah. They marked 281 tortoises and published metrics for 117 . Of the 117 reported animals, $85(72.7 \%)$ were very large adults (adult 2 class), 25 (21.4\%) were in the adult 1 class, $6(5.1 \%)$ were subadults, and 1 $(0.85 \%)$ was an immature 2 . Thus, about $99 \%$ were adults and most were large. In contrast, searches and surveys of plots in California for all sizes of tortoises conducted in spring, between March and early June using two censuses, produced a higher proportion of populations in the juvenile and immature classes, especially when the surveyors focused on finding small tortoises (Berry and Turner 1986). Examples of study results where different survey techniques were used between the 1930s and early 1980s when tortoises were more common are presented in Table 2 (e.g., Berry 1984). With few exceptions, when two censuses were conducted in spring and efforts focused on finding juveniles, more juvenile and immature tortoises (28-48\%) were located.
McLuckie et al. (2002) reported finding 850 tortoises over a 4-year period at the Red Cliffs Desert Reserve, Utah, in a distance sampling effort focused on subadults and adults. The size-age structure was $7.1 \%$ juveniles, $10.4 \%$ immatures, and $82.59 \%$ subadults and adults. Keith et al. (2008) described a $187.7 \mathrm{~km}^{2}$ site (where tortoises were rare) and only four adults were observed in 760 one-ha, randomly located plots. Berry et al. (2008) described surveys of a 4 $\mathrm{km}^{2}$ site within a western Mojave State Park; 9 tortoises (4 immature, 1 subadult, and 4 adults) were observed. Lovich et al. (2011a) studied a population in the western Sonoran Desert with 69 marked tortoises of which $72.5 \%$ were adults. Berry et al. (2013) evaluated a $5.42 \mathrm{~km}^{2}$ site in the northwestern Mojave Desert and located 28 tortoises, of which $46.5 \%$ were adults and $53.6 \%$ were immature and juvenile tortoises. Berry et al. (2014a), in a study using randomly placed 1 ha plots in three management areas in the western Mojave Desert, located 17 tortoises; adults formed $76.5 \%$ of the sample.

Sex Ratios. - In studies conducted between the 1930s and early 1980s, sex ratios of adults in most populations were not significantly different than the expected $1: 1$ ratio (female:male; Table 2). Since the 1990s, sample sizes for adults in some studies were small and results varied by location. In the central Mojave Desert, Berry et al. (2006) reported that sex ratios differed significantly from the expected 1:1 ratio at 1 of 7 sites; the single site had a female to male ratio of 2:9. At two sites in the western Mojave Desert, few adults were observed; female to male sex ratios were 1:3 and 3:1 with one unidentified individual at each site (Berry et al. 2008; Keith et al. 2008). In the northwestern Mojave Desert, Berry et al. (2013) reported a 10:3 ratio, which differed significantly from the expected 1:1 ratio. In a western Mojave research project comparing three management areas, the sex ratio for the combined areas was 9:4, but did not differ significantly from the expected 1:1 ratio (Berry et al. 2014a). Berry et al. (2015a) evaluated 1,004 adult tortoises in an epidemiological study in the central Mojave Desert: the female to male sex ratio was 1:1.58. In the western Sonoran Desert, Lovich et al. (2011a) reported that a sex ratio of 51 marked tortoises did not differ from the expected 1:1 ratio.

Growth Rates. - Early studies on growth of wild adult tortoises revealed a range of rates. Woodbury and Hardy (1948) reported negligible growth in some adults over periods of $\leq 7$ years; however, one male grew from 206 to $302 \mathrm{~mm}$ in 4.3 years and one female grew from 204 to $239 \mathrm{~mm}$ in 7 years. Hardy (1976) re-visited the Woodbury and Hardy study area and described growth over periods of 17 to 26 years for four males and two females. Males grew $<0.5 \mathrm{~mm}$ per year and females grew $0.36 \mathrm{~mm}$ and $0.04 \mathrm{~mm}$ per year.

Medica et al. (2012) conducted a 47-year study under semi-wild conditions in 9 ha pens in the northern part of the 
geographic range. They tracked growth in 17 hatchling and juvenile tortoises to adulthood and death. Growth (plastron length) did not differ significantly between females (7.03 $\mathrm{mm} /$ year) and males $(7.49 \mathrm{~mm} /$ year) until the tortoises reached 23 to 25 years; after that female growth was limited and males continued to grow slowly. One small female was stunted and did not grow to sexual maturity. Growth rates were positively correlated with winter precipitation and growth of ephemeral vegetation. Growth rates were higher in years of high rainfall and were minimal when winter rainfall was $<26 \mathrm{~mm}$. Mack et al. (2018) reported a mean annual growth of $9.6 \mathrm{~mm} / \mathrm{year}$ in wild juvenile and immature tortoises at the Desert Tortoise Research Natural Area over multiple years.

Morbidityand Mortality. - Vulnerability to death varies by life stage, size, sex, and location or region. Predators and human activities are sources of injury or death. Droughts and diseases contribute directly and indirectly to deaths. We review the many causative factors below.

Drought, Dehydration, Starvation, and Temperature Extremes: - Tortoises of all sizes are vulnerable to death from dehydration and starvation during or shortly after droughts, and especially if droughts are prolonged (Peterson 1996; Berry et al. 2002; Longshore et al. 2003; Field et al. 2007; Lovich et al. 2014b; Nagy et al. 2015a). Necropsies of starving and dehydrated tortoises have revealed several potential bacterial pathogens,e.g., Bordetella bronchiseptica, Pasteurella testudinis, and Pseudomonas cepacia (Berry et al. 2002). Head-started juveniles released from pens and translocated adults have provided valuable information on sources of mortality: some juveniles released from headstart pens die of exposure, dehydration, and starvation, as do some translocated adults (Nussear et al. 2012; Nagy et al. 2015a,b).

Disease:-Infectious diseases described as contributing to illness and death in wild tortoises were upper respiratory tract diseases caused by Mycoplasma agassizii or $M$. testudineum or both (Brown et al. 1994, 1999; Christopher et al. 2003; Jacobson et al. 1991, 2014) and herpesviruses (Christopher et al. 2003; Jacobson et al. 2012). Johnson et al. (2006) reported high levels of exposure (86\%) to $M$. agassizii or herpesvirus or both in captive tortoises living in the western, central, and southern Mojave. Berry et al. (2015a) described consistently higher prevalence of testpositive tortoises close to human households in the central Mojave Desert for both M. agassizii and M. testudineum. The distribution of tortoises with $M$. agassizii and $M$. testudineum differed within the study area. Aiello et al. (2016) designed an experiment to model risk of transmission of M. agassizii. The models predicted low probability of infection when tortoise to tortoise interactions were brief, whereas tortoises with higher loads of the bacterium were predicted to transmit disease regardless of length of interaction. They observed encounters to be short in the wild and thus predicted more variability in responses. In another experimental study with captive tortoises, Aiello et al. (2018) discovered that tortoises were shedding bacteria regardless of the severity of clinical signs, although tortoises with severe clinical signs (nasal discharge) generally tended to shed more bacteria. Germano et al. (2014) conducted an experimental study to determine effects of M.agassizii on olfaction; the presence of a nasal discharge reduced smell and thus the ability to find food.

Bacterial and fungal pneumonia were reported in 3 of 24 necropsied wild tortoises (Homer et al. 1998). Dickinson et al. (2001) described higher levels of Pasteurella testudinis in ill tortoises, and Christopher et al. (2003) reported that $62 \%$ of all tortoises in a multi-year study at three Mojave Desert sites had moderate to heavy growth of P. testudinis.

Several non-infectious diseases were identified. Cutaneous dyskeratosis, a shell disease, was associated with illness, deaths, and population declines in the eastern Mojave and Colorado deserts (Jacobson et al. 1994; Homer et al.1998; Christopher et al.2003). Nutritional deficiencies or elemental toxicants may have caused this disease. Jacobson et al. (2009) described oxalosis, a disease of calcium oxalate crystals in the kidney and thyroid. Renal and articular gout occurred in a tortoise experiencing starvation and dehydration (Berry et al. 2002) and polyarticular and visceral gout was seen in a translocated tortoise (Jacobson and Berry 2012). Urolithiasis was documented in several tortoises in different areas of the desert (Jacobson 1994; Homer et al. 1998; Berry et al. 2002; and Christopher et al. 2003). Jacobson (1994) described osteopenia in bones of 24 tortoises from the Beaver Dam Slope, Utah, and northwestern Arizona; malnutrition was identified as responsible for the condition.

Elemental Toxicants and Toxicosis:-Elemental toxicants may affect health and contribute to responses to diseases (Jacobson et al. 1991; Jacobson et al. 1994; Selzer and Berry 2005; Chaffee and Berry 2006). Jacobson et al. (1991) reported that mercury concentrations in livers of tortoises with upper respiratory tract disease were significantly higher than in controls. Toxicosis was noted as a potential cause of cutaneous dyskeratosis (Jacobson et al. 1994). Selzer and Berry (2005), drawing on 4 necropsied tortoises from Homer et al. (1998), reported elevated levels of arsenic in ill tortoises but not in the control. Selzer and Berry (2005) detected arsenic in scutes using ICP-MS analyses and obtained results similar to Homer et al. (1998).

Parasites: - Ectoparasites include argasid ticks and an unidentified trombiculid mite (Woodbury and Hardy 1948; Jacobson 1994). Christopher et al. (2003) noted that ticks (Ornithodorus spp.) were significantly more likely to occur on tortoises in the year prior to observing oral lesions. Descriptions of internal parasites have included cysts of 

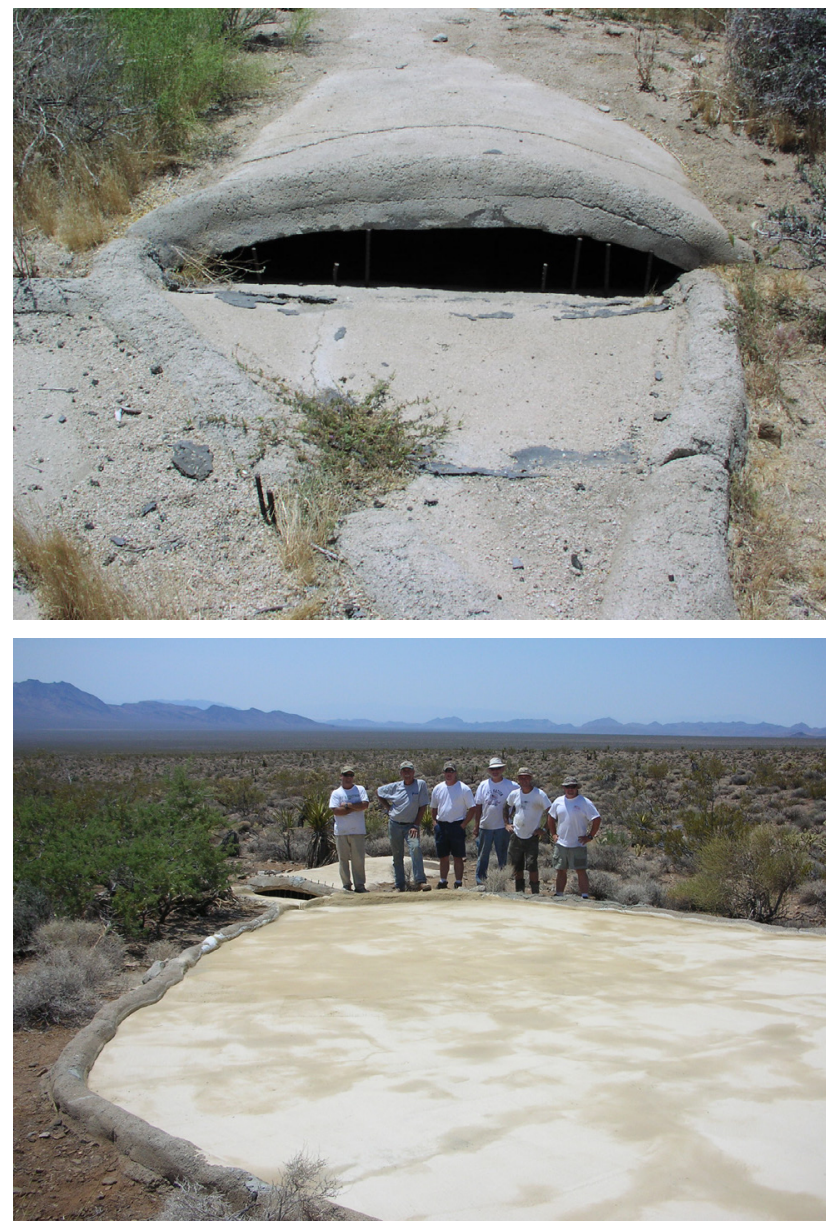

Figure 12. Rainwater catchment guzzler for wildlife at Mojave National Preserve, California; tortoises can become entrapped in guzzlers. Photos courtesy of Mojave National Preserve.

Sarcocystis-like protozoa in skeletal tissues, pinworms, and Balantidium-like protozoa in the colon(e.g., Jacobson 1994; Homer et al. 1998; Berry et al. 2002).

Entombment and Burrow Collapse: - Tortoise burrows may collapse due to human-related activities (domestic livestock grazing, vehicle use) or heavy winter precipitation. Nicholson and Humphreys (1981) observed sheep grazing on a Desert Tortoise study area in the western Mojave Desert; they reported damage and collapse of tortoise burrows and entrapment of a marked juvenile tortoise in its burrow (they dug out the burrow because the tortoise was unlikely to escape without assistance). Homer et al. (1998) reported the results of a necropsy of an adult female tortoise entombed in a burrow after winter rains; the tortoise had a cutaneous fungal infection and multicentric visceral inflammation resulting from the entombment. Loughran et al. (2011) described entrapment of four tortoises in burrows; one was encased in dried soil and died, but the others were able to escape. Tortoises can also become entrapped when burrows collapse from heavy rains and flooding (Homer et al. 1998; Christopher 1999; Field et al. 2007; Lovich et al. 2011b; Nussear et al. 2012).
Entrapment in Guzzlers and Cattle Guards: - Hoover (1995) examined 89 upland wildlife guzzlers (constructed rainwater catchments) in tortoise habitats in the western, northeastern, and eastern Mojave Desert and in the Colorado Desert. He found remains of 27 tortoises and one live tortoise in 18 guzzlers. Tortoises were trapped in the guzzlers and remains were found in all four desert regions. Later, Andrews et al. (2001) examined 13 tanks and guzzlers in the Colorado Desert, but did not find tortoise remains. Cattle guards are another source of entrapment for juvenile tortoises; they fall through the bars in the guards and are trapped below with no way to escape (Berry, pers. comm.).

Anthropogenic Trash:- Balloons, garbage, cans, paper, plastic bags, shooting targets, casings from shotgun shells, and ordnance are common in Desert Tortoise habitats (Berry et al. 2006, 2008, 2013, 2014a; Walde et al. 2007b; Keith et al. 2008). Some studies have shown a negative relationship between trash and tortoise sign (e.g., Keith et al. 2008). In one study, models revealed a positive association between tortoise sign and trash (Berry et al. 2014a), but this was an exception. Large objects (cars, refrigerators, detritus from construction sites) are also deposited in the desert. Tortoises can be attracted to and are known to consume balloons and other detritus that can negatively affect health and cause deaths (Donoghue 2006; Wyneken et al. 2006; Walde et al. 2007b). Trash, especially edible items, also has attracted subsidized predators of tortoises, such as the Common Raven (Corvus corax) and Coyotes (Canis latrans) and can have a negative influence (Boarman and Berry 1995; Cypher et al. 2018).

Livestock Grazing and Trampling: - Early discussions about effects of livestock grazing on tortoises focused primarily on competition for food, loss of food for the tortoises, trampling, and deterioration of habitat (Woodbury and Hardy 1948; Berry 1978). Berry (1978) described the evidence for probable trampling and death of a juvenile tortoise as well as potential conflicts in food availability and loss of shrub cover. Nicholson and Humphreys (1981) conducted a study of the effects of sheep grazing on a longterm, $2.59 \mathrm{~km}^{2}$ tortoise plot in the western Mojave Desert. Sheep used about $77 \%$ of the plot, $10 \%$ of 164 monitored burrows were damaged, $4 \%$ were destroyed, and one juvenile was trapped inside a trampled burrow. Nussear et al. (2012), in a study of both resident and translocated tortoises, noted that one tortoise died when livestock collapsed the burrow.

Predation:- Tortoise eggs are a food source for carnivorous vertebrates. Among reptiles, the Gila Monster consumes eggs (Beck 1990, Gienger and Tracy 2008) in the parts of the geographic range where the species overlap. Predatory mammals of tortoise eggs include Desert Kit Fox, Vulpes macrotis (Roberson et al. 1985; Turner et al. 1987; Bjurlin and Bissonette 2004; Sieg et al. 2015), Coyote (Roberson et al. 1985; Turner et al. 1987; Esque et al. 2010a; Berry et 


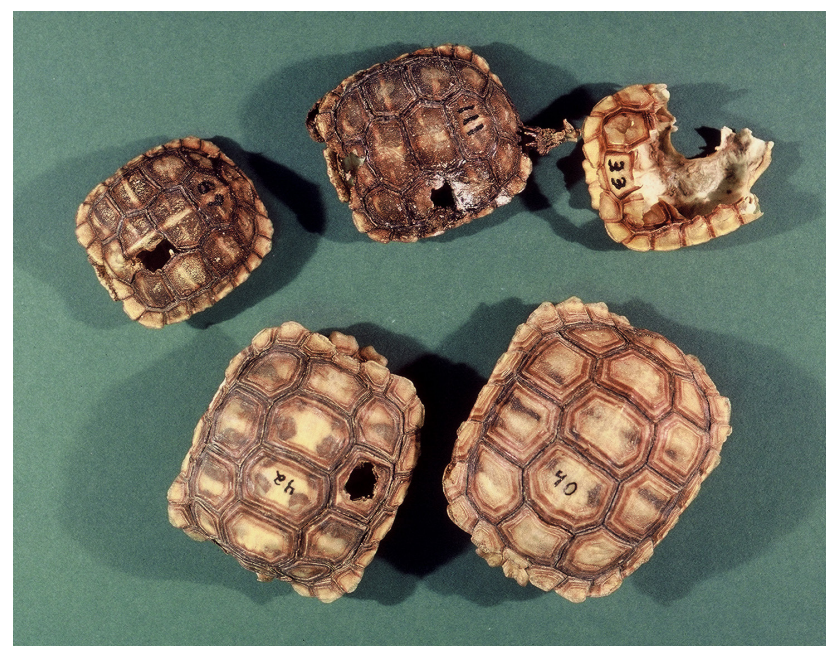

Figure 13. Juvenile Gopherus agassizii, killed by Common Ravens with typical peck holes in shells. Photo by Bev Steveson.

al. 2006; Lovich et al. 2014a; Sieg et al. 2015), American Badger,Taxidea taxus, and Spotted Skunks, Spilogale gracilis (Roberson et al. 1985; Sieg et al. 2015).

Neonates and juveniles may be attacked and killed by ants, including Fire Ants, Solenopsis spp.(Nagy et al.2015a; Mack et al.2018), Common Ravens (Campbell 1983; Farrell 1989; Lovich et al. 2011a; Berry et al. 2013; Hazard et al. 2015; Nagy et al. 2015a,b), Bobcats, Lynx rufus (Nagy et al. 2015b), Desert Kit Fox (Kelly et al. 2019), rodents (Nagy et al. 2015a,b), and Burrowing Owls (Walde et al. 2008). Common Ravens are very successful predators of juvenile and small immature tortoises and leave typical patterns on the remains of shells (Campbell 1983; Berry et al. 1986; Boarman and Berry 1995). Multiple kills of juveniles by Common Ravens have been described along fence lines, transmission lines, towers and poles, utility poles, and at perches and nests (e.g., Campbell 1983; $n=$ 136, along a multi-kilometer fence line; Farrell 1989, $n=$ 115, single nest). Kills have also been observed on open ground (Berry et al. 1986). Knight et al. (1998) reported finding remains of juveniles at cattle stock tanks. Parts of tortoises also were found in scats or pellets collected from the nests of Common Ravens (Camp et al. 1993).

Populations of Common Ravens have grown rapidly in the Mojave and western Sonoran deserts, supported by perennial food sources and water in urban and agricultural areas, small towns, and settlements (e.g., Knight et al. 1993; Boarman and Berry 1995; Boarman et al. 2006). The expansion of transportation and utility corridors, energy developments, livestock allotments, and recreational areas has supported growth of Common Raven populations, such that they are now considered subsidized predators - subsidized by anthropogenic activities (e.g., Kristan and Boarman 2003, 2007; Kristan et al. 2004; Webb et al. 2004, 2009; Boarman et al.2006). These developments have not only provided food and water to allow Ravens to survive and thrive, but also enabled their perching and nesting in hitherto inaccessible areas, thus penetrating into Desert Tortoise range areas previously inaccessible to Ravens.

Remains of juvenile tortoises also were observed in pellets of Red-tailed Hawks (Buteo jamaicensis) nesting on transmission line towers in the Colorado Desert (Anderson and Berry 2019). Red-tailed Hawks may be a subsidized predator, expanding perch and nest sites using transmission line towers throughout the range of the tortoise. Spenceley et al. (2015) described a failed attempt of a Glossy Snake (Arizona elegans) to kill a juvenile, head-started tortoise. Coyotes and Bobcats preyed on immature tortoises (Nagy et al. 2015b).

Carnivorous avian and mammalian predators have attacked and eaten wild and free-living adult tortoises. Common Ravens were observed to attack an adult tortoise (Woodman et al. 2013). Golden Eagles (Aquila chrysaetos) kill and eat adult tortoises; multiple broken shells were observed below eagle nests in the Mojave Desert (Berry, unpubl. data). Mammalian predators include Coyotes (Peterson 1994; Esque et al. 2010a; Lovich et al. 2014b), Bobcats and Mountain Lions (Puma concolor; Woodbury and Hardy 1948; Field et al. 2007; Medica and Greger 2009), American Badgers (Emblidge et al.2015), and domestic dogs (Canis lupus familiaris; Berry et al. 2014b). Both dogs and Coyotes were considered subsidized predators (Esque et al. 2010a; Cypher et al. 2018).

Collecting: - People have collected Desert Tortoises for food, commercial sale, and pets, and these activities have resulted in losses to wild populations, which we view as equivalent to deaths. Some Native American tribes, early settlers, and later residents engaged in collecting (e.g., Anonymous 1881; James 1906; Stephens 1914; Camp 1916; Jaeger 1922; Battye 1924; Grant 1936; Miller 1932, 1938; Woodbury and Hardy 1948; Schneider and Everson 1989).

In 1939, the California Fish and Game Commission published a regulation stating sale or purchase of any Desert Tortoise was unlawful (California Dept. of Fish and Game Code 1939-1981). By 1961, the regulation was amended to prohibit take, harm, and shooting. In 1972, regulations on possession and transport of tortoises were added, with the provision that persons able to demonstrate possession of a Desert Tortoise prior to publication of the 1972 regulations could retain the tortoise under certain conditions. Further constraints on possessing tortoises followed in 1989, culminating in the state and federal listings as a Threatened species (California Department of Fish and Wildlife 2016; USDI 1990). Other states did not have such stringent regulations as early.

In a collection of unpublished studies from the western Mojave Desert, Berry et al. (1996) summarized incidents of illegal take of tortoises using multiple data sources: law enforcement records, visual observations of poachers, signs 
of tortoise burrows dug up with shovels on transects and a long-term mark-recapture plot, demographic data from two long-term mark-recapture plots, and other information. The observations occurred between the mid-1980s and mid1990s; in retrospect, the observations appeared linked with the Asian Turtle Trade (see van Dijk et al. 2000). Several Cambodian nationals were arrested with 29 tortoises from a long-term plot, and several other Asians were observed in suspicious activities associated with collecting tortoises. Glenn Stewart (pers.obs.) reported the disappearance of $29 \%$ of radio-transmittered tortoises between 1986 and 1990 on his project; they were probably collected. Berry et al.(1996) estimated $>2000$ tortoises were removed from four study areas over a 10 -year period.

Illegal collecting has continued, e.g., from highways and roads, and some of these collected tortoises were transported to urban communities, parks, preserves, Natural Areas, and out of their native states. Grandmaison and Frary (2012) conducted a study on the probability of decoy Sonoran Desert Tortoises (G. morafkai) being detected and collected from paved roads, and maintained and non-maintained gravel roads; out of 561 opportunities for detection, motorists detected tortoises $19.3 \%$, and when detected, $7.4 \%$ of motorists attempted to collect the tortoise. Detection was greatest on maintained gravel roads. This finding points out the vulnerability of tortoises living within short distances of non-paved roads.

In a genetic study comparing captive tortoises from three desert communities in California and Nevada, only $44 \%$ of the captives were from the local communities and one was a G. morafkai (Edwards and Berry 2013). Studies of captive tortoises in desert communities in Arizona within the range of G. morafkai revealed that a high proportion of captives (25\%) were G. agassizii and an additional 14\% were hybrid G. agassizii x G. morafkai (Edwards et al. 2010). These findings indicated transport of G. agassizii into the geographic range of G. morafkai. In the last decade, wild G. agassizii, marked as part of research projects, have appeared in urban and ex-urban areas, obviously taken from the desert (Mark Massar, pers. obs.; California Turtle and Tortoise Club Adoption Program to Berry, pers. obs.).

Unauthorized Releases of Non-Native Tortoises: Examples of unauthorized releases into G. agassizii habitat include a Texas Tortoise (Gopherus berlandieri) and a Box Turtle at the Desert Tortoise Research Natural Area (Berry et al.1986). Several African Spurred Tortoises (Centrochelys sulcata), commonly sold as pets in the Southwest, were released illegally, discovered, and then removed from the Mojave and Sonoran deserts of California, Utah, and Arizona (e.g., Nelson 2010; Goolsby 2016; Anonymous 2018). This species can grow to a very large size $(68 \mathrm{~kg})$. Two African Spurred Tortoises were discovered and removed in October 2018 inside the Red Cliffs Desert Reserve, and officials at the

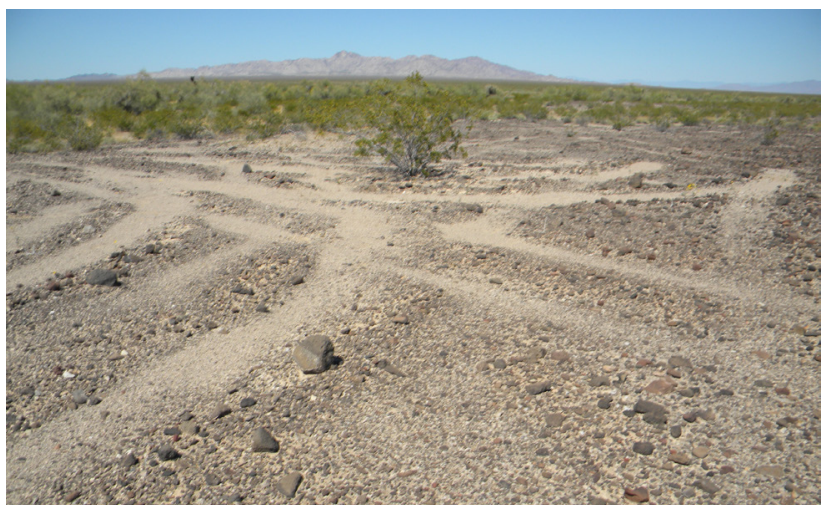

Figure 14. Residual impacts in 2009 of tank tracks and military training of troops in 1942 (67 years earlier) conducted by General Patton in Chemehuevi Valley, Colorado Desert, California. Photo courtesy of U.S. Geological Survey.

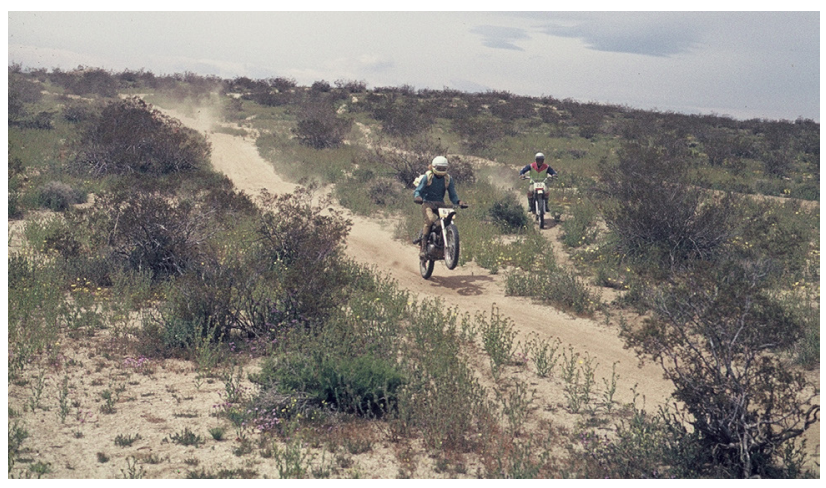

Figure 15. Unauthorized motorcycle race across the Desert Tortoise Research Natural Area, western Mojave Desert, California, creating new destructive trails. Photo by Kristin H. Berry.

Reserve expressed concern about the non-natives spreading disease and damaging habitat (Anonymous 2018).

The introduction of infectious and other diseases by turtles and tortoises from other parts of the United States and other countries has the potential for devastating effects on naïve G. agassizii. For example, in 2013, an ill Central Asian Tortoise (Testudo horsfieldii) was found and removed from the central Mojave Desert (Western Expansion Area of Fort Irwin), California. It was necropsied and tested positive for Mycoplasma agassizii using ELISA and also tested positive for a new herpesvirus using PCR, previously unreported in $G$. agassizii or T. horsfieldii (Jacobson et al. 2013; J. Wellehan, pers. obs.). The predominant bacteria in the nasal discharge was Mannheimia haemolytica, the cause of the epizootic pneumonia in cattle known as Shipping Fever (Jacobson et al. 2013).

Vandalism: - Numerous early reports documented vandalism, such as deliberately running over tortoises with vehicles, shooting, and maiming (Ragsdale 1939; Jaeger 1950; Bury and Marlow 1973; Uptain 1983). Berry (1986) evaluated 635 carcasses collected between 1976 and 1982 from 11 sites in the Mojave and western Sonoran deserts of California; 91 (14.3\%) remains showed evidence of gunshot. Gunshot deaths were more common in the western Mojave 
Desert (14.6-28.9\%) than in the eastern Mojave (0.0-3.1\%) and Colorado deserts (1.8-2.8\%). The higher levels of gunshot deaths in the western portion of the geographic range were attributed to much higher recreational use than in the east and south. Evidence of gunshot deaths was seen at Goldstone and within the southern edge of the Fort Irwin National Training Center (Berry et al. 2006). On the Alvord Slope, $8.5 \%$ of 47 shell remains showed evidence of gunshot. In the western Mojave Desert at Red Rock Canyon State Park, 5 of 58 shells showed evidence of gunshot (Berry et al. 2008). Also in the western Mojave Desert, evidence of tortoises killed by shooting occurred both in the Desert Research Natural Area and in adjacent designated critical habitat for the tortoise (Berry et al. 2014a).

Vehicular Impacts: - Records of tortoise injuries and kills by vehicles are frequent in the literature (e.g., Woodbury and Hardy 1948; Homer et al. 1998; von Seckendorff Hoff and Marlow 2002; Lovich et al. 2011a). Woodbury and Hardy (1948) considered the killing of tortoises on roads and removal by tourists and others as one of the dangers to the species. In a study of paved roads, von Seckendorff Hoff and Marlow (2002) found remains of 6 dead tortoises hit by vehicles on the shoulders of two- and four-lane roads in southern Nevada. Hughson and Darby (2013), in a study of $216 \mathrm{~km}$ of paved and two-lane roads in the Mojave National Preserve, estimated a minimum of 5.3 deaths of tortoises annually. Lovich et al. (2011a) found 11 dead tortoises over a 13-year period at a wind energy study site in the western Colorado Desert; one of the dead tortoises was killed by a vehicle.

Four studies have been undertaken to define the zone of influence of roads of different ages and traffic volumes on tortoises, with the assumption that roads serve as mortality sinks for adjacent tortoise populations. von Seckendorff Hoff and Marlow (2002) studied the effects of the road impact zone at intervals parallel to the roadways on roads with differing traffic volumes ( 25 to 5,000 vehicles per day) and

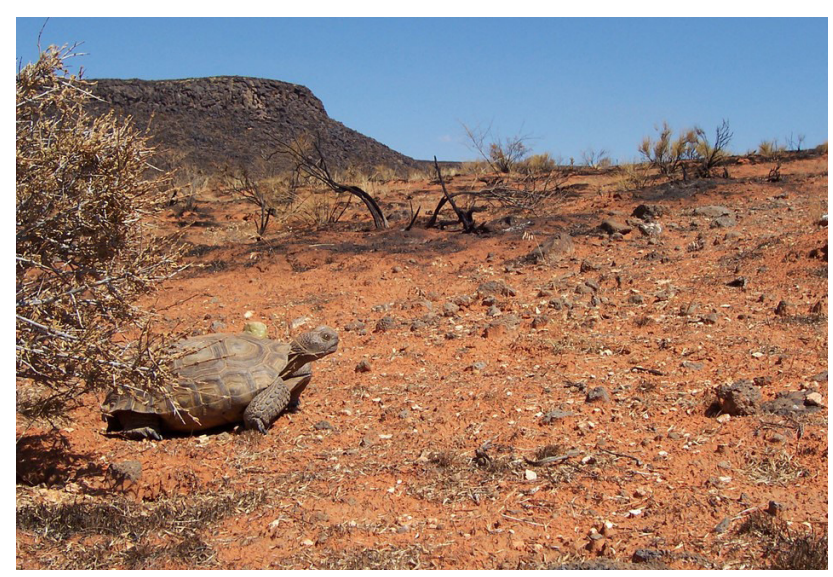

Figure 16. Adult Gopherus agassizii standing in burned habitat soon after the 2005 fire at the Red Cliffs Desert Reserve in Utah. Photo by Ann McLuckie. during different seasons. They found effects (reduction in abundance of tortoise sign) at distances of $>4,000 \mathrm{~m}$ from the road at the highest traffic level. However, the zone of impact ranged from 1,090 to $1,389 \mathrm{~m}$ for graded and maintained electric transmission line access roads.

Boarman and Sazaki (2006) conducted a more limited study along one major highway in the Mojave Desert with traffic of 8,500 vehicles per day. They found significant differences in sign counts between the highway edge and $400 \mathrm{~m}$ distant from the highway. Nafus et al. (2013) studied road effects in the Mojave National Preserve, California, and reported that tortoise sign was in greatest abundance along roads with low traffic volumes ( $<1$ vehicle/day) compared with roads of intermediate (30-60 vehicles/day) and high traffic volumes (320-1100 vehicles/day). Importantly, tortoise size negatively correlated with traffic volume. Highways and roads could affect the potential for population growth rates because reproductive tortoises were absent near the roads.

Hughson and Darby (2013), using the techniques of Boarman and Sazaki (2006), also saw similar depressions in tortoise sign near roads within the Mojave National Preserve. Agha et al. (2017) reported that mesocarnivore visits to tortoise burrows increased as distance to dirt roads decreased at a windfarm facility in the western Colorado Desert; however in an earlier study at the windfarm, tortoise burrows were more likely to occur closer to roads than at random points (Lovich and Daniels 2000).

Berry et al. (2006) studied Desert Tortoise populations on 21 plots on a military reservation; remains with signs of vehicle crushing were present on all plots with military maneuvers and represented from 2.1 to $45.5 \%$ of deaths on 20 of these plots. In a study in the northwestern Mojave Desert, Berry et al. (2013) modeled variables affecting distribution and abundance of tortoises on a military installation where no vehicle-related maneuvers occurred; the models included paved roads, denuded areas, ordnance, signs of mammalian

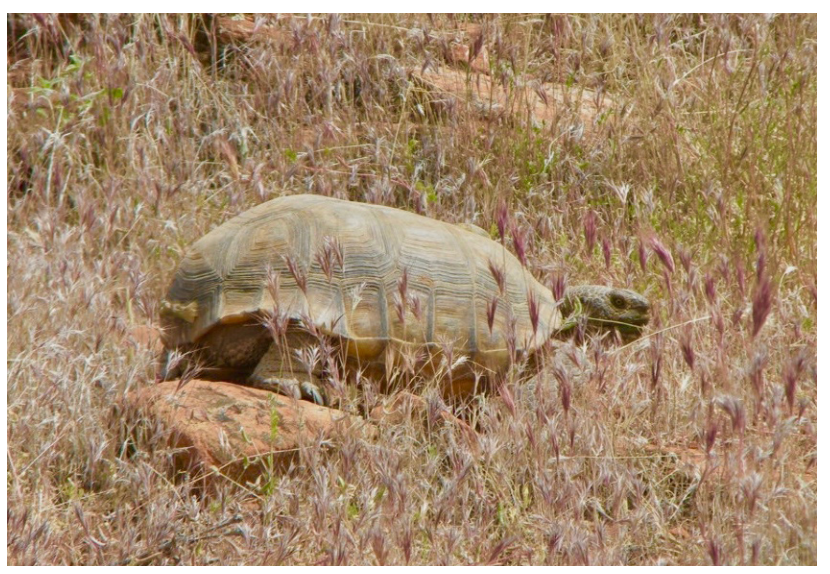

Figure 17. Impacts from fire and the resulting invasion of red brome grass (Bromus madritensis ssp. rubens) in the Red Cliffs Desert Reserve,Utah, two years post-fire (2007). Photo by Ann McLuckie. 
predators, and observations of Common Ravens. The models suggested that densities of tortoises increased with distances from paved roads and denuded areas, as well as some other variables.

Bury and Luckenbach (2002) found an immature tortoise crushed on a vehicle trail in a recreational vehicle use area. Remains of tortoises likely killed by unauthorized vehicle use were found in the Desert Tortoise Research Natural Area, an area closed to recreational vehicles (Berry et al. 2014a).

Fires: - Wildfires injure and kill tortoises (Woodbury and Hardy, 1948; Homer et al. 1998; Esque et al. 2003; Lovich et al. 2011c; Nussear et al. 2012; Ann McLuckie, pers. obs.). Woodbury and Hardy (1948) reported deaths of about 14 tortoises from a fire covering ca. $5.2 \mathrm{~km}^{2}$ on part of the Beaver Dam Slope south of Bunkerville in 1942. In a post-fire study, Lovich et al. (2011c) described a fire in the western Sonoran Desert that killed an adult female tortoise and injured five other adult tortoises. Nussear et al. (2012) reported that three of 30 tortoises died from fire during a comparative study of translocated and resident tortoises. In the Red Cliffs Desert Reserve and critical habitat in Utah, 687 tortoises died in 2005 in a fire that burned ca. $23 \%$ of the approximately $251 \mathrm{~km}^{2}$ habitat (A. McLuckie, pers. comm.). Drake et al. (2012) described a tortoise recovering from burns three years post-fire.

Two studies, one in the northeastern Mojave Desert and a second in the western Sonoran Desert, revealed that activity areas of tortoises remained unchanged in the first few years after a burn, indicating site fidelity, regardless of habitat condition (Lovich et al. 2018b). However, Drake et al. (2015) reported that six to seven years post-fire, tortoises contracted areas of activity because the post-fire growth of herbaceous perennial species (globemallow, Sphaeralcea ambigua) declined.

Mining: - Tortoises have been found alive and dead in mining shafts and pits, often in mining districts such as the Rand Mining District in the western Mojave Desert where pits and shafts are common (Berry, pers. obs.). Nussear et al. (2012) reported that two of 30 translocated and resident tortoises under study in the northeastern part of the geographic range were found dead in mineshafts.

Rattlesnake Bites: - An adult male tortoise, translocated 17 days previously as part of a mass translocation program, was attacked in the orbit and ultimately died from probable envenomation by a rattlesnake (Jacobson and Berry 2012; Berry et al. 2016a). Based on the appearance of the wound at necropsy, venom was most likely from the Speckled Rattlesnake, C.pyrrus, or Panamint Rattlesnake, C. stephensi. Rattlesnake bites or strikes as a cause of tortoise deaths are likely undercounted. Finding a tortoise dying of snake bite and obtaining a confirming necropsy would be unlikely, unless a tortoise was under observation or being tracked.
Mortality Rates. - Death rates are summarized following the reporting styles of the authors. Most studies focused on annualized death rates of subadult and adult tortoises (CL $\geq 180 \mathrm{~mm}$ ). In some cases, but not all, sites with little human use had lower mortality rates than sites with human-related activities. In their study of Desert Tortoises on the Beaver Dam Slope, Woodbury and Hardy (1948) reported a $1 \%$ annual death rate for a large sample of mostly adults. In a demographic study of tortoises on 21 study plots sampled between 1997 and 2003 in a military installation in the central Mojave Desert, adult ( $\geq 180 \mathrm{mmCL}$ ) death rates (adults dying / [yr km $\mathrm{km}^{-2}$ ) differed by location, and current and historical uses; death rates ranged from 1.9 to $95.2 \%$ annually (Berry et al. 2006). Fifteen plots within the Goldstone area had the highest death rate at $95.2 \%$. Sites with recent military vehicle use ranged from 4.7 to $13.3 \%$ and those with ongoing military vehicle-oriented war games ranged from 1.9 to $23.8 \%$. The single site surveyed adjacent to and outside of the military base had an annual death rate of $9.7 \%$ (Berry et al. 2006).

In the western Mojave Desert, Berry et al. (2008) studied a population within Red Rock Canyon State Park and reported a death rate of $67 \%$ for adults between 2000 and 2004 (ca. $24 \%$ annually); the death rate exceeded recruitment rates. In a survey of a $5.42 \mathrm{~km}^{2}$ plot on a naval test facility in the northwestern Mojave Desert, Berry et al. (2013) described a crude annual death rate of $1.8 \%$ for adults during the period 2006-2010. This site had limited public access with no livestock and no vehicle-oriented recreation. Berry et al. (2014a) compared demographic attributes of tortoises in three differently managed areas in the western Mojave Desert and provided crude annual death rates for adults for the 4 years preceding the survey. Death rates were lowest $(2.8 \% / y r)$ for the most protected area, the Desert Tortoise Research Natural Area, 20.4\%/yr in critical habitat, and $6.3 \% / y r$ on unfenced private lands with unrestricted human use (but recently acquired for conservation, 2000-2009).

Survival. - Few substantive studies have provided estimates of survival rates of Mojave Desert Tortoise populations. The most comprehensive of these was a study in the eastern Mojave Desert of California by Turner et al. (1987), covering the period 1977-1985. The study drew on 11 sex-size groups (CL in $\mathrm{mm}$ ), of which the first six were pre-reproductive: $<60,60-79,80-99,100-119,120-139$, 140-154, 155-179, females 180-208, males 180-208, females $>208$, and males $>208$. The authors, using markrecapture data, calculated annual survival rates for four periods between 1977 and 1985, as well as the geometric mean annual survival. The smallest three classes (juveniles) had geometric annual survival rates of 0.767 to 0.804 , and the immature tortoises (100-179 $\mathrm{mm} \mathrm{CL}$ ) had rates of 0.821 to 0.861 . Estimates for adult females were 0.901 to 0.944 and for adult males were 0.876 to 0.907 . All estimates had wide confidence intervals. Using this and other information, Turner 
et al. (1987) prepared a life table and estimated an annual rate of increase of the population of ca. 2\%. However, this population unfortunately crashed between 1994 and 2000, apparently due to disease and other factors (Christopher et al . 2003). Freilich et al. (2000), in a 1991-1995 mark-recapture study in Joshua Tree National Park, reported survival rate estimates of 0.84 or 0.901 , depending on method used, for both sexes of adult tortoises.

In the western edge of the Sonoran Desert, Agha et al. (2015c) compared apparent annual survival rates of adult tortoises over 18 years at two sites: inside a wind energy facility, a disturbed landscape, and nearby in an undisturbed landscape. Estimates of survival rates were $0.96 \pm 0.01$ for the wind energy facility, significantly higher than observed for the undisturbed site, $0.92 \pm 0.02$. High survival was attributed in part to limited human use.

In Nevada, Longshore et al. (2003) studied tortoises at two sites at Lake Meade National Recreation Area between 1994 and 2001. These authors reported annual survival rates of 0.985 at Grapevine and 0.829 at Cottonwood sites, where drought conditions existed from 1996 to 1999.

Population Status. - Historic and recent reports provide data for evaluating changes in status of tortoise populations. Before describing data, we briefly discuss sampling techniques because the methods used affect the types of results available.

Albeit limited, only observational reports on local abundance of tortoises exist from the early 1900s until the Woodbury and Hardy (1948) publication.For example, Grant (1936) described tortoises collected near Helendale in the western Mojave Desert.

Since the Woodbury and Hardy (1948) study until the early 2000s, mark-recapture studies on plots of various sizes have measured population attributes (structure, densities, sex ratios, growth, survival, causes of death), and some plots became long-term plots of about 2.6-7.8 $\mathrm{km}^{2}$ (Berry 1984). Selection of sites to study demography differed from one investigator to another and from state to state. In California, most sites represented habitat in valleys throughout the Mojave and Colorado deserts, whereas in Nevada, sites were chosen where belt transects indicated high counts of tortoise sign (Berry 1984). Mark-recapture surveys often spanned multiple years. Densities, one of several critical measures of population status and trends for the species, were frequently assessed through two or more mark-recapture surveys within a season. Data were analyzed using the Lincoln-Peterson index, stratified Lincoln index, Schnabel method, and other analytical techniques. In some cases, professional judgment was used to estimate densities. In addition, amounts of effort per unit area differed as well as season of survey. Changes in densities coupled with data on short-term trends in death rates or annualized mortality rates and survival for adults also provide supporting information and are presented above.
To summarize datasets on live tortoises from 1936 through the early 1980s briefly, we used the following counts: (1) all sizes of tortoises, and (2) all sizes of adults $(\geq 180 \mathrm{~mm}$ CL). These counts occurred within boundaries of plots (Table 2). Data are available for 24 sites with counts of $\geq 2$ tortoises $/ \mathrm{km}^{2}$; sites with lower densities were not included but are available in Berry (1984). Plot sizes ranged from 2.59 to $13.7 \mathrm{~km}^{2}$, with most plots $2.59 \mathrm{~km}^{2}$ and receiving two censuses or complete surveys in spring, when tortoises were likely to be above ground (Zimmerman et al. 1994). Counts of tortoises were converted to adults $/ \mathrm{km}^{2}$ for rough comparisons between sites and over time, and ranged from 2.31 to 71.8 adults $/ \mathrm{km}^{2}$ (Table 2). With few exceptions, most study plots listed in Table 2 are within critical habitat units designated by USFWS (1994).

From 1985 to 2006, counts and estimated densities of populations in many study areas declined markedly after the studies were initiated (e.g., Woodbury and Hardy 1948; Hardy 1976; Berry 1984; Jacobson et al. 1991, 1994; Berry and Medica 1995; Brown et al. 1999; Berry et al. 2002; Christopher et al. 2003). The population studied by Woodbury and Hardy (1948) on the Beaver Dam Slope was federally listed as Threatened in 1980 because of population declines and other factors (USFWS 1980). The listing of the entire metapopulation north and west of the Colorado River followed in 1990 (USDI 1990).

Examples of declines on mark-recapture plots include changes in adult tortoise populations in the Desert Tortoise Research Natural Area between 1982 and 1992, a decline of ca. $94 \%$ to about 6 tortoises $/ \mathrm{km}^{2}$ (Brown et al. 1999). The population (all sizes) in the western Sonoran Desert at Chuckwalla Bench also experienced a marked decline between 1979 and 1992. In contrast, adult densities remained relatively high during three surveys in Ivanpah Valley conducted between 1979 and 1994 (between 80 and 100/ $\mathrm{km}^{2}$ per survey) and during four surveys conducted at Goffs between 1980 and 1994 (between 145 and 190/km² per survey) (Berry and Medica 1995; Berry et al. 2002). The Goffs population experienced $92-96 \%$ decreases between 1994 and 2000 (Christopher et al. 2003). In Nevada, four populations with densities of adults $<50 / \mathrm{km}^{2}$ either remained stable, increased slightly, or decreased in the 1980s or between the 1980s and early 1990s (Berry and Medica 1995).

At least two mark-recapture plots listed in Table 2, Arden in Nevada and Fremont Peak in California, no longer have tortoises. Arden became urbanized shortly after the surveys were completed and is now part of Las Vegas (B.L. Burge, pers. obs), and Fremont Peak experienced sheep grazing and intensive vehicle-oriented recreation (Berry, pers. obs.).

Brief or one-time surveys of plots or study areas produced snapshots in time of both densities and mortality rates of breeding adults for the four years prior to each 
study (e.g., Berry et al. 2006, 2008, 2014a). While limited in time, these types of studies supplement long-term mark-recapture research and monitoring of changes in density conducted at a landscape scale. For example, one-time surveys undertaken at 15 plots on Goldstone and an additional six plots on the National Training Center at Fort Irwin revealed mean densities of adults of $0.79 / \mathrm{km}^{2}$ with a very high death rate of $95.2 \%$ annually for adults on the 15 Goldstone plots. In contrast, adult densities ranged from 1.4 to 15 adults $/ \mathrm{km}^{2}$ and death rates of adults from 1.9 to $23.8 \%$ annually on six Fort Irwin plots. In a health and disease research project spanning five years (1990-1995), annualized mortality rates for adult tortoises with radio transmitters were available for three sites: the western (2.5\%), northeastern (2.4\%), and eastern $(5.1 \%)$ Mojave Desert regions (Christopher et al. 2003). Tortoises missing (some were potentially dead) at each site ranged from $22.9 \%$ (eastern Mojave) to $37.5 \%$ (western Mojave) over the 5-year study. One-time studies using hectare plots or study areas also indicated high mortality rates in some areas (Berry et al. 2006, 2008; Keith et al. 2008). Small, remnant and potentially isolated populations remained in the north central and northwestern Mojave in the early 2000s (Berry et al. 2006, 2008, 2013; Keith et al. 2008). Death rates of adults tracked with radio-transmitters were high in some studies (Longshore et al. 2003; Christopher et al. 2003), but not in others (Agha et al. 2015c).
Surveys at the Landscape Scale. - The first G. agassizii Recovery Plan published in 1994 recommended sampling on a landscape scale within designated areas designed for conservation of the Desert Tortoise, i.e., Desert Wildlife Management Areas, in addition to maintaining long-term plots, where appropriate (USFWS 1994a). After testing different approaches, in 2004 the USFWS implemented annual distance sampling of adults ( $\geq 180 \mathrm{~mm} \mathrm{CL}$ ) within designated critical habitat units (now called Tortoise Conservation Areas, TCAs) throughout the geographic range (McLuckie et al. 2002; USFWS 2015; Allison and McLuckie 2018). The primary population attribute published from distance sampling was density of adults within critical habitat units or TCAs (Table 3). The first Recovery Plan also recommended separating populations into six Recovery Units, each of which contained one or more populations (e.g., critical habitat units), with a total of $>25,000 \mathrm{~km}^{2}$ (USFWS 1994). In the revised Recovery Plan, the USFWS (2011) reduced the number of Recovery Units to five and realigned boundaries based solely on genetic information in Hagerty and Tracy (2010).

Range-wide, the five Recovery Units contain 17 TCAs scattered in the Mojave and western Sonoran deserts of the four states (Table 3). Grouped data for all TCAs showed a decline of $32.18 \%$ in adult tortoises between 2004 and 2014 , with declines of 26.57 to $64.70 \%$ for 11 individual TCAs (USFWS 2015). Six TCAs showed increases of 162.36

Table 3. Summary of 10-year trend data for five Recovery Units and 17 Tortoise Conservation Areas within the Recovery Units for the Mojave Desert Tortoise, Gopherus agassizii, between 2004 and 2014 (modified from Table 10 in USFWS 2015). This table includes the area of each Recovery Unit and Tortoise Conservation Area (= critical habitat), the percent of total habitat in each of the five Recovery Units and 17 Tortoise Conservation Areas, density (number of breeding adults $/ \mathrm{km}^{2}$ and standard errors, SE), and the percent 10 -year change between 2004-2014. Note: according to Table 2 in the revised recovery plan (USFWS 2011), the total critical habitat is 26,039 $\mathrm{km}^{2}$, whereas the text states $24,281 \mathrm{~km}^{2}$. Numbers in bold represent the totals for each Recovery Unit. * = Populations falling below the viable level of 3.9 breeding individuals $/ \mathrm{km}^{2}$. ${ }^{1}$ Chocolate Mountains Aerial Gunnery Range.

\begin{tabular}{|c|c|c|c|c|}
\hline $\begin{array}{l}\text { Recovery Unit } \\
\text { Tortoise Conservation Area }\end{array}$ & $\begin{array}{l}\text { Surveyed area } \\
\qquad\left(\mathrm{km}^{2}\right)\end{array}$ & $\begin{array}{c}\% \text { of total } \\
\text { habitat in } \\
\text { Recovery } \\
\text { Unit \& TCA }\end{array}$ & $\begin{array}{c}2014 \\
\text { density } / \mathrm{km}^{2} \\
(\mathrm{SE})\end{array}$ & $\begin{array}{c}\% \text { 10-year } \\
\text { change } \\
(2004-2014)\end{array}$ \\
\hline Western Mojave, CA & 6,294 & 24.51 & $* 2.8(1.0)$ & -50.7 decline \\
\hline Fremont-Kramer, CA & 2,347 & 9.14 & $* 2.6(1.0)$ & -50.6 \\
\hline Ord-Rodman, CA & 852 & 3.32 & $* 3.6(1.4)$ & -56.5 \\
\hline Superior-Cronese, CA & 3,094 & 12.05 & $* 2.4(0.9)$ & -61.5 \\
\hline Colorado Desert $\left(1^{\circ} \mathrm{CA}\right)$ & 11,663 & 45.42 & $4.0(1.4)$ & -36.3 decline \\
\hline Chocolate MAGR ${ }^{1}, \mathrm{CA}$ & 713 & 2.78 & $7.2(2.8)$ & -29.8 \\
\hline Chuckwalla, CA & 2,818 & 10.97 & $* 3.3(1.3)$ & -37.4 \\
\hline Chemehuevi, CA & 3,763 & 14.65 & $* 2.8(1.1)$ & -64.7 \\
\hline Fenner, CA & 1,782 & 6.94 & $4.8(1.9)$ & -52.9 \\
\hline Joshua Tree, CA & 1,152 & 4.49 & *3.7 (1.5) & +178.6 \\
\hline Pinto Mountain, CA & 508 & 1.98 & $* 2.4(1.0)$ & -60.3 \\
\hline Piute Valley, NV & 927 & 3.61 & $5.3(2.1)$ & +162.4 \\
\hline Northeastern Mojave, NV, UT, AZ & 4,160 & 16.2 & $4.5(1.9)$ & +325.6 increase \\
\hline Beaver Dam S., NV, UT, AZ & 750 & 2.92 & $6.2(2.4)$ & +370.3 \\
\hline Coyote Spring, NV & 960 & 3.74 & $4.0(1.6)$ & +265.1 \\
\hline Gold Butte, NV \& AZ & 1,607 & 6.26 & $* 2.7(1.0)$ & +384.4 \\
\hline Mormon Mesa, NV & 844 & 3.29 & $6.4(2.5)$ & +217.8 \\
\hline Eastern Mojave, NV \& CA & 3,446 & 13.42 & $* 1.9(0.7)$ & -67.3 decline \\
\hline El Dorado Valley, NV & 999 & 3.89 & $* 1.5(0.6)$ & -61.1 \\
\hline Ivanpah Valley, CA & 2,447 & 9.53 & $* 2.3(0.9)$ & -56.1 \\
\hline Upper Virgin River, UT & 115 & 0.45 & $15.3(6.0)$ & -26.6 decline \\
\hline Red Cliffs Desert Reserve, UT & 115 & 0.45 & $15.3(6.0)$ & -26.6 \\
\hline Total Amount of Land & 25,678 & 100.00 & & -32.2 decline \\
\hline
\end{tabular}


to $384.37 \%$. Ten TCAs were below a density of 3.9 adult tortoises $/ \mathrm{km}^{2}$, a figure established for population viability described in the first Recovery Plan (USFWS 1994). No data are available on the sex ratios of females to males in the 17 TCAs.

Most TCAs (10 of 17, 75.9\%) occur in California. Nine of these 10 populations declined by 29.77 to $64.70 \%$ between 2004 and 2014, and eight were below the numeric level of viability (not considering the Standard Error, Table 3). The two populations that were above viability also declined, and one population, Joshua Tree, showed an increase (USFWS 2015).

Nevada, with $17.9 \%$ of TCAs, has parts or all of six populations and five of these show increases; two of the six were below viability. About $4 \%$ of TCAs (parts of two populations) occur in Arizona and are shared with Nevada and Utah. Both TCAs were increasing but one was below viability. Utah has $<2 \%$ of populations in TCAs: the Beaver Dam Slope which is showing an increase, and the Red Cliffs Desert Reserve which is declining. In addition, observations of juveniles have decreased (Allison and McLuckie 2018). Reviewing all these results, Allison and McLuckie (2018) concluded that "The negative population trends in most of the TCAs [critical habitat units] for Mojave Desert Tortoises indicate that this species is on the path to extinction under current conditions."

Populations in protected or partially protected areas (State Parks, National Park system, Research Natural Areas, Reserves, Areas of Critical Environmental Concern) experienced downward trends and/or high mortality rates with few exceptions (Berry and Medica 1995; Longshore et al. 2003; Berry et al. 2008; Lovich et al. 2014b; USFWS 2015 [Red Cliffs Desert Reserve]). A one-season study undertaken in the western Mojave in 2011 compared effects of different management practices on population status in a fenced and protected area (Desert Tortoise Research Natural Area), adjacent unfenced private land, and critical habitat (Berry et al. 2014a). Significantly higher density of tortoises occurred in the protected area (10.2 adults $/ \mathrm{km}^{2}, 95 \%$ Confidence Interval [CI]: 9.9-10.4) compared with adjacent private land (3.7 adults $/ \mathrm{km}^{2}$; 95\% CI: 3.6-3.8) and critical habitat (2.4 adults $/ \mathrm{km}^{2}, 95 \%$ CI: $\left.2.3-2.6\right)$. Death rates of adults from 2007 to 2011 were also lower in the protected area $(2.8 \% / \mathrm{yr})$ than on private land $(6.3 \% / \mathrm{yr})$ or in critical habitat (20.4\%/yr).

Threats to Survival. - The decline of G. agassizii is often described by scientists as death by a thousand cuts. Population declines can be ascribed simply to the rate of loss of individuals greater than the rate of recruitment and the rate of loss or degradation of habitat. Causes of declines vary locally and regionally within the geographic range and by critical habitat unit or TCA (e.g., Jacobson et al. 1991; Berry et al. 2014a; Tuma et al. 2016). Overall, the causes are multiple, cumulative, and often synergistic, but the most important drivers are anthropogenic activities. The same and similar anthropogenic drivers are the basis for environmental change and degradation elsewhere in the American West (Leu et al. 2008).

In the section on Morbidity and Mortality above, we described multiple sources of illness, death, and loss of individual tortoises to populations. High on this list of threats are disease, poor nutrition, starvation and dehydration, predation by subsidized predators (e.g., Common Raven, Coyote, dog), loss to vehicle impacts, and destructive wildfires. The importance of other hazards and causes of mortality should not be discounted or minimized, especially because tortoise population densities are so low, bordering or below viability for breeding adults (Table 3; viability summarized in USFWS 1994). With continuing growth of human populations and industrial developments within and on the edges of the geographic range for G. agassizii (e.g., Hughson 2009), we expect that deaths from known and additional sources will continue and likely increase.

Habitat Loss and Fragmentation. - Constrictions to and fragmentation of the geographic range of the Desert Tortoise began when early settlers arrived in the 1800 s. Settlements grew into towns and cities and land was converted to agriculture, ranching, and scattered mining operations. Transportation and utility corridors developed, and recreational focal points became popular.

As of 2018, the southwestern part of the geographic range in Antelope, Victor,Apple, and parts of Brisbane and Peerless valleys were in urban, ex-urban, industrial, and agricultural developments. The western edge of the range was similarly compromised. Habitat across the southern, central, eastern, and northeastern regions of the Mojave and Colorado deserts experienced similar losses and fragmentation of habitat until and after the time of the federal listing in 1990 (e.g., Norris 1982; Hughson 2009; USFWS 2010). Subsequently, the area of tortoise habitat (including critical habitat) has continued to decrease, with development of private and federal lands for urban, ex-urban, agricultural, industrial, and energy developments, and expansion of Department of Defense military bases in the central, southern, and northeastern Mojave Desert and elsewhere (e.g., USFWS 2010). For example, between 1992 and 2001,4.57 km² of critical habitat was lost from agricultural development, a small amount compared to the past, but nevertheless a continuing issue. Range-wide, 1,802 $\mathrm{km}^{2}$ of critical habitat occurred on U.S. Department of Defense lands (USFWS 2010). Due to the expansion of the National Training Center at Fort Irwin in the central Mojave Desert, $760 \mathrm{~km}^{2}$ of tortoise habitat was lost or degraded; ca. $304 \mathrm{~km}^{2}$ of this loss was part of critical habitat (USFWS 2010). The expansion of the Marine Corps Air Ground Combat Center at Twentynine Palms in the southern Mojave Desert has had and is likely to have 
continued and profound effects on tortoise populations within and outside critical habitat units (USDD 2017; Henen 2018). Since 2000, development of renewable energy has resulted in loss of about $25 \mathrm{~km}^{2}$ of high value tortoise habitat (but not critical habitat) in the northeastern Mojave Desert and ca. $81 \mathrm{~km}^{2}$ of marginal habitat in the Colorado Desert (Mark Massar, U.S. Bureau of Land Management, in litt. 25 Oct 2018).

Transportation, energy and utility corridors, and railroads connect cities, towns, settlements, and developments across and within the geographic range of the tortoise, resulting in lost and degraded habitat, fragmentation of habitat, and loss of connectivity (Forman et al.2003; Chaffee and Berry 2006). The USFWS (2010) reported a total length of 13,350 $\mathrm{km}$ of paved roads and highways in critical habitat in 1990, with a slight difference in 2008 . If the $13,350 \mathrm{~km}$ are treated solely as two-lane highways with shoulders (width, $11.6 \mathrm{~m}$ ), then total loss is $1,548 \mathrm{~km}^{2}$. This figure does not include 4- and 6-lane or divided highways. The revised Recovery Plan showed substantially fewer kilometers of roads where fencing is needed, but does not resolve discrepancies with the 2010 report (USFWS 2010, 2011). The USFWS (2010) also noted $1,634 \mathrm{~km}$ of utility lines within corridors encompassing $1,743 \mathrm{~km}^{2}$ (width of utility corridors $=1.067 \mathrm{~km}$ ). Utility corridors have one or more access roads, often dirt with berms, and the roads have increased in length and area with development of renewable energy facilities on public and private lands. Data on other linear disturbances are available for TCAs, e.g., for railroads, $368 \mathrm{~km}$ (USFWS 2011).

In addition to acting as a mortality sink for tortoises, roads, whether dirt or paved, and railroads are sources of contaminants such as asbestos, cadmium, chromium, lead, nickel, petroleum products, and organic compounds (Forman et al. 2003; Chaffee and Berry 2006).

Solar and wind energy developments are present in Desert Tortoise habitat (habitat modeled by Nussear et al.2009). For example, as of 2010, solar development was implemented on $114 \mathrm{~km}^{2}$ of all modelled habitat, with additional solar and wind projects pending for $230 \mathrm{~km}^{2}$ (USFWS 2011). As of 2018, more solar and wind sites are proposed or in development, generally not in critical habitat, but occasionally close to or adjacent to critical habitat or protected areas.

The U.S. Bureau of Land Management has received pressure from users of off-highway vehicles since the early 1970 s to provide easy access to the desert, and places for unrestricted play (e.g., USBLM 1973, 1980, 2019). Several off-highway vehicle "Open Areas" where unrestricted vehicle use occurs were designated in California in 1980 and reaffirmed with the Desert Renewable Energy Conservation Plan in California, resulting in the gradual loss of ca. 898 $\mathrm{km}^{2}$ of good, if not prime, tortoise habitat (USBLM 1980, 2016; Mark Massar, U.S. Bureau of Land Management, in litt. 6 Nov 2018).
The pressure for vehicle-oriented recreation off-highways and off-roads came from thousands of users and continues to have a growing influence on degrading tortoise habitat through thousands of routes, trails, congregating areas for races (called pit areas), and the proliferation of unauthorized, cross-country use (e.g., Bury and Luckenbach 2002; Berry et al. 2014a). Numerous research articles on effects of vehicle travel off-road on soils and vegetation in the Mojave Desert have been published documenting severe damage to the environment (e.g., Adams et al. 1982; Webb and Wilshire 1983; Wilshire and Nakata 1976; Lei 2009; Brooks and Lair 2009). Although several management plans designed to limit off-highway or off-road use were published, proliferation of these uses into unauthorized areas has continued on both federal and private lands (USBLM 1973, 1980, 2016, 2019). In parts of critical habitat in the western, central, and southern Mojave Desert, visits and visitor days recorded annually from 2008 to 2018 ranged from 55,874 to 94,474 visits and from 26,218 to 90,445 visitor days per year (USBLM 2019, Table 3.6-4). Off-highway and off-road use has also grown in the Colorado Desert in the Chuckwalla Bench critical habitat, where some vehicle users have pushed down signs indicating "closed to vehicle use" and driven into sensitive areas, such as washes (Berry, pers. obs., 2018).

As of 2017, existing routes and trails developed by offhighway vehicle users covered an estimated $3,765 \mathrm{~km}$ in critical habitat in the Western Mojave Recovery Unit alone, with an additional $148 \mathrm{~km}^{2}$ negatively affected by stopping, parking, and camping adjacent to the trails and routes (USBLM 2019). These figures do not include unauthorized tracks, trails, and routes, which are common in the region (Goodlett and Goodlett 1992; Keith et al. 2008; Egan et al. 2012; Berry et al. 2014a; Piechowski 2015).

The high density of off-road routes and trails, both authorized and unauthorized, in critical habitat and other sensitive areas for rare, threatened, and endangered species in this region continues to be of concern to nonprofit organizations and government agencies and is the subject of court cases (USDC 2009, 2011). The final management plan developed by the U.S. Bureau of Land Management for federal lands (USBLM 2019) indicates only 3,314 km of open and limited routes for off-highway vehicle (OHV) use, and $98 \mathrm{~km}^{2}$ for camping, parking, and stopping adjacent to routes within critical habitat. When all disturbances from transportation linear features (all linear features on the ground) are considered, the figure is $4,173 \mathrm{~km}$ (USBLM 2019, Alternative 5). Therefore, density of existing linear disturbances from OHV routes and other linear transportation features in critical habitat in the Western Mojave Recovery Unit is $1.05 \mathrm{~km} / \mathrm{km}^{2}$ (4173 $\mathrm{km} / 3963 \mathrm{~km}^{2}$ of critical habitat). These figures do not include individual tracks or areas degraded from parking, camping, and stopping of OHVs, mining, piospheres created 
by livestock grazing, and other land uses. Although figures are not available for other Recovery Units, the Colorado Recovery Unit faces increasing and new pressures from unauthorized cross-country vehicular travel.

Subsidized Predators. - Direct links exist between subsidies for Common Ravens, Coyotes, and dogs (e.g., road kills, trash, and domestic pets) and desert cities, towns, and settlements. This also involves transportation corridors (roads, railroads, utility corridors), renewable energy facilities, and recreation vehicle use areas (Boarman 1993; Knight and Kawashima 1993; Knight et al. 1993, 1999; Fedriani et al. 2001; Kristan et al. 2004; Esque et al. 2010a; Cypher et al. 2018). Utility poles and transmission line towers serve as perches for foraging and nest sites for Common Ravens, allowing access to previously uninhabited or rarely used and remote parts of the desert.

In surveys conducted in the eastern Mojave Desert, the Common Raven was the most commonly observed bird (Knight et al. 1999); it also was the most common species observed over seven survey years at the Desert Tortoise Research Natural Area in the western Mojave Desert between 1979 and 2012 (Berry et al., in review). Ravens form small and large flocks (250 to 5,900 individuals) at roosts in trees and along utility lines in or near desert towns and ex-urban areas in the western, southern, and eastern Mojave Desert (Tim Shields, pers. obs. 2011 to 2018; Debra Hughson, pers. obs.). One such roost covered an area of $0.8 \times 0.8 \mathrm{~km}$ and regularly had from 1,000 to 5,900 ravens. Shields (pers. obs.) reported that counts peak in late fall and winter. Kristan and Boarman (2003) in a study of raven predation on tortoises in the western Mojave Desert described patterns of spillover predation and hyperpredation and stated that "anthropogenic resources for ravens could indirectly lead to the suppression, decline, or even extinction of desert tortoise populations." Ravens also were observed to attack adult tortoises (Woodman et al. 2013).

Another subsidized predator, the Coyote, kills and eats tortoises. In a study of nine sites in the Mojave Desert, Esque et al. (2010a) reported that high mortality of adult tortoises correlated with sizes of nearby human populations, surface roughness of the landscape, and size and sex of the tortoise. Potential contributing factors were distance of the human population and density of roads. Tortoises were more likely to be killed during and after droughts, when populations of typical prey-hares and rodents-were low. Mortality rates at the nine sites ranged from 0 to $43.5 \%$; two sites experienced no deaths. In a 5-year study of Coyote diets in the central Mojave Desert, Cypher et al. (2018) reported that in years of low precipitation, the diet of Coyotes included more anthropogenic food items. They also observed higher frequencies of tortoise remains in Coyote scats in the two years following releases of translocated tortoises.
Domestic dogs, also subsidized predators, attack, injure, and kill captive tortoises and were observed to attack wild tortoises (Boyer and Boyer 2006; Berry et al. 2014a; Berry, pers. obs.). Dogs occur singly and in large packs (e.g., 12-35 dogs) and have been observed in the western, central, and southern Mojave Desert (Berry, Rhys Evans, Michael Tuma, Mark Bratton,pers.obs.). Without exception, dog packs were close to military installations and associated with urban or ex-urban settlements. In all observations, dogs threatened the field workers.

Habitat Degradation. - Many sources of habitat degradation exist, such as military maneuvers, livestock grazing, and mining. Military maneuvers (tanks, other vehicles, troops) have negative effects on tortoise habitat. During World War II, between 1942 and 1944, General Patton trained an estimated one million troops for North Africa on $50,000 \mathrm{~km}^{2}$ in southeastern California, southern Nevada, and western Arizona, using thousands of tanks and other vehicles (Prose 1986; Prose and Wilshire 2000). In 1964, Operation Desert Strike trained in much of the same area and covered $2,000 \mathrm{~km}^{2}$. The affected habitats extend from the central Mojave Desert in the Western Mojave Recovery Unit east into the Eastern Mojave Recovery Unit, and south to the entire Colorado Desert Recovery Unit.

Depending on site and year of impact, tank tracks from military vehicles and camps caused substantial and often significant and negative effects on soils and plants (Prose 1985, 1986; Prose et al. 1987, Prose and Wilshire 2000). Examples include, but are not limited to, compaction of soils in tank tracks, lowered infiltration rates of soil, removal of the top layer of soil, and alteration of densities of drainage channels. Recovery of cryptobiotic crusts was lower in tank tracks (Prose and Wilshire 2000). Cover and density of creosote bushes were greatly reduced where significant alterations occurred in the substrate; pioneer species of shrubs dominated in most disturbed areas (Prose et al . 1987). Cover of some annual forbs consumed by tortoises, e.g., desert dandelion (Malacothrix glabrata) and Fremont's pincushion (Chaenactis fremontii) was lower in tank tracks (Prose and Wilshire 2000). However, annual forbs were often in higher densities in tank tracks than in control areas, but plants were smaller in size. Grasses also were in greater densities in tank tracks. As of 2018, the scars of the tracked vehicles from the 1942 maneuvers remained evident on desert pavement (Berry, pers. obs.).

Grazing by cattle, sheep, horses, and feral burros began in the mid-1800s in the Mojave and Colorado deserts and is responsible for habitat degradation in many areas (e.g., Spears 1892; Wentworth 1948; Webb and Stielstra 1978; Johnston 1987; Stone 1989; Fleischner 1994; Abella 2008). The USFWS (2010) reported that ca. $12,881.5 \mathrm{~km}^{2}$ or approximately $50 \%$ of critical habitat was grazed at the time of the federal listing in 1990 ; subsequently $8,479.9 \mathrm{~km}^{2}$ 
of the allotments and leases involved were closed, leaving $4,401.7 \mathrm{~km}^{2}(17.1 \%)$ of critical habitat still with allotments and leases. Recently, some allotments were renewed for 10 years in the West Mojave Recovery Unit.

Fleischner (1994) described three broad categories of negative effects of grazing to habitat, including alteration of species composition in vegetation associations, disruption of ecosystem functioning, and changes to ecosystem structure. Reduction in biomass and diversity of native annual and herbaceous perennial species has remained a critical issue for the Desert Tortoise, a selective forager, as has competition for forage (e.g., Avery and Neibergs 1997; Oftedal 2002; Oftedal et al. 2002; Jennings and Berry 2015).

The U.S. Bureau of Land Management, responsible for issuing leases and managing allotments and licenses on public land, recognized the negative effects of sheep when establishing the Desert Tortoise Research Natural Area between 1972 and 1980 (Webb and Steilstra 1979; Berry et al. 2014a), and sheep were therefore excluded within the boundaries. In 1990, the year the Desert Tortoise was listed as a Threatened species, sheep grazing was removed from areas expected to become critical habitat. Tuma et al. (2016), in a model of anthropogenic impacts to two study sites within the geographic range, listed grazing livestock and feral burros as the most important disturbances contributing to severe declines in tortoise populations. Some cattle grazing allotments remain in critical habitat as of 2018 .

Long-term grazing in the desert results in reduction and loss of cover of shrubs and changes in the species composition of shrubs, favoring short-lived, weedy species (Webb and Steilstra 1979; Brooks et al. 2006). The composition and biomass of annual and perennial vegetation changes at sites where livestock concentrate: water sources, bedding areas, and loading and unloading areas (Webb and Steilstra 1979; Nicholson and Humphreys 1981; Brooks et al. 2006). Short-lived, colonizing shrubs and non-native grasses, tolerant of disturbances and inedible or less desirable as forage by livestock, are more common than in relatively undisturbed areas. Brooks et al. (2006) described piospheres, a disturbance gradient associated with watering sites for domestic grazers. Vegetation was denuded and soils compacted within 15 to $70 \mathrm{~m}$ of the tanks and troughs, with significant effects extending up to $200 \mathrm{~m}$ from the watering sites. Densities of the alien forb redstem filaree and alien Mediterranean grasses increased with increasing proximity to the water source, whereas native annuals decreased in cover and species richness with increasing proximity to the stock tank or other water sources. Cover and species richness of shrubs also decreased with increasing proximity to sources of water. Livestock prefer certain forbs, when they are available, and can rapidly deplete available favored food plants of the tortoise through trampling and foraging (Berry 1978, Webb and Stielstra
1978). The seedbank for native annuals and herbaceous perennials may also be reduced (Brooks 1995).

When livestock are moved from one place to another, whether in open desert or along stock driveways (e.g., Wentworth 1948), soils are disturbed and clouds of dust created. Importantly, stock tanks also are an attractant to and a subsidy used by ravens (Knight et al. 1998). Beschta et al. (2013) recommended removing or reducing livestock and feral burros and horses across public lands to make the lands less vulnerable to climate change.

Miners came to the Mojave and Colorado deserts seeking riches in the 1800s (e.g., Spears 1892; Vredenberg et al. 1981) and mining continues to be a source of loss, disturbance, and deterioration to tortoise habitat (e.g., Chaffee and Berry 2006; Kim et al. 2012, 2014). Early miners left pits, diggings, and shafts that trapped tortoises and that remain today; some shafts and pits are fenced and some are not.

Chaffee and Berry (2006), in an analysis of soil, stream sediments, and food plants of tortoises in the Mojave and Colorado deserts of California, reported anomalies in arsenic desert-wide.In the Rand and Atolia Mining Districts (Western Mojave Recovery Unit) they reported elevated levels in soil of arsenic, gold, cadmium, mercury, antimony, and/or tungsten $15 \mathrm{~km}$ from the mining source and plant anomalies for arsenic, antimony, and/or tungsten up to $6 \mathrm{~km}$ from the mining source. Elevated levels of mercury occurred as much as $6 \mathrm{~km}$ from old tailings piles. Arsenic and mercury were potential causes of illness in tortoises found in the area (Jacobson et al. 1991; Selzer and Berry 2005). Elevated levels of arsenic also occurred in the Goldstone Mining District and extended outward about $8 \mathrm{~km}$. The highest arsenic concentrations occurred in 13 species of plants, of which five were species of legumes favored by tortoises (e.g., Jennings and Berry 2015). Kim et al. (2012, 2014) reported fluvial and aeolian transport of arsenic from several mining communities (Western Mojave Recovery Unit). Fluvial transport of arsenic from mining tailings occurred (and still occurs) in pulses with episodic rain events, and, depending on location, extends to $15 \mathrm{~km}$ from the source. The authors described aolian transport to $6 \mathrm{~km}$ from the source and calculated the cancer exposure risk to humans. Elemental toxicants can enter tortoises through breathing dust, consumption of contaminated plants, and contact with the skin. Foster et al. (2009) identified endogenous sources of arsenic in both shell and lung tissues.

Invasive Plants. - As a result of the disturbances to soil and vegetation described above, tortoise habitats in the Mojave and Colorado deserts have become vulnerable to invasion and establishment of non-native (alien, exotic) plants from arid areas in the Mediterranean, North Africa, Middle East, and Asia. Changes in plant composition and structure, especially cover and selected forage plants, are great threats to remaining tortoises. Several authors (e.g., 
D'Antonio and Vitousek 1992; Kemp and Brooks1998) suggested that most exotic species arrived in the desert during the middle-to-late 18th century after the Gold Rush of 1849 and became established with livestock grazing and construction of roads and railroads. Later land-disturbing uses such as agriculture, ranching, settlements, cities, and towns were additional contributors (Brooks 2009).

The following non-native species of grasses and a forb composed most of the annual biomass in tortoise habitats in the early 2000s: Mediterranean grasses, red brome, cheat grass, and redstem filaree (Hunter 1991; Kemp and Brooks 1998), until the more recent appearance of Sahara mustard (Brassica tournefortii) (see below). In critical habitat within the Western Mojave Recovery Unit, non-native annuals composed 66\% of the annual biomass in wet years and $91 \%$ in dry years, and positive correlations existed between richness of alien annual plant species and density of dirt roads in a wet year and with nitrogen in the soil during a dry year (Brooks and Berry 2006). During a wet year, total alien biomass correlated positively with proximity to the nearest urban area or paved roads and area and numbers of recent fires. During a dry year, total alien biomass was negatively correlated with diversity of annuals and positively correlated with biomass of native annuals, and the history of off-highway, recreational vehicle use. Total alien annual biomass, especially grasses, correlated positively with numbers of fires and area burned between 1980 and 1994 within $5 \mathrm{~km}$ of sampled plots in both wet and dry years, likely due to the flammability of alien grasses. Further, Brooks $(2000,2003)$ found that non-native grasses were especially effective in competing with native forbs and the exotic forb redstem filaree.

Increased atmospheric nitrogen deposited in soils from urban or other areas enhances dominance of alien annual plants, which in turn contributes to increases in frequency of fires (e.g., Brooks 2003; Rao and Allen 2010). Rao et al. (2011) followed with additional studies, and reported that large-scale patterns in disturbance and exotic species negatively affected diversity of native annual plant species; native annuals persisted locally, however. Increases in atmospheric $\mathrm{CO}_{2}$, an effect and cause of global climate change, may enhance the long-term success and dominance of exotic annual grasses (e.g., red brome) in the Mojave Desert (Smith et al. 2000).

Seed banks reflected the status of habitat disturbance and invasion of alien species. At the Desert Tortoise Research Natural Area (fenced to exclude off-road vehicle use and grazing), Brooks (1995) reported that seed biomass was two to four times greater inside the fence than outside. Schneider and Allen (2012) noted that where invasions of non-natives were low, seeds of natives were in higher densities in seed banks. In high invasion sites, non-natives were higher in both seed banks and above-ground vegetation. Esque et al. (2010b) reported that invasive species (Mediterranean grasses, bromes, redstem filaree, and plantain, Plantago spp.) composed $>95 \%$ of the seed bank following experimental fires of moderate temperatures in the Parashant National Monument of Arizona.

The non-native and invasive Sahara mustard was observed first in the Colorado Desert in the 1920s (Minnich and Sanders 2000). Subsequently, it spread rapidly northward and westward into the Mojave Desert (museum records, Jepson Flora Project 2018; Berry, pers. obs.). It has invaded most Recovery Units and is well established desert-wide. It can grow up to $>1.5 \mathrm{~m}$ in height, produce large numbers of seeds, become a "tumble mustard" that can blow across landscapes, and appears to be a vigorous competitor of native annuals in the Mojave and western Sonoran deserts (Trader et al. 2006; Bangle et al. 2008; Barrows et al. 2009; Berry et al. 2014b). Sahara mustard is a highly successful invader that probably poses a considerable threat to native annuals because of early germination and rapid phenology, and its ability to disperse quickly across valleys and fans and in ephemeral stream channels (Bangle et al. 2008; Marushia et al. 2012; Suazo et al. 2012; Berry et al. 2014b). Desert Tortoises do not forage on Sahara mustard.

Fires. - Fires and invasive annual grasses are closely linked (D'Antonio and Vituosek 1992). Vegetation in the Mojave and western Sonoran deserts did not evolve with fire; occasional wildfires, ignited by lightning or campfires, occurred but were small because fuel was limited (Brooks and Chambers 2011). With the invasion and establishment of alien grasses, fuels became available and created an unnatural and destructive grass-fire cycle in which fires increased in frequency and area, potentially in intensity, and were followed by regrowth of the alien grasses (D'Antonio and Vitousek 1992; Brooks and Matchett 2006).

According to D'Antonio and Vitousek (1992), the invasion of cheat grass and associated fires was the most significant plant invasion in North America. Mediterranean grasses and red brome also play important roles and have different rates of fire spread across interspaces-slowly and discontinuously with Mediterranean grasses and more rapidly and continuously with bromes (Brooks 1999). The results suggested that red brome and cheat grass fueled faster moving, hotter fires, while Mediterranean grasses fueled slower moving, cooler fires.

Fires increased in frequency between 1980 and 2004 across the Mojave and Colorado deserts in critical habitat and in California (Brooks and Esque 2002; Brooks and Matchett 2006). The latter authors reported that 8,699 fires burned 2,920 $\mathrm{km}^{2}$ between 1980 and 2004. Most fires occurred in shrub associations at middle elevations where typical tortoise habitat occurs, e.g., creosote bush, Joshua tree, and blackbrush vegetation associations. In 2005, a total of 576 $\mathrm{km}^{2}$ burned in the northeastern Mojave Desert and Upper 
Virgin River (USFWS 2010). The percentages of critical habitat burned varied: $3 \%$ of Mormon Mesa, $13 \%$ of Gold Butte-Pakoon, 25\% of Beaver Dam Slope in the Northeastern Mojave Recovery Unit, and 19\% of the Upper Virgin River Recovery Unit. Many tortoises died, but numbers were not provided in the USFWS (2010) report. According to Brooks and Matchett (2006), the trend from the 1990s and on for human-caused fires was toward a decreasing number of ignitions and a greater area burned.

Burned habitat affects the tortoises living there. Drake et al. (2015) studied how tortoises respond when about $45 \%$ of their home ranges were burned after a lightning-caused fire. They traveled increasingly deeper into the burned area to forage during the first 5 years post-fire, but returned to the unburned area for cover. One of the important forage plants common after the burn, globemallow, declined 6-7 years after the burn. At that time, tortoises reduced use of the burned area. In spite of damage from the fire, tortoises maintained reproductive output and health during the study. Lovich et al. (2018a) compared populations of tortoises in burned and unburned areas after a wind turbine fire; tortoises in the burned area continued use of the same activity areas after the fire.

Briefly, the many sources of habitat loss and degradation continue to have profound negative effects on the diversity, composition, and biomass of native annual and herbaceous perennial forbs and perennial shrubs and, importantly, the food supply and cover of shrubs essential for continued survival of G. agassizii. This pattern of changes and loss to the flora are not confined to the tortoise (Minnich 2008).

Climate Change and Projected Effects. - Global warming and changes in rainfall patterns are added negative impacts (Seager et al. 2007, Garfin et al. 2014; Allen et al. 2018; Sarhadi et al. 2018) and are likely to have severe effects on remaining, declining, and fragmented Desert Tortoise populations. The U.S. Global Change Research Program (USGCRP 2017) has predicted increased drying with reduced winter and spring precipitation in the American Southwest. Reduced precipitation in winter and spring (droughts) and higher temperatures contribute to deterioration in composition, structure, diversity, and biomass of trees and shrubs (Munson et al. 2016). Annual and herbaceous perennial plants would be similarly affected. Forage of native food plants is likely to become more limited in dry years (see Brooks and Berry 2006).

Models of the effects of climate change and warming on tortoises at the Mojave-Sonoran interface indicated that some available habitat will be lost (Barrows 2011). Tortoises may respond by shifting distribution to higher elevations and away from the western Sonoran Desert if they have time and opportunity to do so. With increasing droughts, survival of tortoises is likely to be severely reduced (e.g., Berry etal.2002; Longshore et al.2003; Lovich et al.2014b).
Climate refugia can be modeled to identify areas where existing populations may survive at warmer temperatures and where tortoises may be successfully translocated (Barrows et al. 2016). Such models will need to take into account the prediction "that the risk of American Southwest megadroughts will markedly increase with global warming" (Steiger et al. 2019).

Consequences of Fragmentation. - The many land uses described above have resulted in degradation, fragmentation, and loss of connectivity between populations within the metapopulation of G. agassizii. As habitat fragments become smaller and increasingly isolated, they become more vulnerable to increased genetic drift and inbreeding, reduction of genetic variation, and decrease in heterozygosity - an extinction vortex (Gilpin and Soulé 1986; Fagan and Holmes 2006). With the rapid decline in densities of tortoises in critical habitat units between 2004 and 2014, and the non-viability of many populations in critical habitat (USFWS 1994, 2011), the remaining populations are increasingly vulnerable to additional disturbances, long periods of drought, and catastrophic events. The impacts and demands of rapidly expanding human populations across the geographic range add to the severity of the problem (Hughson 2009).

Recovery of Habitat after Disturbance. - Tortoise habitats are likely to require centuries, if not thousands of years for recovery. Creosote bushes, a prominent species in tortoise habitat, form long-lived clones in the Mojave Desert and some very large clones are estimated to be as much as 11,700 years old (Vasek 1980). Over the past approximately 70 years, scientists have investigated how quickly vegetation can recover naturally after disturbances in creosote bush associations in the Mojave and Sonoran deserts. Most studies in tortoise habitats focused on natural recovery of shrubs (with minimal interventions) after disturbances from pipelines, aqueducts, borrow pits, and old military activities (e.g., Lathrop and Archbold 1980a,b; Vasek et al. 1975a,b; Prose et al. 1987; Abella 2010; Berry et al. 2016b). The composition of perennial shrubs goes through successional stages in the recovery process. Estimates for the time required for recovery to pre-disturbance values for canopy cover of shrubs may be decades, whereas a return to pre-disturbance levels for floristic structure and composition may require centuries.

Few publications exist on natural and enhanced recovery of communities of native annual and herbaceous perennial species after different types of disturbances (Johnson et al. 1975; Vasek 1979, 1980, 1983; Hessing and Johnson 1982; Prose and Wilshire 2000; Berry et al. 2015b). Vasek (1983) suggested that "some constellations of annual species may be members of stable old communities [referencing creosote bush scrub associations] and therefore probably have evolved intricate highly integrated adaptations for long persistence 
in stable desert conditions." Estimated recovery times for cover, floral composition, density, and biomass of annuals vary, but are likely to be much longer than for shrubs, depending on causes of disturbance, treatment and types of the soils, and whether or not non-native grasses and forbs are present. Berry et al. (2015b) concluded that return to pre-disturbance levels may require many centuries in their study of annuals recovering after 36 years of disturbance along a utility corridor in the western Mojave Desert. During the recovery process, annual communities may go through several seral stages (Hessing and Johnson 1982; Berry et al. 2015b).

Cumulative and Synergistic Impacts. - We have reviewed numerous causes of declines and how many of these causes are linked to each other and to human activities. In response to requests from managers to identify the most important cause(s), some scientists have quantified and modelled negative impacts in specific areas (e.g., Keith et al. 2008; Berry et al. 2008,2014a; Tuma et al.2016). Berry et al. (2014a) reported that in critical habitat with recent exclusion of livestock, limited vehicular traffic, and a partial fence, tortoise abundance (counts of live and dead tortoises and tortoise sign) was negatively associated with vehicle tracks and positively associated with mammalian predators and debris from firearms. Tuma et al. (2016) modelled severity of population decline rates at two sites, one in the central Mojave Desert and another in the northeastern Mojave Desert. In the central Mojave Desert, models indicated that the most severe decline rates were associated with human presence, followed by subsidized predators, and habitat degradation on inholdings. In contrast, in the northeastern Mojave Desert (Gold-Butte Pakoon critical habitat), livestock and feral burros were associated with the most significant declines, followed by human presence, subsidized predators, and wildfires.

Conservation Measures Taken. - Gopherus agassizii has been listed as federally Threatened under the U.S. Endangered SpeciesAct(USESA) since 1990.It was assessed as Vulnerable for the IUCN Red List in 1996 and provisionally re-assessed for the Red List as Critically Endangered by the IUCN Tortoise and Freshwater Turtle Specialist Group in 2011 and again in 2018 (TCC 2018; Rhodin et al. 2018). It has been listed on Appendix II of CITES (2017) since 1975 as part of the genus listing of Gopherus, and since 1977 as part of the family listing of Testudinidae.

Gopherus agassizii occurs in several areas with some degree of protection. The Desert Tortoise Research Natural Area in California is the most protected, followed by the Red Cliffs Desert Reserve in Utah. Limited protection is available in three national parks, especially in remote areas and where suitable habitat exists (Joshua Tree National Park and Mojave National Preserve in California, and Death Valley National Park in California and Nevada) and eight state parks
(Red Rock Canyon State Park, Anza Borrego State Park, and Providence Mountains State Recreation Area in California; Red Rock Canyon National Recreation Area, Valley of Fire State Park, Lake Mead National Recreation Area, and the Desert National Wildlife Range in Nevada; and Snow Canyon in Utah). None of the national or state parks protect tortoises from paved or dirt roads with exclusion fencing, and at least one of the national parks (Mojave National Preserve) still maintains a cattle grazing allotment and feral burros within critical habitat.

Tortoises in parks with heavy visitor use are vulnerable to collecting and vandalism and road kills (e.g., Berry et al. 2008; Hughson and Darby 2013). For example, Mojave National Preserve contains two critical habitat units (Ivanpah and Fenner); in both, tortoise populations are declining (Table 3). Visitor use in the Preserve between 2004 and 2018 ranged from 537,250 to a high of 787,404 per year in 2018. In contrast, Joshua Tree National Park had a low density of tortoises, but the population was increasing (Table 3); visitor use in the Park was 2,942,382 in 2018. Lake Mead National Recreation Area has had over one million visitors per year since 1946 and growing; in 2018, 7.6 million visits occurred.

As noted in the section on Threats, the State of California took incremental protective measures for tortoises beginning in 1939. Grass-roots efforts advocating greater protection for a site with high densities began in the early1970s with the establishment of the Desert Tortoise Research Natural Area in the western Mojave Desert. The formation of the Desert Tortoise Preserve Committee, Inc. and Desert Tortoise Council, two non-profit, tax-exempt organizations, occurred about 1976. The Desert Tortoise Preserve Committee focuses efforts on public education, land acquisition and protection, fencing of protected areas, removing livestock grazing and recreational vehicle use from the Desert Tortoise Research Natural Area and other acquired lands, and research. The Desert Tortoise Council's goals and objectives include education through annual symposia and workshops, grants for travel and studies, and participation in government activities affecting tortoises and their habitats. Both organizations have promoted state and federal listings of the tortoise as a Threatened species. After the Beaver Dam Slope population of Desert Tortoises was federally listed as Threatened in 1980 under the U.S. Endangered Species Act (USFWS 1980), the Desert Tortoise Council submitted a comprehensive report to the U.S. Fish and Wildlife Service in 1984 to also list the tortoise throughout its range (Berry 1984). Studies and research on the tortoise and its habitats, supported by federal and state agencies and academia, began in the early 1970s and continued intermittently thereafter.

In 1980, the U.S. Bureau of Land Management, the agency managing substantial amounts of tortoise habitat 
range-wide, published the California Desert Plan, 1980. The Plan described the Desert Tortoise as a sensitive species, identified several crucial habitats (precursors to critical habitat units), established Areas of Critical Environmental Concern for the tortoise, and outlined expansive areas for future habitat management plans for the species (USBLM 1980). The Desert Tortoise Research Natural Area was formally designated in this Plan, a protective fence surrounding the area and a kiosk for visitors were completed, and a long-term mark-recapture study was initiated. In 1989, California designated the Desert Tortoise as a Threatened species (California Department of Fish and Wildlife 2016). The U.S. Fish and Wildlife Service listed the tortoise as Endangered on an interim basis in August of 1989 and issued a final rule as Threatened in April of 1990 (USFWS 1990). The U.S. Fish and Wildlife Service published a Recovery Plan in 1994 and designated > 25,000 $\mathrm{km}^{2}$ of critical habitat units north and west of the Colorado River in the same year (USFWS 1994). In response to the pending listing and designation of critical habitat, federal, state, and county governments formed a Management Oversight Group composed of senior managers who address a wide variety of topics associated with recovery of the species at meetings held at least once a year.

The 1994 Recovery Plan contained numerous recommended management actions for Desert Wildlife Management Areas (defined as the best examples of Desert Tortoise habitat within regions): secure habitat, develop and implement reserve-level management, monitor tortoise populations within recovery areas, and develop environmental education programs (USFWS 1994). Several examples highlight recommended regulations and activities to be prohibited: all vehicle activity off designated roads and all competitive and organized events on designated roads; habitat-destructive surface disturbance that diminishes capacity of land to support tortoises; domestic livestock grazing and grazing by feral burros and horses; vegetation harvest, except by permit; collection of biological specimens, except by permit; dumping and littering; deposition of captive or displaced tortoises except under authorized translocation research projects; uncontrolled dogs out of vehicles; and discharge of firearms, except for hunting of game from September through February. The recommended actions included the following: control vehicular access; enforce regulations, restore disturbed areas; sign and fence Desert Wildlife Management Areas; implement appropriate administration; modify ongoing and planned activities to be consistent with recovery objectives; control use of landfills and sewage ponds by predators of tortoises; and establish environmental education programs and facilities.An important recommendation was to monitor tortoise populations in critical habitat units at a landscape scale. This latter effort was initiated in 1999 and the early 2000s, e.g., Table 3.
Government agencies responded to the Recovery Plan by preparing nine new or revised land management plans to better protect the Desert Tortoise on public lands (Berry 1997). Additional plans on military installations were revised or amended to include the Desert Tortoise. In 2011, the USFWS published a revised Recovery Plan which incorporated many actions described in the first Recovery Plan (USFWS 1994, 2011). The revised Recovery Plan described numerous recommendations for future research. One important issue, hyper-predation by ravens, was the topic of a special plan, which has involved surveys, selected removal of limited numbers of ravens, and egg-oiling (USFWS 2008). Part of the revised Recovery Plan was development of regional Recovery Implementation Teams composed of representatives from government agencies and non-profit organizations. Participants in these teams prepare proposals for recovery actions, seek funding to support the proposals, and assist with implementation when funding becomes available.

In the nearly 30 years since the Desert Tortoise was first listed range-wide in 1990, much has been accomplished by changes in land use. Unfortunately, positive actions have remained insufficient in amount and extent to stabilize tortoise populations in the designated critical habitat units (USFWS 2015; Table 3; Allison and McLuckie 2018). Land acquisition for the Desert Tortoise Research Natural Area, which began in the late 1970s, has continued.The U.S.Bureau of Land Management and other government agencies and conservation organizations have acquired substantial amounts of private lands in small and large parcels to convert critical habitat and other protected areas to federal and conservation management.

Sheep grazing has been removed from critical habitat, but cattle continue to graze on about $17 \%$ of critical habitat, and feral burros encroach on a few critical habitat units. Tortoise-exclusion fencing was constructed along many kilometers of roads; however, as of 2010, thousands of kilometers of roads and railroads remained unfenced (USFWS 2010). Experimental efforts to reduce vehicle speed on roads within the Mojave National Preserve to reduce road kills were unsuccessful (Hughson and Darby 2013). One of the more intractable problems is the high density of routes and tracks created by recreational vehicle use, the high levels of unauthorized and cross-country travel on 2- and 4-wheeled vehicles, and the negative effects on tortoises and their habitats (Goodlett and Goodlett 1992; Egan et al. 2012; Piechowski 2015; USBLM 2019).

The federal (and state) listings of the Desert Tortoise as Threatened stimulated a great deal of interest and effort in addressing basic questions about the species, such as status and distribution of populations, ecology, genetics, and diseases, as well as solving conflicts with the many users of Desert Tortoise habitats. Conflicts existed over 
degradation of habitat and threats to Desert Tortoises from historical users (livestock grazing, mining, and recreation), developers, and some government agencies. Other agencies, academicians, and non-profit organizations held more conservation-oriented views. As a result, many basic and applied research projects were undertaken and completed, and the results were published in peer-reviewed journals between 1980 and 2018 (Grover and DeFalco 1995; >400 published papers, Berry et al. 2016c). Notably, many agencies and developers provided substantial funds to support studies and research, e.g., U.S. Department of the Interior (U.S. Bureau of Land Management, U.S. Geological Survey), U.S. Department of Defense (Army, Air Force, Marines), California Department of Fish and Game, California Department of Parks and Recreation, California Energy Commission, Utah Division of Wildlife Resources, and several universities. Many other entities also provided funds but not on the same scale.

Two current conservation research topics are augmentation of populations through head-starting and translocation. Experimental research has been conducted and continues in four desert regions on head-starting to learn more about neonates and juveniles and their habitat requirements, to determine factors affecting survival both before and after release, and to augment depleted populations (e.g., Morafka et al. 1997; Wilson et al. 1999a,b, 2001; Nagy et al. 2015a,b, 2016; Todd et al. 2016; Mack et al. 2018). However, caution needs to be exercised, as some research manipulations, such as crowding in head-start pens and cystocentesis of adults, can lead to increased morbidity and mortality (Berry et al. 2002; Mack et al. 2018).

Translocations to remove Desert Tortoises from areas scheduled for development continue and are important research topics (e.g., Field et al. 2007; Nussear et al. 2012; Farnsworth et al. 2015; Hinderle et al. 2015; Brand et al. 2016; Nafus et al. 2016; Mulder et al. 2017; Henen 2018). Most research topics on translocation were short term (1-3 years). The research undertaken by Farnsworth et al. (2015), Brand et al. (2016), and others were for short-distance translocations covering five years. When all elements of this study are published, they will provide a valuable addition to the topic. Publications preparatory for and during mixed long and short-distance translocations include Esque et al. (2010a), Berry et al. (2015a), and Mulder et al. (2017). When these longer-term projects (10 years) are published, more information will be available on survival of translocated animals. In an important paper, Mulder et al. (2017) reported on genetic integration of tortoises translocated long distances. After four years, translocated males produced significantly fewer off-spring than resident males in the same area. The length of delay in integration of translocated males into resident populations needs to be addressed through future research.
Another important recovery objective is restoration of disturbed and burned Desert Tortoise habitats (e.g., Abella 2010; Abella and Newton 2009; Abella and Berry 2016; Abella et al. 2009, 2015a,b). Topics being addressed include methods for salvaging soils and seed banks, restoring seed banks of native plants, improving survival of shrubs after seeding and planting, keeping transplanted shrubs alive and growing, and planting forage species for tortoises.

Conservation Measures Proposed. - Most of the $>400$ papers published on Desert Tortoises and their habitats after the federal listing in 1990 contained recommendations for recovering the tortoise and its habitats (Berry et al. 2016c). The revised Recovery Plan also contains a list of recovery actions to be taken, including development of partnerships to facilitate recovery, protection of existing populations and habitat, augmenting depleted populations, conducting applied research and modeling, and implementing an adaptive management program (USFWS 2011). The Recovery Implementation Teams have submitted projects for restoration of burned habitats and areas denuded by livestock, management of trash (a source of food for subsidized predators), control of invasive plants, fencing of major highways, and many other topics.

Research on genetics of tortoises provides a framework for changes in management. The most detailed genetic analyses of tortoise populations published to date (Sánchez-Ramírez et al. 2018) provided data on population differences within and between recovery units, as well as identification of 12 genes likely involved in adaptations. The results of this paper suggested that the Western Mojave Recovery Unit could defensibly be divided into three separate Recovery Units: western, central, and southern, since these three subunits are genetically equivalent to each of the other four Recovery Units. The results also suggested that it could be valuable to update Averill-Murray and Hagerty (2014), who had used Hagerty and Tracy (2010) and Hagerty et al. (2011) as a basis to suggest that tortoises could be translocated within a 200-276 km straight-line radius of their native sites without moving animals between different genetic subunits. The results of Sánchez-Ramírez et al. (2018) suggested that caution is warranted when implementing such a practice, since such distances may involve different genetic units or subunits.

Another publication by Drake et al. (2017) coupled standard clinical and classic blood diagnostics with gene transcription profiles in ill and normal tortoises. These findings indicate promise for more robust diagnostic procedures in evaluating ill and healthy tortoises and for tortoises subjected to disturbances. Publications of the genome sequences for G. agassizii and Mycoplasma testudineum provide a basis for further advances in diagnostic procedures (Tollis et al. 2017; Weitzman et al. 2018), with Weitzman et al. (2017) offering another example through a comparison of different 
testing techniques for the pathogen M. agassizii with rangewide sampling.

Captive Husbandry. - Captive husbandry falls into two categories: research associated with head-starting and augmenting wild populations (see above), and management of tortoises kept as pets, in many cases for decades. In California, 13 chapters of the California Turtle and Tortoise Club manage adoption programs for domestic or pet G.agassizii and other chelonian species under agreements with the California Department of Fish and Wildlife (https://tortoise. org/). In Nevada, this function is accomplished by Tortoise Group (https://tortoisegroup.org/). These organizations (and others) provide information on husbandry, state and federal regulations, and education.

Current Research. - Research on basic ecology, demography, and distribution continues, as does indepth work on genetics, infectious and other diseases, epidemiology of diseases, effects of anthropogenic activities on tortoises, augmentation of populations, and effects of drought and global climate change. Updates on modelling viability of populations, survival rates of the different size classes, and causes of death are important building blocks for recovery strategies and adaptive management. Ongoing applied research focuses on a wide array of topics, such as effectiveness of different augmentation strategies, including head-starting and translocation, control and management of subsidized predators, and restoration of habitats degraded by livestock grazing, recreational vehicle use, and industrial and energy developments. The effects of different anthropogenic impacts on tortoises remain an area of interest. New technologies (e.g., drones) are also areas of interest.

Acknowledgments. - Thanks are due to the hundreds of scientists who have conducted and published studies and research designed to address basic natural history, ecology, and health of Desert Tortoises, as well as the many drivers of anthropogenic impacts. Mark Massar, Jeff Aardahl, and Debra Hughson provided answers to our many questions about ongoing activities. We thank Betty L. Burge, Steve Ishii, Mark Massar, Ann McLuckie, Freya Reder, Cameron Rognan, Bev Steveson, Michael Tuma, Desert Tortoise Preserve Committee, Mojave Natural Preserve, San Diego Zoo Global, and U.S. Geological Survey for the use of their photos. Anders Rhodin improved the manuscript with his editing, and reviews from John Iverson, Peter Paul van Dijk, Taylor Edwards, Diane Elam, Keith Miles, and Barbara Ralston were constructive and added to the paper.

\section{LITERATURE CITED}

Abella, S.R. 2008. A systematic review of wild Burro grazing effects on Mojave Desert vegetation, USA. Environmental Management 41:809-819.
Abella, S.R. 2010. Disturbance and plant succession in the Mojave and Sonoran deserts of the American Southwest. International Journal of Environmental Research and Public Health 7:1248-1284.

Abella, S.R. And Newton, A.C. 2009. A systematic review of species performance and treatment effectiveness for revegetation in the Mojave Desert, USA. In: Fernandez-Bernal, A. and De La Rosa, M.A. (Eds.). Arid Environments and Wind Erosion. Nova Science Publishers, Inc., pp. 46-74.

Abella, S.R. AND Berry, K.H. 2016. Enhancing and restoring habitat for the Desert Tortoise Gopherus agassizii. Journal of Fish and Wildlife Management 7:1-25.

Abella, S.R., Spencer, J.E., Hoines, J., and Nazarchyk, C. 2009. Assessing an exotic plant surveying program in the Mojave Desert, Clark County, Nevada, USA. Environmental Monitoring and Assessment 151:221-230.

Abella, S.R., Chiquoine, L.P., Newton, A.C., and Vanier, C.H. 2015a. Restoring a desert ecosystem using soil salvage, revegetation, and irrigation. Journal of Arid Environments 115:44-52.

Abella, S.R., Chiquoine, L.P., Engle, E.C., Kleinick, K.E., And EDWARDS, F.S. 2015b. Enhancing quality of Desert Tortoise habitat: augmenting native forage and cover plants. Journal of Fish and Wildlife Management 6:278-289.

Adams, J.A., Endo, A.S., Stolzy, L.H., Rowlands, P.G., And Johnson, H.B. 1982. Controlled experiments on soil compaction produced by off-road vehicles in the Mojave Desert, California. Journal of Applied Ecology 19:167-175.

Agha,M.,Lovich,J.,Ennen,J., And Wilcox,E.2013.Nest-guarding by female Agassiz's Desert Tortoise (Gopherus agassizii) at a wind-energy facility near Palm Springs, California. Southwestern Naturalist 58:256-260.

Agha, M., Augustine, B., Lovich, J.E., Delaney, D., Sinervo, B., Murphy, M.O., Ennen, J.R., Briggs, J.R., CoOper, R., And PRICE, S.J. 2015a. Using motion-sensor camera technology to infer seasonal activity and thermal niche of the Desert Tortoise (Gopherus agassizii). Journal of Thermal Biology 49-50:119-126.

Agha, M., Murphy, M.O.,Lovich, J.E., Ennen, J.R., Oldham, C.R., Meyer, K., Buurlin, C., Austin, M., Madrak, S., Loughran, C., Tennant,L., AND Price, S.J.2015b. The effect of research activities and winter precipitation on voiding behavior of Agassiz's Desert Tortoises (Gopherus agassizii). Wildlife Research, http://dx.doi. org/10.1071/WR14196

Agha, M., Lovich, J.E., Ennen, J.R., Augustine, B., Arundel, T.R., Murphy, M.O., Meyer-Wilkins, K., Buurlin, C., Delaney, D., Briggs, J., Austin, M., Madrak, S.V., and Price, S.J. 2015c. Turbines and terrestrial vertebrates: variation in tortoise survivorship between a wind energy facility and an adjacent undisturbed wildland area in the desert Southwest (USA). Environmental Management 56:332-341.

Agha, M., Smith, A.,Lovich, J.E., Delaney, D.,Ennen, J.R., Briggs, Fleckenstein, L.J., Tennant, L.A., Puffer, S.R., Walde, A., Arundel, T.R., Price, S.J., And TodD, B.D. 2017. Mammalian mesocarnivore visitation at tortoise burrows in a wind farm. Journal of Wildlife Management 81:1117-1124.

Aiello, C.M.,Nussear, K.W.,Esque, T.C., Emblidge, P.G., Sah, P., Bansal, S., ANd Hudson, P.J. 2016. Host contact and shedding patterns clarify variation in pathogen exposure and transmission in threatened tortoise Gopherus agassizii: implications for disease modelling and management. Journal of Animal Ecology, https:// doi:10.1111/1365-2656.12511.

Aiello, C.M., Esque, T.C., Nussear, K.E., Emblidge, P.G., And 
Hudson, P.J. 2018. The slow dynamics of mycoplasma infections in a tortoise host reveal heterogeneity pertinent to pathogen transmission and monitoring. Epidemiology and Infection 1-10, https://doi.org/10.017/S0950268818002613.

Alberts, A.C., Rostal, D.C., And Lance, V.A. 1994. Studies on the chemistry and social significance of chin gland secretions in the Desert Tortoise, Gopherus agassizii. Herpetological Monographs 8:116-124.

Allen, M., Babiker, M., Chen, Y., De Coninck, H., Connors, S., van Diemen, R., Dube, O.P., ET AL. 2018. Global warming of $1.5^{\circ} \mathrm{C}$, an Intergovernmental Panel on Climate Change Special Report on the impacts of global warming of $1.5^{\circ} \mathrm{C}$ above pre-industrial levels and related global greenhouse gas emission pathways, in the context of strengthening the global response to the threat of climate change, sustainable development, and efforts to eradicate poverty. Summary for Policymakers. Approved and accepted by the 48th Session of the IPCC, Incheon, Republic of Korea, 6 October 2018.

Allison, L.J. AND McLuckie, A.M. 2018. Population trends in Mojave Desert Tortoises (Gopherus agassizii). Herpetological Conservation and Biology 13:433-452.

Andersen, M.C., Watts, J.M.,Freilich, J.E., Yool, S.R., Wakefield, G.I., McCauley, J.F., and Fahnestock, P.B. 2000. Regressiontree modeling of Desert Tortoise habitat in the central Mojave Desert. Ecological Applications 10:890-900.

ANDERSON,K. AND BERRY, K.H.2019. Gopherusagassizii(Agassiz's Desert Tortoise). Predation. Herpetological Review 50:351.

Andrew, N.G., Bleich, V.C., Morrison, A.D., LesickA, L.M, AND Cooley, P.J. 2001. Wildlife mortalities associated with artificial water sources. Wildlife Society Bulletin 29:275-280.

Anonymous. 1881. A water carrying tortoise. San Francisco, CA: Mining and Scientific Press, Dewey and Co., p. 320.

AnONymous (StAFF And Wire Reports). 2018. Wildlife officials find non-native tortoises in Red Cliffs Desert Reserve. St. George Spectrum and Daily News, Oct. 21, 2018 online.

AufFEnBERG, W. And Franz, R. 1978. Gopherus agassizii.Catalogue of American Amphibians and Reptiles 212.1-212.2.

Averill-Murray, R.C. AND Hagerty, B.E. 2014. Translocation relative to spatial genetic structure of the Mojave Desert Tortoise, Gopherus agassizii. Chelonian Conservation and Biology 13:35-41.

Averill-Murray, R.C., Darst, C.R., Stout, N., and Wong, M. 2013. Conserving population linkages for the Mojave Desert Tortoise (Gopherus agassizii). Herpetological Conservation and Biology 8:1-15.

Avery, H.W. And Neibergs, A. 1997. Effects of cattle grazing on the Desert Tortoise, Gopherus agassizii: nutritional and behavioral interactions. In: Van Abbema, J. (Ed.). Proceedings: Conservation, Restoration, and Management of Tortoises and Turtles-An International Conference. New York: New York Turtle and Tortoise Society and the WCS Turtle Recovery Program, pp. 13-20.

Bangle, D.N., Walker, L.R., And Powell, E.A. 2008. Seed germination of the invasive plant Brassica tournefortii (Sahara mustard) in the Mojave Desert. Western North American Naturalist 68:334-342.

BARrow, J. 1979. Aspects of the ecology of the Desert Tortoise, Gopherus agassizii, in Joshua Tree National Monument, Pinto Basin, Riverside County, California. Desert Tortoise Council Symposium Proceedings 1979:105-131.

Barrows, C.W. 2011. Sensitivity to climate change for two reptiles at the Mojave-Sonoran Desert interface. Journal of Arid Environments 75:629-635.
Barrows, C.W.,Allen, E.B., Brooks, M.L., And Allen, M.F. 2009. Effects of an invasive plant on a desert sand dune landscape. Biological Invasions 11:673-686.

Barrows, C.W., Henen, B.T., and Karl, A.E. 2016. Identifying climate refugia: a framework to inform conservation strategies for Agassiz's Desert Tortoise in a warmer future. Chelonian Conservation and Biology 15:2-11.

BAtTYE,C. 1924.An episode of the early days at Needles, California. Santa Fe Magazine 28:37-39.

BAXter, P.C., Wilson, D.S., AND MorafKa, D.J. 2008. The effects of nest date and placement of eggs in burrows on sex ratios and potential survival of hatchling Desert Tortoises, Gopherus agassizii. Chelonian Conservation and Biology 7:52-59.

BECK, D.D. 1990. Ecology and behavior of the Gila Monster in southwestern Utah. Journal of Herpetology 24:54-68.

BerRy, K.H. 1978. Livestock grazing and the Desert Tortoise. Transactions of the 43rd North American Wildlife and Natural Resources Conference, Wildlife Management Institute, Washington, DC.

BERRY,K.H.(ED.) 1984. The Status of the Desert Tortoise (Gopherus agassizii) in the United States. Report to the U.S. Fish and Wildlife Service from the Desert Tortoise Council on Order No. 11310-0083-81.

BERRY, K.H. 1986. Incidence of gunshot deaths in Desert Tortoises in California. Wildlife Society Bulletin 14:127-132.

BERRY,K.H. 1997.The Desert Tortoise Recovery Plan: an ambitious effort to conserve biodiversity in the Mojave and Colorado Deserts of the United States. In: Van Abbema, J. (Ed.). Proceedings: Conservation, Restoration, and Management of Tortoises and Turtles - An International Conference. N.Y. Turtle and Tortoise Society, pp. 430-440.

Berry, K.H. AND Christopher, M.M. 2001. Guidelines for the field evaluation of Desert Tortoise health and disease. Journal of Wildlife Diseases 37:427-450.

Berry, K.H. And Medica, P. 1995. Desert Tortoises in the Mojave and Colorado deserts. In: LaRoe, E.T., Farris, G.S., Puckett, C.E., Doran, P.D., and Mac, M.J. (Eds.). Our Living Resources. A Report to the Nation on the Distribution, Abundance, and Health of U.S. Plants, Animals, and Ecosystems. Washington, DC: U.S.Department of the Interior, National Biological Service, pp. 135-137.

BERRY, K.H. AND TuRnER, F.B. 1986. Spring activities and habits of juvenile Desert Tortoises, Gopherus agassizii, in California. Copeia 1986:1010-1012.

Berry, K.H., Shields, T., Woodman, A.P., Campbell, T., Roberson, J., Bohuski, K., AND KarL, A. 1986. Changes in Desert Tortoise populations at the Desert Tortoise Research Natural Area between 1979 and 1985. Desert Tortoise Council Symposium Proceedings 1986:100-123.

Berry, K.H., HoOver, F.G., AND WalKer, M. 1996. The effects of poaching Desert Tortoises in the western Mojave Desert: evaluation of landscape and local impacts. Desert Tortoise Council SymposiumProceedings 1996:45, http://www.deserttortoise.org.

Berry, K.H., Spangenberg, E.K., Homer, B.L., and Jacobson, E.R. 2002. Deaths of Desert Tortoises following periods of drought and research manipulations. Chelonian Conservation and Biology 4:436-448.

Berry, K.H., BaILEy, T.Y., AND ANDERSON, K.M. 2006. Attributes of Desert Tortoise populations at the National Training Center, Central Mojave Desert, California, USA. Journal of Arid Environments 67 (Supplement):165-191.

Berry, K.H., KeIth, K., And BaILEy, T. 2008. Status of the Desert Tortoise in Red Rock Canyon State Park. California Fish and 
Game 94:98-118.

Berry, K.H., Yee, J.L., Coble, A.A., Perry, W.M., And Shields, T.A. 2013. Multiple factors affect a population of Agassiz's Desert Tortoise (Gopherus agassizii) in the northwestern Mojave Desert. Herpetological Monographs 27:87-109.

Berry, K.H., Lyren, L.L., Yee, J.L., and Bailey, T.Y. 2014a. Protection benefits Desert Tortoise (Gopherus agassizii) abundance: the influence of three management strategies on a threatened species. Herpetological Monographs 28:66-92.

Berry,K.H.,Gowan, T.A., Miller, D.M., AND BroOKs, M.L. 2014 b. Models of invasion and establishment for African mustard (Brassica tourneforti). Invasive Plant Science and Management 7:599-616.

Berry, K.H., Coble, A.A., Yee, J.L., Mack, J.S., Perry, W.M., Anderson, K.M., AND Brown, M.B. 2015a. Distance to human populations influences epidemiology of respiratory disease in Desert Tortoises. Journal of Wildlife Management 79:122-136.

Berry, K.H., Mack, J.S., Weigand, J.F., and Gowan, T.A. 2015b. Bidirectional recovery patterns of Mojave Desert vegetation in an aqueduct pipeline corridor after 36 years: II. Annual plants. Journal of Arid Environments 122:141-153.

Berry, K.H., Shields, T., And Jacobson, E.R. 2016a. Gopherus agassizii (Mohave Desert Tortoise). Probable Rattlesnake envenomation. Herpetological Review 47:652-653.

Berry, K.H., Weigand, J.F., Gowan, T.A., and Mack, J.S. 2016 b. Bidirectional recovery patterns of Mojave Desert vegetation in an aqueduct pipeline corridor after 36 years: I. Perennial shrubs and grasses. Journal of Arid Environments 124:413-425.

Berry, K.H., Lyren, L.M., Mack, J.S., Brand, L.A., And Wood, D.A.2016c. Desert Tortoise Annotated Bibliography, 1991-2015. U.S. Geological Survey Open File Report 2016-1023, http:// dx.doi.org/10.3133/ofr20161023.

Beschta, R.L., Donahue, D.L., DellaSala, D.A., Rhodes, J.J., Karr, J.R., O'Brien, M.H., Fleischner, T.L., and Williams, C.D. 2013. Adapting to climate change on western public lands: addressing the ecological effects of domestic, wild, and feral ungulates. Environmental Management 41:474-491.

Buturlin, C.D. And Bissonette, J.A. 2004. Survival during early life stages of the Desert Tortoise (Gopherus agassizii) in the southcentral Mojave Desert. Journal of Herpetology 38:527-535.

BOARMAN, W.I. 1993. When a native predator becomes a pest: a case study. In: Majumdar, S.K., Miller, E.W., Baker, D.E., Brown, E.K., Pratt, J.R., and Schmalz, R.F (Eds.). Conservation and Resource Management. The Pennsylvania Academy of Science, pp. 191-206.

BoARMAn, W.I. AND BerRy, K.H. 1995. Common Ravens in the southwestern United States, 1968-92. In: LaRoe, E.T., Farris, G.S., Puckett, C.E., Doran, P.D., and Mac, M.J. (Eds.). Our Living Resources. A Report to the Nation on the Distribution, Abundance, and Health of U.S.Plants, Animals, and Ecosystems. Washington, DC: U.S. Department of the Interior, National Biological Service, pp. 73-75.

BoARman, W.I AND SAZAKI, M. 2006. A highway's road-effect zone for Desert Tortoises (Gopherus agassizii). Journal of Arid Environments 65:94-101.

Boarman, W.I, Patten, M.A., Camp, R.J., And Collis, S.J. 2006. Ecology of a population of subsidized predators: Common Ravens in the central Mojave Desert, California. Journal of Arid Environments 67:248-261.

Bour,R. ANDDuboIs,A.1984.Xerobates agassizii, 1857, synonyme ancient de Scaptochelys Bramble, 1982 (Reptilia, Chelonii, Testudinidae). Bulletin Mensuel de la Société Linnéenne de Lyon 53:30-32.
BOYER,T.H. AND BOYER,D.M.2006. Turtles, tortoises, and terrapins. In: Mader, D.R. (Ed.). Reptile Medicine and Surgery, 2nd Ed. Saunders Elsevier Inc., USA, pp. 78-99.

BRAMBLE, D.M.1982.Scaptochelys: generic revision and evolution of Gopher Tortoises. Copeia 1982:852-867.

Bramble, D.M. and Hutchinson, J.H.2014. Morphology, taxonomy, and distribution of North American tortoises. An evolutionary perspective.In: Rostal,D.C., McCoy,E.D., and Mushinsky, H.R. (Eds.). Biology and Conservation of North American Tortoises. Baltimore, MD: Johns Hopkins University Press, pp. 1-12.

Brand, L.A., Farnsworth, M.L., Meyers, J., Dickson, B.G., Grouios, C., Scheib, A.F., AND Scherer, R.D. 2016. Mitigationdriven translocation effects on temperature, condition, growth, and mortality of Mojave Desert Tortoise (Gopherus agassizii) in the face of solar energy development. Biological Conservation 200:104-111.

Brattstrom, B.H. 1961. Some new fossil tortoises from Western North America with remarks on zoogeography and paleoecology of tortoises. Journal of Paleontology 35:543-560.

BratTstrom, B.H.1965. Body temperatures of reptiles. American Midland Naturalist 73:376-422.

Brooks, M.L. 1995. Benefits of protective fencing to plant and rodent communities of the western Mojave Desert, California. Environmental Management 19:65-74.

Brooks, M.L. 1999. Alien annual grasses and fire in the Mojave Desert. Madroño 46:13-19.

BRooks, M.L. 2000. Competition between alien annual grasses and native annual plants in the Mojave Desert. American Midland Naturalist 144:92-108.

BRooKs, M.L. 2003. Effects of increased soil nitrogen on the dominance of alien annual plants in the Mojave Desert. Journal of Applied Ecology 40:344-353.

BRoOKS, M.L. 2009. Spatial and temporal distribution of non-native plants in upland areas of the Mojave Desert. In: Webb, R.H., Fenstermaker, L.F., Heaton, J.S., Hughson, D.L., McDonald, E.V., and Miller, D.M. (Eds.). The Mojave Desert. Ecosystem Processes and Sustainability. Reno, NV: University of Nevada Press, pp. 101-124.

BROOKS,M.L. AND BERRY,K.H.2006.Dominance and environmental correlates of alien annual plants in the Mojave Desert, USA. Journal of Arid Environments 67:100-124.

Brooks, M.L. AND Chambers, J.C. 2011. Resistance to invasion and resilience to fire in desert shrublands of North America. Rangeland Ecology and Management 64:431-438.

BRooKs, M.L. ANd EsQue, T.C. 2002. Alien plants and fire in Desert Tortoise (Gopherus agassizii) habitat of the Mojave and Colorado deserts. Chelonian Conservation and Biology 4:330-340.

BROOKS, M.L. AND LAIR, B.M. 2009. Ecological effects of vehicular routes in a desert ecosystem. In: Webb, R.H., Fenstermaker, L.F., Heaton, J.S., Hughson, D.L., McDonald, E.V., and Miller, D.M. (Eds.). The Mojave Desert. Ecosystem Processes and Sustainability. Reno: University of Nevada Press, pp. 168-195.

Brooks, M.L. And Matchett, J.R. 2006. Spatial and temporal patterns of wildfires in the Mojave Desert, 1980-2004. Journal of Arid Environments 67 (Supplement):148-164.

Brooks, M.L., Matchett, J.R., AND Berry, K.H. 2006. Effects of livestock watering sites on alien and native plants in the Mojave Desert, USA. Journal of Arid Environments 67 (Supplement):125-147.

Brown, M.B.,Schumacher,I.M., Klein, P.A.,Harris, K., Correll, T., AND JACOBSON, E.R. 1994. Mycoplasma agassizii causes upper respiratory tract disease in the Desert Tortoise. Infection and Immunity 62:4580-4586. 
Brown, M.B., Berry, K.H., Schumacher, I.M., Nagy, K.A., Christopher, M.M., and KleIn, P.A. 1999. Seroepidemiology of upper respiratory tract disease in the Desert Tortoise in the western Mojave Desert of California. Journal of Wildlife Diseases 35:716-727.

Buhlmann, K.A., Akre, T.S.B., Iverson, J.B., Karapatakis, D., Mittermeier, R.A., Georges, A., Rhodin, A.G.J., van Dijk, P.P., AND GiBBons, J.W. 2009. A global analysis of tortoise and freshwater turtle distributions with identification of priority conservation areas. Chelonian Conservation and Biology 8:116-149.

Bulova,S .J. 1994.Pattern of burrow use by Desert Tortoises: gender differences and seasonal trends. Herpetological Monographs 7:133-143.

Bulova, S.J.2002. How temperature, humidity, and burrow selection affect evaporative water loss in the Desert Tortoise. Journal of Thermal Biology 27:175-189.

Burge, B.L. 1977a. Daily and seasonal behavior, and areas utilized by the Desert Tortoise Gopherus agassizi in southern Nevada. Desert Tortoise Council Symposium Proceedings 1977:59-94.

Burge, B.L. 1977b. Movements and behavior of the Desert Tortoise (Gopherus agassizii). M.S. Thesis, University of Nevada, Las Vegas.

BuRgE,B.L. 1978. Physical characteristics and patterns of utilization of cover sites used by Gopherus agassizi in southern Nevada. Desert Tortoise Council Symposium Proceedings 1978:80-111.

Burge, B.L. AND BRADLEY, W.G. 1976. Population density, structure and feeding habits of the Desert Tortoise, Gopherus agassizi, in a low desert study area in southern Nevada. Desert Tortoise Council Symposium Proceedings 1976:51-74.

Bury, R.B. AND LuCKenBaCh, R.A. 2002. Comparison of Desert Tortoise (Gopherus agassizii) populations in an unused and offroad vehicle area in the Mojave Desert. Chelonian Conservation and Biology 4:457-463.

Bury, R.B. AND MarLow, R.W. 1973. The Desert Tortoise: will it survive? National Parks and Conservation Magazine 47:9-12.

California Department of Fish and Game Code. 1939-1981. Legislative history and regulations, Sections 200-203.1, 206, 2078, 208-210, 5000-5002, 5060, 5061. Sacramento, CA: California Fish and Game Code.

California Department of Fish and Wildlife. 2016. State and federally listed Endangered and Threatened animals of California. Sacramento, CA: California Department of Fish and Wildlife. Biogeographic Data Branch, California Natural Diversity Database, https://www.wildlife.ca.gov/data/cnddb, accessed 28 Sep 2016.

CAmp, C.L. 1916. Notes on local distribution and habits of amphibians and reptiles of southeastern California in the vicinity of Turtle Mountains. University of California Publications in Zoology 12:503-544.

Camp, R.J., Knight, R.L, Knight, H.A.L., Sherman, M.W., And KaWASHIMA,J.Y.1993. Food habits of nesting Common Ravens in the eastern Mojave Desert. Southwestern Naturalist 38:163-165.

CAmpbell, T. 1983. Some natural history observations of Desert Tortoises and other species on and near the Desert Tortoise Natural Area, Kern County, California. Desert Tortoise Council Symposium Proceedings 1983:80-88.

Chaffee, M.A. AND Berry, K.H. 2006. Abundance and distribution of selected elements in soils, stream sediments, and selected forage plants from Desert Tortoise habitats in the Mojave and Colorado deserts, USA. Journal of Arid Environments 67:35-87.

Christopher, M.M. 1999. Physical and biochemical abnormalities associated with prolonged entrapment in a Desert Tortoise.
Journal of Wildlife Diseases 35:361-366.

Christopher, M.M., Berry, K.H., Wallis, I.R., NAGy, K.A., Henen, B.T., And Peterson, C.C. 1999. Reference intervals and physiologic alterations in hematologic and biochemical values of free-ranging Desert Tortoises in the Mojave Desert. Journal of Wildlife Diseases 35:212-238.

Christopher, M.M., Berry, K.H., Henen, B.T., and Nagy, K.A. 2003. Clinical disease and laboratory abnormalities in freeranging Desert Tortoises in California (1990-1995). Journal of Wildlife Diseases 39:35-56.

Cites [Convention on International Trade in Endangered Species of Wild Fauna And Flora]. 2017. Appendices I, II and III. Valid from 4 October 2017, https://www.cites.org/eng/app/ appendices.php, accessed 31 July 2018.

Cooper, J.G. 1861. New Californian animals. Proceedings of the California Academy of Sciences (ser. 1) 2:18-123.

Cope, E.D. 1875. Check-list of North American Batrachia and Reptilia. Bulletin of the U.S. National Museum 1:1-104.

Curtin, A.J., Zug, G.R., And Spotila, J.R. 2009. Longevity and growth strategies of the Desert Tortoise (Gopherus agassizii) in twoAmerican deserts. Journal of Arid Environments 73:463-471.

Cypher, B.L., Kelly,E.C., Westall, T.L., and Van Horn Job, C.L. 2018. Coyote diet patterns in the Mojave Desert: implications for threatened Desert Tortoises. Pacific Conservation Biology 24:44-54.

D’Antonio, C.M. And Vitousek, P.M. 1992. Biological invasions by exotic grasses, the grass/fire cycle, and global change.Annual Reviews in Ecology and Systematics 23:63-87.

Davy, C.M., Edwards, T., Lathrop, A., Bratton, M., Hagan, M., Henen, B., Nagy, K.A., Stone, J., Hillard, L.S., and Murphy, R.W. 2011. Polyandry and multiple paternities in the threatened Agassiz's Desert Tortoise, Gopherus agassizii. Conservation Genetics 12:1313-1322.

Dickinson, V.M., Duck, T., Schwalbe, C.R., Jarchow, J.L., AND TRUeBLOOD, M.H.2001. Nasal and cloacal bacteria in free-ranging Desert Tortoises from the western United States. Journal of Wildlife Diseases 37:252-257.

Donoghue, S. 2006. Nutrition. In: Mader, D.R. (Ed.). Reptile Medicine and Surgery. Saunders Elsevier,Inc.,USA,pp. 251-298.

Drake, K.K., Medica, P.A., Esque, T.C., And Nussear, K.E. 2012. Gopherusagassizii (Agassiz's Desert Tortoise). Scute dysecdysis/ scute sloughing. Herpetological Review 43:473-474.

Drake, K.K., Esque, T.C., Nussear, K.E., DeFalco, L.A., ScolesSciulla, S.J., Modlin, A.T., And Medica, P.A. 2015. Desert Tortoise use of burned habitat in the eastern Mojave Desert. Journal of Wildlife Management 79:618-629.

Drake, K.K., Bowen, L, Nussear, K.E., Esque, T.C., Berger, A.J., Custer, N.A., Waters, S.C., Johnson, J.D., Miles, A.K., And LEWISON, R.L. 2016. Negative impacts of invasive plants on conservation of sensitive desert wildlife.Ecosphere 7(10):e01531.

Drake,K.K., Bowen,L.,Lewison, R.L.,Esque,T.C., Nussear, K.E., Braun, J., Waters, S.C., and Miles, A.K. 2017. Coupling genebased and classic veterinary diagnostics improves interpretation of health and immune function in the Agassiz's Desert Tortoise (Gopherus agassizii). Conservation Physiology 5:1-17.

DudA, J.J., KRZYSIK, A.J., AND FrEILICH,J.E. 1999. Effects of drought on Desert Tortoise movement and activity. Journal of Wildlife Management 63:1181-1192.

EDWARDS,T. AND BERRY, K.H.2013. Are captive tortoises a reservoir for conservation? An assessment of genealogical affiliation of captive Gopherus agassizii to local, wild populations. Conservation Genetics 14:649-659.

Edwards, T., Jarchow, C.J., Jones, C.A., AND Bonine, K.E. 2010. 
Tracing genetic lineages of captive Desert Tortoises in Arizona. Journal of Wildlife Management 74:801-807.

Edwards, T., Berry, K.H., Inman, R.D., Esque, T.C., Nussear, K.E., Jones, C.A., And Culver, M. 2015. Testing taxon tenacity of tortoises: evidence for a geographic selection gradient at a secondary contact zone. Ecology and Evolution 5:2095-2114.

Edwards, T., Karl, A.E., Vaughn, M., Rosen, P.C., Melendez Torres, C., And Murphy, R.W. 2016a. The Desert Tortoise trichotomy: Mexico hosts a third, new sister-species of tortoise in the Gopherus morafkai-G. agassizii group. ZooKeys 562:131-158.

Edwards, T., Tollis, M., Hsieh, P., Gutenkunst, R.N., Liu, Z., Kusumi, K., Culver, M., And Murphy, R.W. 2016b. Assessing models of speciation under different biogeographic scenario: an empirical study using multi-locus and RNA-seq analyses. Ecology and Evolution 6:379-396.

Edwards, T., Vaughn,M., Rosen,P.C.,MelendezTorres,C., Karl, A.E.,Culver,M., AND MurPhy,R.W.2016c. Shaping species with ephemeral boundaries: the distribution and genetic structure of the Desert Tortoise (Gopherus morafkai) in the Sonoran Desert region. Journal of Biogeography 43:484-497.

Egan, T.B., Parker, R.E., and Patrovsky, E.B. 2012. A view from the road: route designation in the western Mojave Desert. Designated Vehicle Network Field Review 2012. A report from Alliance for Responsible Recreation, $141 \mathrm{pp}$.

Emblidge, P.G., Nussear, K.E., Esque, T.C., Aiello, C.M., And WALDE,A.D.2015. Severe mortality of a population of threatened Agassiz's Desert Tortoises: the American Badger as a potential predator. Endangered Species Research 28:109-116.

EnNEn, J.R.,Lovich,J.E.,Meyer, K.P.,BJurlin, C.D., AND Arundel, T.R. 2012. Nesting ecology of a population of Gopherus agassizii at a utility-scale wind energy facility in southern California. Copeia 2012:222-228.

Esque, T.C., Schwalbe, C.R., DeFalco, L.A., Duncan, R.B., and HughES, T.J. 2003. Effects of desert wildfires on Desert Tortoise (Gopherus agassizii) and other small vertebrates. Southwestern Naturalist 48:103-111.

Esque, T.C., Nussear, K.E., Drake, K.K., Walde, A.D., Berry, K.H., Averill-Murray, R.C., Woodman, A.P., Boarman, W.I., Medica, P.A., Mack, J., and Heaton, J.S. 2010a. Effects of subsidized predators, resource variability, and human population density on Desert Tortoise populations in the Mojave Desert, USA. Endangered Species Research 12:167-177.

Esque, T.C., Young, J.A., AND Tracy,C.R. 2010b. Short-term effects of experimental fires on a Mojave Desert seed bank. Journal of Arid Environments 74:1302-1308.

FAGAN, W.F. AND Homes, E.E. 2006. Quantifying the extinction vortex. Ecology Letters 9:51-60.

Farnsworth,M.L.,Dickson,B.G.,Zachmann,L.J.,Hegeman,E.E., CAngelosi,A.R., JaCKsOn, T.G.,JR., AND ScheIB,A.F. 2015. Shortterm space-use patterns of translocated Mojave Desert Tortoise in Southern California. PLoS ONE 10, e0134250.

FARRELL, J. 1989. Some natural history observations of Raven behavior and predation on Desert Tortoise. Compilation of papers and abstracts from Symposia of the Desert Tortoise Council, 1987 through 1991:168.

Fedriani, J.M., Fuller, T.K., And Sauvajot, R.M. 2001. Does availability of anthropogenic food enhance densities of omnivorous mammals? An example. Coyotes in southern California. Ecography 24:325-331.

Field, K.J., Tracy, C.R., Medica, P.A., Marlow, R.W., and CoRN, P.S. 2007. Return to the wild: translocation as a tool in conservation of the Desert Tortoise (Gopherus agassizii).
Biological Conservation 136:232-245.

FLEISCHNER, T.L. 1994. Ecological costs of livestock grazing in western North America. Conservation Biology 8:629-644.

Forman, R.T.T., Sperling, D., Bissonette, J.A., Clevenger, A.P., Cutshall, C.D., Dale, V.H., Fahrig, L., France, R., Goldman, C.R., Heanue, K., Jones, J.A., Swanson, F.J., Turrentine, T., AND Winter, T.C. 2003. Road Ecology, Science and Solutions. Washington, DC: Island Press.

Foster, A.L., Berry, K, JACOBSON, E.R., AND Rytuba, J.J. 2009. American Geophysical Union, Fall Meeting 2009. Abstract B32B-04.

Franks, B.R., Avery, H.W., AND Spotila, J.R. 2011. Home range and movement of Desert Tortoises Gopherus agassizii in the Mojave Desert of California, USA.Endangered Species Research 13:191-201.

Freilich,J.E.,Burnham, K.P.,Collins, C.M., and Garry, C.A. 2000. Factors affecting population assessments of Desert Tortoises. Conservation Biology 14:1479-1489.

Garfin, G., Franco, G., Blanco, H., Comrie, A., Gonzalez, P., Piechota, T., Smyth, R., AND Waskom, R. 2014. Southwest. In: Melillo, J.M., Richmond, T.C., and Yohe, G.W. (Eds.). Climate Change Impacts in the United States: The Third National Climate Assessment.U.S.GlobalChange Research Program,pp.462-486, doi:10.7930/JO8G8HMN.

GERMANO,D.J.1993. Shell morphology of NorthAmerican tortoises. American Midland Naturalist 129:319-335.

Germano, J. And Perry, L. 2012. Natural history notes. Gopherus agassizii (Desert Tortoise). Cohabitation with American Badger. Herpetological Review 43:127.

Germano, J., Van Zerr, V.E., Esque, T.C., Nussear, K.E., and LAMBERSKI, N. 2014. Impacts of upper respiratory tract disease on olfactory behavior of the Mojave Desert Tortoise. Journal of Wildlife Diseases 50:354-358.

Gienger, C.M. AND Tracy, C.R. 2008. Ecological interactions between Gila Monsters (Heloderma suspectum) and Desert Tortoises (Gopherus agassizii). Southwestern Naturalist 53:265-268.

GILPIN, M.E. And SoulÉ, M.E. 1986. Minimum viable populations: processes of extinction. In: Soulé, M.E. (Ed.). Conservation Biology: The Science of Scarcity and Diversity. Sunderland, MA: Sinauer Associates, pp. 19-34.

Goodlett, G.O. AND GoodletT, G.C. 1992. Studies of unauthorized off-highway vehicle activity in the Rand Mountains and Fremont Valley, Kern County, California. Desert Tortoise Council Symposium Proceedings 1992:163-187.

Goolsby, D. 2016. Huge non-native tortoise found wandering Coachella Valley. The Desert Sun, 21 Oct 2016.

GRANDMAISON,D.D. AND FRARY,V.J.2012. Estimating the probability of illegal Desert Tortoise collection in the Sonoran Desert.Journal of Wildlife Management 76:262-268.

Grant, C. 1936. The southwestern Desert Tortoise, Gopherus agassizii. Zoologica 21:225-229.

Grover,M.C. And DeFALCO,L.A. 1995. Desert Tortoise (Gopherus agassizii): status of knowledge outline with references. U.S. Department of Agriculture, Forest Service, Intermountain Research Station, General Technical Report INT-GTR-316.

Hagerty, B.E. and Tracy, C.R. 2010. Defining population structure for the Mojave Desert Tortoise. Conservation Genetics 11:1795-1807.

Hagerty, B.E., Nussear, K.E., Esque, T.C., and Tracy, C.R. 2011. Making molehills out of mountains: landscape genetics of the Mojave Desert Tortoise. Landscape Ecology 26:267-280.

HARDY, R. 1976. The Utah population-a look in the 1970's. Desert 
Tortoise Council Symposium Proceedings 1976: 84-88.

Harless, M.L., Walde, A.D., Delaney, D.K., Pater, L.L., AND HaYes, W.K. 2009. Home range, spatial overlap, and burrow use of the Desert Tortoise in the west Mojave Desert. Copeia 2009:378-389.

Harless, M.L., Walde, A.D., Delaney, D.K., Pater, L.L., AND Hayes, W.K. 2010. Sampling considerations for improving home range estimates of Desert Tortoise: effects of estimator, sampling regime, and sex. Herpetological Conservation and Biology 5:374-387.

HaZARD, L.C., ShEMANSKi, D.R., AND NAGy, K.A. 2009. Nutritional quality of natural foods of juvenile Desert Tortoises (Gopherus agassizii): energy, nitrogen, and fiber digestibility. Journal of Herpetology 43:38-48.

HaZARD, L.C., Shemanski, D.R., And Nagy, K.A. 2010. Nutritional quality of natural foods of juvenile and adult Desert Tortoises (Gopherus agassizii): calcium, phosphorus, and magnesium digestibility. Journal of Herpetology 44:135-147.

Hazard, L.C., MorafKa, D.J., and Hillard, S. 2015. Postrelease dispersal and predation of head-started juvenile Desert Tortoises (Gopherus agassizii): effect of release site distance on homing behavior. Herpetological Conservation and Biology 10:504-515.

HenEn, B.T. 1997. Seasonal and annual energy budgets of female Desert Tortoises (Gopherus agassizii). Ecology 78:283-296.

Henen, B.T. 1999. Maternal behavior in Desert Tortoise (Gopherus agassizii) at Goffs, California. Desert Tortoise Council Symposium Proceedings 1999:25-27.

Henen,B.T.2002a.Energy and water balance, diet, and reproduction of female desert tortoises (Gopherus agassizii). Chelonian Conservation and Biology 4:319-329.

Henen, B.T. 2002b. Reproductive effort and reproductive nutrition of female Desert Tortoises: essential field methods. Integrative and Comparative Biology 42:43-50.

Henen, B.T. 2004. Capital and income breeding in two species of desert tortoise. Transactions of the Royal Society of South Africa 59:65-71.

HenEn, B.T. 2018. The 2017 tortoise translocation by the Marine Corps Air Ground Combat Center (Combat Center). Abstract, 43rd Symposium of the Desert Tortoise Council, 2018, http:// www.deserttortoise.org.

Henen, B.T., Peterson, C.C., WAllis, I.R., Berry, K.H., AND NAGy, K.A. 1998. Effects of climatic variation on field metabolism and water relations of Desert Tortoises. Oecologia 117:365-373.

Hessing,M.B. AND Johnson,C.D. 1982.Disturbance and revegetation of Sonoran Desert vegetation in an Arizona powerline corridor. Journal of Range Management 35:254-258.

Hinderle, D., Lewison, R.L., Walde, A.D., Deutschman, D., And BOARMAN, W.I. 2015. The effects of homing and movement behaviors on translocation: Desert Tortoises in the western Mojave Desert. Journal of Wildlife Management 79:137-147.

Homer, B.L., Berry, K.H., Brown, M.B., Ellis, G., AND J ACOBSON, E.R. 1998. Pathology of diseases in wild Desert Tortoises from California. Journal of Wildlife Diseases 34:508-523.

Hoover, F.G. 1995. An investigation of Desert Tortoise mortality in upland game guzzlers in the deserts of southern California. Desert Tortoise Council Symposium Proceedings 1996:36-43.

Hughson, D.L. 2009. Human population in the Mojave Desert: resources and sustainability. In: Webb, R.H., Fenstermaker, L.F., Heaton, J.S., Hughson, D.L., McDonald, E.V., and Miller, D.M. (Eds.). The Mojave Desert. Reno, NV: University of Nevada Press, pp. 57-77.

Hughson, D.L. AND DaRBY, N. 2013. Desert Tortoise road mortality in Mojave National Preserve, California. California Fish and Game 99:222-232.

HunTER, R. 1991. Bromus invasions on the Nevada Test Site: present status of $B$.rubens and B.tectorum with notes on their relationship to disturbance and altitude. Great Basin Naturalist 51:176-182.

Inman, R., Fotheringham, A.S., Franklin, J., Esque, T., Edwards, T., And Nussear, K. 2019. Local niche differences predict genotype associations in sister taxa of Desert Tortoise. Diversity and Distributions 00:1-16, doi:10.111/ddi.12927.

IUCN. 2019. Red List of Threatened Species. https://www. iucnredlist.org/.

IVERSON, J.B. 1992. A Revised Checklist with Distribution Maps of the Turtles of the World. Richmond, IN: Privately Printed, $363 \mathrm{pp}$.

JACOBSON, E.R. 1994. Causes of mortality and diseases in tortoises: a review. Journal of Zoo and Wildlife Medicine 25:2-17.

JACOBSON, E.R. AND BERRY, K.H. 2012. Mycoplasma testudineum in free-ranging Desert Tortoises, Gopherus agassizii. Journal of Wildlife Diseases 48:1063-1068.

JACOBSON,E.R.,GASKIN,J.M.,BROwn,M.B.,HARRIS,R.K.,GARDINER, C.H., LaPointe, J.L., Adams, H.P., and Reggiardo, C. 1991. Chronic upper respiratory tract disease of free-ranging Desert Tortoises (Xerobates agassizii). Journal of Wildlife Diseases 27:296-316.

JACOBSON,E.R., Wronski, T.J., SchumaChER, J., REgGiardo, C., AND BERRY,K.H. 1994. Cutaneous dyskeratosis in free-ranging Desert Tortoises, Gopherus agassizii, in the Colorado Desert of southern California. Journal of Zoo and Wildlife Medicine 25:68-81.

JaCOBSON,E.R.,BERry,K.H.,StACy,B.,HuZELLA,L.M.,KaLASINSKY, V.F., Fleetwood, M.L., and Mense, M.G. 2009. Oxalosis in wild Desert Tortoises, Gopherus agassizii. Journal of Wildlife Diseases 45:982-988.

Jacobson, E.R., Berry, K.H., Wellehan, J.F.X., JR., Origgi, F., Childress, A.L., Braun, J., Schrenzel, M., Yee, J., And Rideout, B. 2012. Serologic and molecular evidence for testudinid herpesvirus 2 infection in wild Agassiz's Desert Tortoises, Gopherus agassizii. Journal of Wildlife Diseases 48:747-757.

JaCOBSON, E.R., HeArd, D., AND BerRy, K.H. 2013. Necropsies of a Russian Tortoise (Testudo horsfieldii) and Agassiz's Desert Tortoise (Gopherus agassizii) from California. Report to the U.S. Geological Survey, Riverside, California.

JaCOBSON,E.R.,BRown,M.B.,WendLAND,L.D.,Brown,D.R.,KLEIN, P.A., Christopher, M.M., AND BerRy, K.H.2014. Mycoplasmosis and upper respiratory tract disease of tortoises: a review and update. Veterinary Journal 201:257-264.

JAEGER,E.C. 1922. Denizens of the Desert. Boston, MA: Houghton Mifflin Co.

JAEGER, E.C. 1950. Our Desert Neighbors. Stanford, CA: Stanford University Press.

JAMES, G.W. 1906. The Wonders of the Colorado Desert. Vol. I. Boston, MA: Little Brown and Co.

Jennings, W.B. And Berry, K.H. 2015. Desert Tortoises (Gopherus agassizii) are selective herbivores that track the flowering phenology of their preferred food plants. PLoS ONE 10(1):e0116716.

Jepson Flora Project (eds.) 2018. Jepson eFlora, 6th Revision. http://ucjeps.berkeley.edu/eflora/, accessed 9 November 2018.

Johnson, H.B., VASEK, F.C., AND YonKers, T. 1975. Productivity, diversity and stability relationships in Mojave Desert roadside vegetation. Bulletin of the Torrey Botanical Club 102:106-115.

Johnson, A.J., Morafka, D.J, and Jacobson, E.R. 2006. Seroprevalence of Mycoplasma agassizii and tortoise herpesvirus in captive Desert Tortoises (Gopherus agassizii) from the Greater Barstow Area, Mojave Desert, California. Journal of 
Arid Environments 67:192-201.

Johnston,F.J.1987.The Bradshaw Trail.Revised edition.Riverside, CA: Historical Commission Press.

Keith, K., Berry, K.H., and Weigand, J. 2008. When Desert Tortoises are rare: testing a new protocol for assessing status. California Fish and Game 94:75-97.

Kelly, E.C., Cypher, B.L., And Germano, D.J. 2019. Temporal variation in foraging patterns of Desert KitFoxes (Vulpes macrotis arsipus) in the Mojave Desert, California, USA. Journal of Arid Environments 167:1-7.

Kemp, P.R. AND BRooKs, M.L. 1998. Exotic species of California deserts. Fremontia 26:30-34.

Kim, C.S., Stack, D.H., AND Rytuba, J.J. 2012. Fluvial transport and surface enrichment of arsenic in semi-arid mining regions: examples from the Mojave Desert, California. Journal of Environmental Monitoring 14:1798-1813.

Kim, C.S., Anthony, T.L., Goldstein, D., and Rytuba, J.J. 2014. Windborne transport and surface enrichment of arsenic in semi-arid mining regions: examples from the Mojave Desert, California. Aeolian Research 14:85-96.

KNIGHT, R.L. AND KaWASHIMA, J.Y. 1993. Responses of Raven and Red-tailed Hawk populations to linear right-of-ways. Journal of Wildlife Management 57:266-271.

Knight, R.L., Knight, H.A.L., And CAmp, R.J. 1993. Raven populations and land-use patterns in the Mojave Desert, California. Wildlife Society Bulletin 21:469-471.

Knight, R.L., CAmp, R.J., AND KNIGHT, H.A.L. 1998. Ravens, Cowbirds, and Starlings at springs and stock tanks, Mojave National Preserve, California. Great Basin Naturalist 58:393-395.

Knight, R.L., CAmp, R.J., Boarman, W.I., and Knight, H.A.L. 1999. Predatory bird populations in the east Mojave Desert, California. Great Basin Naturalist 59:331-338.

Kristan, W.B., III And Boarman, W.I. 2003. Spatial pattern of risk of Common Raven predation on Desert Tortoises. Ecology 84:2432-2443.

KRISTAN,W.B.,III AND BOARMAN, W.I.2007.Effects of anthropogenic developments on Common Raven nesting biology in the west Mojave Desert. Ecological Applications 17:1703-1713.

Kristan, W.B., III, BoArman, W.I., AND Crayon, J.J. 2004. Diet composition of Common Ravens across the urban-wildland interface of the west Mojave Desert. Wildlife Society Bulletin 32:244-253.

KRZYSIK, A.J. 2002. A landscape sampling protocol for estimating distribution and density patterns of Desert Tortoises at multiple spatial scales. Chelonian Conservation and Biology 4:366-379.

Lamb, T., Avise, J.C., And GibBons, J.W. 1989. Phylogeographic patterns in mitochondrialDNA of the Desert Tortoise (Xerobates agassizii), and evolutionary relationships among the North American Gopher Tortoises. Evolution 43:76-87.

Lance, V.A. And Rostal, D.C. 2002. The annual reproductive cycle of the male and female Desert Tortoise: physiology and endocrinology. Chelonian Conservation and Biology 4:302-312.

Latch, E.K., Boarman, W.I., Walde, A., AND Fleischer, R.C. 2011. Fine-scale analysis reveals cryptic landscape genetic structure in Desert Tortoises. PLoS ONE 6:e27794, doi:10.1371/journal. pone.0027794.

Lathrop, E.W. and Archbold, E.F. 1980a. Plant response to Los Angeles aqueduct construction in the Mojave Desert. Environmental Management 4:137-148.

LATHROP, E.W. AND ARCHBOLD, E.F. 1980b. Plant response to utility right of way construction in the Mojave Desert. Environmental Management 4:215-226.

LEI, S.A. 2009. Rates of soil compaction by multiple land use practices in southern Nevada. In: Webb, R.H., Fenstermaker, L.F., Heaton, J.S., Hughson, D.L., McDonald, E.V., and Miller, D.M. (Eds.). The Mojave Desert. Ecosystem Processes and Sustainability. Reno: University of Nevada Press, pp. 159-167. LEU, M., HANSER, S.E., AND KNICK, S.T. 2008. The human footprint in the West: a large-scale analysis of anthropogenic impacts. Ecological Applications 18:1119-1139.

LONGSHORE, K.M., JAEGER, J.R., AND S APPINGTON, J.M. 2003. Desert Tortoise (Gopherus agassizii) survival at two eastern Mojave Desert sites: death by short-term drought? Journal of Herpetology 37:169-177.

Loughran, C.L., EnNEn, J.R., AND Lovich, J.E. 2011. Gopherus agassizii (Desert Tortoise). Burrow Collapse. Herpetological Review 42:593.

Lovich, J.E.2011. Natural history notes. Gopherusagassizii (Desert Tortoise) and Crotalus ruber (Red Diamond Rattlesnake). Burrow co-occupancy. Herpetological Review 42:421.

Lovich, J.E. AND DANIELs, R. 2000. Environmental characteristics of Desert Tortoise (Gopherus agassizii) burrow locations in an altered industrial landscape. Chelonian Conservation and Biology 3:714-721.

Lovich, J.E., Ennen, J.R., Madrak, S., Meyer, K., Loughran, C., Buurlin, C., Arundel, T.R., Turner, W., Jones, C., And GroenendaAL, G.M. 2011a. Effects of wind energy production on growth, demography, and survivorship of a Desert Tortoise (Gopherus agassizii) population in southern California with comparisons to natural populations. Herpetological Conservation and Biology 6:161-174.

Lovich, J.E., Ennen, J.R., Madrak, S., and Grover, B. 2011 b. Turtles, culverts, and alternative energy development: an unreported but potentially significant mortality threat to the Desert Tortoise (Gopherus agassizii). Chelonian Conservation and Biology 10:124-129.

Lovich, J.E., Ennen, J.R., MadraK, S.V., Loughran, C.L., Meyer, K.P., ARundel, T.R., AND BJuRLin, C.D. 2011c. Long-term postfire effects on spatial ecology and reproductive output of female Agassiz's desert tortoises (Gopherus agassizii) at a wind energy facility near Palm Springs, California, USA. Fire Ecology 7: doi:10.4996/fireecology.0703075.

Lovich, J.E., Agha, M., Meulblok, M., Meyer, K., Ennen, J.R., Loughran, C., MadraK, S., and Buurlin, C. 2012. Climatic variation affects clutch phenology in Agassiz's Desert Tortoise Gopherus agassizii. Endangered Species Research 19:63-74.

Lovich, J.E., Agha, M., Yackulic, C.B., Meyer-Wilkins, K., Butrlin, C., Ennen, J.R., Arundel, T.R., And Austin, M. 2014a. Nest site characteristics, nesting movements, and lack of longterm nest site fidelity in Agassiz's Desert Tortoises at a wind energy facility in southern California. California Fish and Game 100:404-416.

Lovich, J.E., Yackulic, C.B., Freilich, J.E., Agha, M., Austin, M., Meyer, K.P., Arundel, T.R., Hansen, J., Vamstad, M.S., AND Root, S.A. 2014b. Climatic variation and tortoise survival: has a desert species met its match? Biological Conservation 169:214-224.

Lovich, J.E., Ennen, J.R., Yackulic, C.B., Meyer-Wilkins, K., Agha, M., Loughran, C., Buurlin, C., Austin, M., And MadraK, S. 2015. Not putting all their eggs in one basket: bet-hedging despite extraordinary annual reproductive output of Desert Tortoises. Biological Journal of the Linnean Society 115:399-410.

Lovich, J.E.,Agha, M., EnNen, J.R.,Arundel, T.R., ANd Austin, M. 2018a. Agassiz's Desert Tortoise (Gopherus agassizii) activity areas are little changed after wind turbine-induced fires in California. International Journal of Wildland Fire 27:851-856. 
Lovich, J.E., Puffer, S.R.,Agha, M., Ennen, J.R., MeYer-Wilkins, K., Tennant, L.A., Smith, A.L., Arundel, T.R., Brundige, K.D., AND Vamstad, M.S. 2018b. Reproductive output and clutch phenology of female Agassiz's Desert Tortoises (Gopherus agassizii) in the Sonoran Desert region of Joshua Tree National Park. Current Herpetology 37:40-57.

Mack, J.S., Berry, K.H., Miller, D.M, and Carlson, A.S. 2015. Factors affecting the thermal environment of Agassiz's Desert Tortoise (Gopherus agassizii) cover sites in the central Mojave Desert during periods of temperature extremes. Journal of Herpetology 49:405-414.

MAcK, J.S., SchneIder, H.E., AND Berry, K.H. 2018. Crowding affects health, growth, and behavior in headstart pens for Agassiz's Desert Tortoise. Chelonian Conservation and Biology 17:14-26.

Marlow, R.W. and Tollestrup, K. 1982. Mining and exploitation of natural mineral deposits by the Desert Tortoise, Gopherus agassizii. Animal Behaviour 30:475-478.

Marushia, R.G., Brooks, M.L., And Holt, J.S. 2012. Phenology, growth, and fecundity as determinants of distribution in closely related nonnative taxa. Invasive Plant Science and Management 5:217-229.

McGinnis, S.M. And Voigt, W.G. 1971. Thermoregulation in the Desert Tortoise, Gopherus agassizii. Comparative Biochemistry and Physiology A 40:119-126.

McLUCKIE, A.M. AND FridelL, R.A. 2002. Reproduction in a Desert Tortoise (Gopherus agassizii) population on the Beaver Dam Slope, Washington County, Utah. Chelonian Conservation and Biology 4:288-294.

McLuckie, A.M., Harstad, D.L., Marr, J.W., and Fridell, R.A. 2002. Regional Desert Tortoise monitoring in the Upper Virgin River Recovery Unit, Washington County, Utah. Chelonian Conservation and Biology 4:380-386.

Medica, P.A. AND ECKERT, S.E. 2007. Gopherus agassizii (Desert Tortoise). Food/mechanical injury. Herpetological Review 38: 445-447.

Medica, P.A. and Greger, P.D. 2009. Gopherus agassizii (Desert Tortoise). Predation by Mountain Lion. Herpetological Review 40:75-77.

Medica,P.A.,Bury, R.B., ANd Luckenbach, R.A. 1980.Drinking and construction of watercatchments by the Desert Tortoise, Gopherus agassizii, in the Mojave Desert. Herpetologica 36:301-304.

Medica,P.A.,Nussear, K.E.,Esque, T.C., ANd SAethre, M.B. 2012. Long-term growth of Desert Tortoises (Gopherus agassizii) in a southern Nevada population. Journal of Herpetology 46:213-220.

Mertens, R. AND Wermuth, H. 1955. Die rezenten Schildkröten, Krokodile und Brückenechsen. Eine kritische Liste der heute lebendenArten und Rassen.Zoologische Jahrbücher 83:323-440.

Miller, L. 1932. Notes on the Desert Tortoise (Testudo agassizii). Transactions of the San Diego Society of Natural History 10:399-402.

MilLER, R.D. 1938. Saga of the walking rock. Desert Magazine $1: 22-23$.

Minnich, R.A. 2008. California's Fading Wildflowers: Lost Legacy and Biological Invasions. University of California Press.

Minnich, R.A. And SAnders, A.C. 2000. Brassica tournefortii Gouan. In: Bossard, C.C., Randall, J.M., and Hoshovsky, M.C. (Eds.). Invasive Plants of California's Wildlands. Berkeley, CA: University of California Press, pp. 68-72.

MorafKa, D.J. AND Berry, K.H. 2002. Is Gopherus agassizii a desert-adapted tortoise, or an exaptive opportunist? Implications for tortoise conservation. Chelonian Conservation and Biology 4:263-287.

Morafka, D.J., Berry, K.H, and Spangenberg, E.K. 1997.
Predator-proof field enclosures for enhancing hatching success and survivorship of juvenile tortoises: a critical evaluation. In: Van Abbema, J. (Ed.). Proceedings: Conservation, Restoration, and Management of Tortoises and Turtles-An International Conference. New York, NY: New York Turtle and Tortoise Society and the WCS Turtle Recovery Program, pp. 147-165.

Mueller, J.M., Sharp, K.R., Zander, K.K., Rakestraw, D.L., Rautenstrauch, K.R., AND Lederle, P.E. 1998. Size-specific fecundity of the Desert Tortoise (Gopherus agassizii). Journal of Herpetology 32:313-319.

Mulder,K.P.,Walde,A.D.,Boarman, W.I.,Woodman,A.P.,Latch, E.K., AND FLEISCHER, R.C.2017. No paternal genetic integration in Desert Tortoises (Gopherus agassizii) following translocationinto an existing population. Biological Conservation 210:318-324.

Munson, S.M., Long, A.L., Wallace, C.S.A., And Webb, R.H. 2016. Cumulative drought and land-use impacts on perennial vegetation across a North American dryland region. Applied Vegetation Science 19:430-441.

Murphy, R.W. 2014. Systematics of extant North American tortoises. In: Rostal, D.C., McCoy, E.D., and Mushinsky, H.R. (Eds.). Biology and Conservation of North American Tortoises. Baltimore, MD: Johns Hopkins University Press, pp. 25-29.

Murphy, R.W., Berry, K.H., Edwards, T., And McLuckie, A.M. 2007. A genetic assessment of the recovery units for the Mojave population of the Desert Tortoise, Gopherus agassizii. Chelonian Conservation and Biology 6:229-251.

Murphy, R.W., Berry, K.H., Edwards, T., Leviton, A.E., Lathrop, A., AND Riedle, J.D. 2011. The dazed and confused identity of Agassiz's land tortoise, Gopherus agassizii (Testudines, Testudinidae) with the description of a new species, and its consequences for conservation. ZooKeys 113:39-71.

Nafus, M.G., Tuberville, T.D., Buhlmann, K.A., and Todd, B.D. 2013. Relative abundance and demographic structure of Agassiz's Desert Tortoise (Gopherus agassizii) along roads of varying size and traffic volume. Biological Conservation 162:100-106.

Nafus, M.G., Esque, T.C., Averill-Murray, R.C., Nussear, K.E., AND SwaISGOOD, R.R. 2016. Habitat drives dispersal and survival of translocated juvenile Desert Tortoises. Journal of Applied Ecology 54:430-438. doi: 10.1111/1365-2664.12774.

Nagy, K.A. And Medica, P.A. 1986. Physiological ecology of Desert Tortoises in southern Nevada. Herpetologica 42:73-92.

NAGY, K.A., Henen, B.T., AND Vyas, D.B. 1998. Nutritional quality of native and introduced food plants of wild Desert Tortoises. Journal of Herpetology 32:260-267.

NaGy, K.A., Hillard, L.S., Dickson, S., AND MorafKa, D.J. 2015 a. Effects of artificial rain on survivorship, body condition and growth of head-started hatchlings, and on survivorship of headstarted Desert Tortoises (Gopherus agassizii) released to open desert. Herpetological Conservation and Biology 10:535-549.

Nagy, K.A., Hillard, L.S., Tuma, M.W., and MorafKa, D.J. 2015b. Head-started Desert Tortoises (Gopherus agassizii): movements, survivorship and mortality causes following their release. Herpetological Conservation and Biology 10:203-215.

Nagy, K.A., Kuchling, G., Hillard, L.S., and Henen B.T. 2016. Weather and sex ratios of head-started Agassiz's Desert Tortoise Gopherus agassizii juveniles hatched in natural habitat enclosures. Endangered Species Research 30:145-155.

Nelson, B. 2010. Huge 100-pound African tortoise found roaming Arizona desert. Mother Nature Network, 21 December 2010. https://www.mnn.com/.

NiCHOLSON,L. AND HumPHREYs, K. 1981. Sheep grazing at the Kramer study plot, San Bernardino County, California. Desert Tortoise Council Symposium Proceedings 1981:163-190. 
NorRIs,F. 1982. On beyond reason: homesteading in the California Desert, 1885-1940. Southern California Quarterly - Historical Society of Southern California 64:297-312.

Nussear, K.E., Esque, T.C., Haines, D.F., and Tracy, C.R. 2007. Desert Tortoise hibernation: temperatures, timing, and environment. Copeia 2007:378-386.

Nussear, K.E., Esque, T.C., Inman, R.D., Gass, L., Thomas, K.A., Wallace, C.S.A., Blainey, J.B., Miller, D.M., and WebB, R.H. 2009. Modeling habitat of the Desert Tortoise (Gopherus agassizii) in the Mojave and parts of the Sonoran deserts of California, Nevada, Utah, and Arizona. U.S. Geological Survey, Open-File Report 2009-1102.

Nussear, K.E., Tracy, C.R., Medica, P.A., Wilson, D.S., Marlow, R.W., AND CORN, P.S. 2012. Translocation as a conservation tool for Agassiz's Desert Tortoises: survivorship, reproduction, and movements. Journal of Wildlife Management 767:1341-1353.

O'Connor, M.P., Zimmerman, L.C., Ruby, D.E., Bulova, S.J., AND Spotila, J.R. 1994. Home range size and movements by Desert Tortoises, Gopherus agassizii, in the eastern Mojave Desert. Herpetological Monographs 8:60-71.

OftedAL, O.T. 2002. Nutritional ecology of the Desert Tortoise in the Mojave and Sonoran deserts. In: Van Devender, T.R. (Ed.). The Sonoran Desert Tortoise: Natural History, Biology and Conservation. Tucson, AZ: The University of Arizona Press and the Arizona-Sonora Desert Museum, pp. 194-241.

Oftedal, O.T., Hillard, S., AND MorafKa, D.J. 2002. Selective spring foraging by juvenile Desert Tortoises (Gopherus agassizii) in the Mojave Desert: evidence of an adaptive nutritional strategy. Chelonian Conservation and Biology 4:341-352.

Ottley, J.R. And Velázques Solis, V.M. 1989. An extant, indigenous tortoise population in Baja California Sur, Mexico, with the description of a new species of Xerobates (Testudines: Testudinidae). Great Basin Naturalist 49:496-502.

Palmer, K.S., Rostal, D.C., Grumbles, J.S., and Mulvey, M. 1998. Long-term sperm storage in the Desert Tortoise (Gopherus agassizii). Copeia 1998:702-705.

Peterson, C.C. 1994. Different rates and causes of high mortality in two populations of the threatened Desert Tortoise Gopherus agassizii. Biological Conservation 70:101-108.

Peterson, C.C. 1996. Anhomeostasis: seasonal water and solute relations in two populations of the Desert Tortoise (Gopherus agassizii) during chronic drought. Physiological Zoology 69:1324-1358.

PIECHOWsKi, C. 2015. Analysis and results of off-road vehicle use violation monitoring and law enforcement actions in the West Mojave Planning Area of the California Desert Conservation Area by the Bureau of Land Management. Report from Defenders of Wildlife, California Program Office, Sacramento, California.

Prose, D.V. 1985.Persisting effects of armored military maneuvers on some soils of the Mojave Desert. Environmental Geology and Water Sciences 7:163-170.

Prose, D.V. 1986. Map of areas showing visible land disturbances caused by two military training exercises in the Mojave Desert, California. Reston, VA: U.S. Geological Survey Miscellaneous Field Studies, Map MF-1855.

Prose, D.V. And WilshiRe, H.G. 2000. The lasting effects of tank maneuvers on desert soils and intershrub flora. U.S. Geological Survey, Open-File Reprt OF 00-512.

Prose, D.V., Metzger, S.K., And Wilshire, H.G. 1987. Effects of substrate disturbance on secondary plant succession: Mojave Desert, California. Journal of Applied Ecology 24:305-313.

Ragsdale, S. 1939. My friend, the tortoise. Desert Magazine $2: 21-22$
RAO,L.E. AND ALLEN,E.B. 2010. Combined effects of precipitation and nitrogen deposition on native and invasive winter annual production in California deserts. Oecologia 162:1035-1046.

Rao, L.E., Steers, R.J., And Allen, E.B. 2011. Effects of natural and anthropogenic gradients on native and exotic winter annuals in a southern California desert. Plant Ecology 212:1079-1089.

Rautenstrauch, K.R. And O'FarRell, T.P. 1998. Abundance of Desert Tortoises on the Nevada Test Site. Southwestern Naturalist 43:407-411.

Rautenstrauch, K.R., Rakestraw, D.L, Brown, G.A., Boone, J.L., AND LEDERLE, P.E. 2002. Patterns of burrow use by Desert Tortoises (Gopherusagassizii) in southcentral Nevada. Chelonian Conservation and Biology 4:398-405.

Rhodin, A.G.J., Stanford, C.B., van Dijk, P.P., Eisemberg, C., Luiselli, L., Mittermeier, R.A., Hudson, R., Horne, B.D., Goode, E.V., Kuchling, G., Walde, A., BaArd, E.H.W., Berry, K.H., Bertolero, A., Blanck, T.E.G., Bour, R., Buhlmann, K.A., Cayot, L.J., Collett, S., Currylow, A., Das, I., Diagne, T., Ennen, J.R., Forero-Medina, G., Frankel, M.G., Fritz, U., García, G., Gibbons, J.W., Gibbons, P.M., Gong, S., Guntoro, J., Hofmeyr, M.D., Iverson, J.B., Kiester, A.R., Lau, M., Lawson, D.P., Lovich, J.E., Moll, E.O., Páez, V.P., PalomoRamos, R., Platt, K., Platt, S.G., Pritchard, P.C.H., Quinn, H.R., RAHMAN, S.C., RANDRIANJAFIZANAKA, S.T., SCHAFFER, J., Selman, W., Shaffer, H.B., Sharma, D.S.K., Shi, H., Singh, S., Spencer, R., Stannard, K., Sutcliffe, S., Thomson, S., AND Vogt, R.C. 2018. Global conservation status of turtles and tortoises (Order Testudines). Chelonian Conservation and Biology 17:135-161.

Rico, Y., Edwards, T., Berry, K.H., Karl, A.E., Henen, B.T., and MurPHY, R.W. 2015. Re-evaluating the spatial genetic structure of Agassiz's Desert Tortoise using landscape genetic simulations. Abstract. 40th Symposium of the Desert Tortoise Council, 2015, http://www.deserttortoise.org.

Roberson, J.B., Burge, B.L., And Hayden, P. 1985. Nesting observations of free-living Desert Tortoises (Gopherus agassizii) and hatching success of eggs protected from predators. Desert Tortoise Council Symposium Proceedings 1985:91-99.

Rostal, D.C., Lance, V.A., Grumbles, J.S., and Alberts, A.C. 1994. Seasonal reproductive cycle of the Desert Tortoise (Gopherus agassizii) in the eastern Mojave Desert.Herpetological Monographs 8:72-82.

Rostal, D.C., Wibbels, T., Grumbles, J.S., Lance, V.A., and Spotila, J.R. 2002. Chronology of sex determination in the Desert Tortoise. Chelonian Conservation and Biology 2002:313-318.

Rowlands, P.G., Johnson, H., Ritter, E., And Endo, A. 1982. The Mojave Desert. In: Bender, G.L. (Ed.). Reference Handbook on the Deserts of North America. Westport, CT: Greenwood Press, pp. 103-162.

Sánchez-Ramírez, S., Rico, Y., Berry, K.H, Edwards, T., Karl, A.E., Henen, B.T., And Murphy, R.W. 2018. Landscape limits gene flow and drives population structure in Agassiz's Desert Tortoise (Gopherus agassizii). Scientific Reports, https://www. nature.com/articles/s41598-018-29395-6.

Sarhadi,A.,Ausín, M.C., WiPer, M.P., Touma,D., And Diffenbaugh, N.S. 2018. Multidimensional risk in a nonstationary climate: joint probability of increasingly severe warm and dry conditions. Science Advances 4:eaau3487.

SchneIder, J.S. And Everson, G.D. 1989. The Desert Tortoise (Xerobates agassizii) in the prehistory of the southwestern Great Basin and adjacent areas. Journal of California and Great Basin Anthropology 11:175-202.

SCHNEIDER,H.E. AND ALLEN, E.B.2012. Effects of elevated nitrogen 
and exotic plant invasion on soil seed bank composition in Joshua Tree National Park. Plant Ecology 213:1277-1287.

Seager, R., Ting, M., Held, I., Kushnir, Y., Lu, J., Vecchi, G., Huang, H., Harnik, N., LeetmaA, A., Lau, N., Li, C., Velez, J., AND NAIK, N. 2007. Model projections of an imminent transition to a more arid climate in southwestern North America. Science, New Series 316:1181-1184.

SElzer, M.D. AND Berry, K.H. 2005. Laser ablation ICP-MS profiling and semiquantitative determination of trace element concentrations in Desert Tortoise shells: documenting the uptake of elemental toxicants. Science of the Total Environment 339:253-265.

Sieg,A.E., Gambone, M.M., Wallace, B.P.,Clusella-Trullas, S., Spotila, J.R., AND Avery, H.W. 2015. Mojave Desert Tortoise (Gopherus agassizii) thermal ecology and reproductive success along a rainfall cline. Integrative Zoology 10:282-294.

Smith, S.D., Huxman, T.E., Zitzer, S.F., Charlet, T.N., Housman, D.C., Coleman, J.S., Fenstermaker, L.K., Seemann, J.R., and NowAK, R.S. 2000. Elevated $\mathrm{CO}_{2}$ increases productivity and invasive species success in an arid ecosystem. Nature 408:79-82.

SPEARS, J.R. 1892. Illustrated Sketches of Death Valley and other Borax Deserts of the Pacific Coast. Chicago and New York: Rand, McNally \& Co. [Reprint 1977. San Fernando, CA: Sagebrush Press.]

Stebbins, R.C. 1966. A Field Guide to Reptiles and Amphibians in the Western United States. Boston: Houghton-Mifflin Co.

SPENCELEY,A.,MACK, J., AND BERRY, K.H.2015. Gopherus agassizii (Agassiz's Desert Tortoise).Attempted predation.Herpetological Review 46:422-423.

Steiger, N.J., Smerdon, J.E., Cook, B.I., Seager, R., Williams, A.P., AND CoOK, E.R. 2019. Oceanic and radiative forcing of medieval megadroughts in the American Southwest. Science Advances 5:eax0087.

STEJNEGER, L. 1893. Annotated list of the reptiles and batrachians collected by the Death Valley Expedition in 1891, with descriptions of new species. North American Fauna 7:159-228.

Stephens, F. 1914. Arid California and its animal life. Biennial Report of the California Fish and Game Commission 23:127-135.

Stone, K.J. 1989. Foxsong. 100 Years of Cow Ranching in the San Bernardino Mountains/Mojave Desert. Memorial Edition. Morongo Valley, CA: Sagebrush Press.

Suazo, A.A., Spencer, J.E., Engel, E.C., And Abella, S.R. 2012. Responses of native and non-native Mojave Desert winter annuals to soil disturbance and water additions. Biological Invasions 14:215-227.

SyphaRd,A.D., KeEley,J.E., ANd Abatzoglou, J.T.2017.Trends and drivers of fire activity vary across California aridland ecosystems. Journal of Arid Environments 144:110-122.

Todd, B.D., Halstead, B.J., Chiquoine, L.P., Peaden, J.M., Buhlmann, K.A., Tuberville, T.D., and Nafus, M.G. 2016. Habitat selection by juvenile Mojave Desert Tortoises. Journal of Wildlife Management 80:720-728.

Tollis, M.,DeNardo, D.F.,Cornelius, J.A.,Dolby,G.A.,Edwards, T.,Henen,B.T., Karl,A.E., Murphy, R.W., and Kusumi, K.2017. The Agassiz's Desert Tortoise genome provides a resource for the conservation of a threatened species. PLoS ONE 12(5): $\mathrm{e} 0177708$.

Trader, M.R., Brooks, M.L., and Draper, J.V. 2006. Seed production by the non-native Brassica tournefortii (Sahara mustard) along desert roadsides. Madroño 53:313-320.

TTWG [Turtle Taxonomy Working Group: Rhodin, A.G.J., Iverson, J.B., Bour, R., Fritz, U., Georges, A., Shaffer, H.B., AND van DiJK, P.P.]. 2017. Turtles of the World: Annotated Checklist and Atlas of Taxonomy, Synonymy, Distribution, and
Conservation Status (8th Ed.). Chelonian Research Monographs 7:1-292.

Tuma, M.W., Millington, C., Schumaker, N., and Burnett, P. 2016. Modeling Agassiz's Desert Tortoise population response to anthropogenic stressors. Journal of Wildlife Management 80:414-429.

Turner, F.B., Medica, P.A., And Lyons, C.L. 1984. Reproduction and survival of the Desert Tortoise (Scaptochelys agassizii) in Ivanpah Valley, California. Copeia 1984:811-820.

Turner, F.B., Hayden, P., Burge, B.L., And Roberson, J.B. 1986. Egg production by the Desert Tortoise (Gopherus agassizii) in California. Herpetologica 42:93-104.

Turner, F.B., Berry, K.H., Randall, D.C., and White, G.C. 1987. Population ecology of the Desert Tortoise at Goffs, California, 1983-1986. Report to the Southern California Edison Company, Research and Development Series 87-RD-81.

Turtle Conservation Coalition [Stanford, C.B., Rhodin, A.G.J., van Dijk, P.P., Horne, B.D., Blanck, T.B.D., Goode, E.V., Hudson, R., Mittermeier, R.A., Currylow, A., Eisemberg, C., Frankel, M., Georges, A., Gibbons, P.M., Juvik, J.O., KuChling, G., Luiselli, L., Shi, H., Singh, S., ANd W Alde W. (Eds).]. 2018. Turtles in Trouble: the World's 25+ Most Endangered Tortoises and Freshwater Turtles - 2018. Ojai, CA: IUCN SSC Tortoise and Freshwater Turtle Specialist Group, Turtle Conservancy, Turtle Survival Alliance, Turtle Conservation Fund, Chelonian Research Foundation, Conservation International, Wildlife Conservation Society, and Global Wildlife Conservation, 80 pp.

USBLM [U.S. Bureau of Land Management]. 1973. Interim Critical Management Plan for Recreational Vehicle Use in the California Desert. Sacramento, CA: Department of the Interior, Bureau of Land Management.

USBLM [U.S. Bureau of Land Management]. 1980. The California Desert Conservation Area Plan, 1980. Sacramento, CA: Department of the Interior, Bureau of Land Management. USBLM [U.S. Bureau of Land Management]. 2016. Desert Renewable Energy Conservation Plan. Record of Decision for the Land Use Plan Amendment to the California Desert Conservation Area Plan, Bishop Resource Management Plan, and Bakersfield Resource Management Plan. U.S. Dept. of Interior, Bureau of Land Management. BLM/CA/PL2016/03+1793+8321.

USBLM [U.S. Bureau of Land Management]. 2019. West Mojave Route Network Project. Final Supplemental Environmental Impact Statement for the California Desert District. Moreno Valley, California. BLM/CA/DOI-BLM-CA-D080-20180008-EIS.

USDC [U.S. District Court]. 2009. Order summary judgment motions. Case 3:06-cv-04884-SI. Center for Biological Diversity, et al., Plaintiffs v. BLM. United States District Court for the Northern District of California, USA. Available at http:// www.biological diversity.org/programs/public_lands/deserts/ california_desert_conservation_area/pdfs/WEMO_NECO_ case_order_9_28_09.pdf.

USDC [U.S.DISTRICT COURT]. 2011. Order re: remedy.Case 3:06-cv04884-SI. Center for Biological Diversity, et al., Plaintiffs v. BLM. United States District Court for the Northern District of California, USA.

USDD [U.S. Dept. of Defense, Dept. of the Navy]. 2017. Record of Decision on the Supplemental environmental impact statement for land acquisition and airspace establishment to support large-scale Marine Air Ground Task Force live-fire and maneuver training at Marine Corps Air Ground Combat Center, Twentynine Palms, California, 10 February 2017. 
USDI [U.S. Dept. OF the INTERIOR]. 1990. Endangered and Threatened wildlife and plants: determination of Threatened status for the Mojave population of the Desert Tortoise. Federal Register 55:12178-12191.

USFWS [U.S. Fish and Wildlife Service]. 1980. Endangered and Threatened wildlife and plants: listing as Threatened with critical habitat for the Beaver Dam Slope population of the Desert Tortoise in Utah. Federal Register 45:55654-55666.

USFWS [U.S. Fish and WILDLIFE SeRVICE]. 1994. Desert Tortoise (Mojave population) Recovery Plan. Portland, OR: U.S. Department of the Interior, Fish and Wildlife Service.

USFWS [U.S. Fish AND WildLIFE SERVICE]. 2008. Environmental assessment to implement a Desert Tortoise Recovery Plan task: reduce Common Raven predation on the Desert Tortoise. Final. Ventura, CA: U.S. Department of the Interior, Fish and Wildlife Service.

USFWS [U.S. Fish and Wildlife Service]. 2010. Mojave Population of the Desert Tortoise (Gopherus agassizii). 5-Year Review: Summary and Evaluation. Reno, NV: Desert Tortoise Recovery Office, U.S. Department of the Interior, Fish and Wildlife Service.

USFWS [U.S. Fish AND WILdLIFE SeRvice]. 2011. Revised recovery plan for the Mojave population of the Desert Tortoise (Gopherus agassizii). Reno, NV: U.S. Department of the Interior, Fish and Wildlife Service.

USFWS [U.S. Fish and Wildlife Service]. 2015. Range-wide Monitoring of the Mojave Desert Tortoise (Gopherus agassizii): 2013 and 2014. Annual Report. Reno, NV: U.S. Department of the Interior, Fish and Wildlife Service.

USGCRP[U.S. Global Change Research Program]. 2017.Climate Science Special Report: Fourth National Climate Assessment, Volume 1. Wuebbles, D.J.,Fahey,D.W.,Hibbard,K.A., Dokken, D.J., Stewart, B.C., and Maycock, T.K.(Eds.). Washington, DC: U.S. Global Change Research Program, 470 pp.

UptaIn, C. 1983. Activities and their impacts on the Desert Tortoise Natural Area, Kern County, California. Report to California Department of Fish and Game, Inland Fisheries Branch, Rancho Cordova, California.

van Dijk, P.P., Stuart, B.L., and Rhodin, A.G.J.(Eds.). 2000. Asian Turtle Trade: Proceedings of a Workshop on Conservation and Trade of Freshwater Turtles and Tortoises in Asia. Chelonian Research Monographs No. 2, 164 pp.

VASEK,F.C. 1979.Early successional stages in Mojave Desert scrub vegetation. Israel Journal of Botany 23:133-148.

VASEK, F.C. 1980. Creosote bush: long-lived clones in the Mojave Desert. American Journal of Botany 67:246-255.

VASEK, F.C. 1983. Plant succession in the Mojave Desert. Crossosoma 9:1-23.

VASEK, F.C., JoHNSON, H.B., AND EsLINGER, D.H. 1975a. Effects of pipeline construction on creosote bush scrub vegetation of the Mojave Desert. Madroño 23:1-12.

VASEK, F.C., Johnson, H.B., And BRum, G.D. 1975b. Effects of power transmission lines on vegetation of the Mojave Desert. Madroño 23:114-129.

von SecKendorff Hoff, K. and Marlow, R.W. 2002. Impacts of vehicle road traffic on Desert Tortoise populations with consideration of conservation of tortoise habitat in southern Nevada. Chelonian Conservation and Biology 4:449-456.

VRedenburg, L.M.,Shumway, G.L, and Hartill, R.D. 1981. Desert Fever: An Overview of Mining in the California Desert. Living West Press.

W ALDE,A.D. AND CuRrYLow,A. 2015.Gopherus agassizii (Mojave Desert Tortoise) and Coleonyx variegatus variegatus (Desert
Banded Gecko). Spring burrow cohabitation. Herpetology Notes 8:501-502.

Walde, A.D., Delaney, D.K., Harless, M.L., and Pater, L.L. 2007a. Osteophagy by the Desert Tortoise (Gopherus agassizii). Southwestern Naturalist 52:147-149.

Walde, A.D.,Harless, M.L., Delaney, D., and Pater, L.L. 2007 b. Anthropogenic threat to the Desert Tortoise (Gopherus agassizii): litter in the Mojave Desert. Western North American Naturalist 67:147-149.

Walde, A.D., Walde, A.M., And Delany, D.K. 2008. Gopherus agassizii (Desert Tortoise). Predation. Herpetological Review 39:214.

Walde, A.D, Walde, A.M., Delaney, D.K., And Pater, L.L. 2009. Burrows of Desert Tortoises (Gopherus agassizii) as thermal refugia for Horned Larks (Eremophila alpestris) in the Mojave Desert. Southwestern Naturalist 54:375-381.

Walde,A.M.,W ALDE,A.D., AND Jones, C. 2014.Gopherus agassizii (Mohave Desert Tortoise) and Crotalus mitchellii (Speckled Rattlesnake). Burrow associate. Herpetological Review 45:688.

Walde, A.D., Currylow, A., And Walde, A.M. 2015. Discovery of a new burrow associate of the Desert Tortoise (Gopherus agassizii), the Long-nosed Leopard Lizard (Gambelia wislizenii). Herpetology Notes 8:107-109.

Wallis, I.R., Henen, B.T., And Nagy, K.A. 1999. Egg size and annual egg production by female Desert Tortoises (Gopherus agassizii): the importance of food abundance, body size, and date of egg shelling. Journal of Herpetology 33:394-408.

Webb, R.H. and Stielstra, S.S. 1979. Sheep grazing effects on Mojave Desert vegetation and soils. Environmental Management 3:517-529.

WeBb,R.H. AND WiLShIRE,H.G.(EDS.). 1983.EnvironmentalEffects of Off-Road Vehicles. New York: Springer Verlag.

Webb, W.C., BoArman, W.I., AND Rotenberry, J.T. 2004. Common Raven juvenile survival in a human-augmented landscape. The Condor 106:517-528.

WebB,W.C.,BoARman, W.I.,AND Rotenberry, J.T.2009. Movements of juvenile Common Ravens in an arid landscape. Journal of Wildlife Management 73:72-81.

Weinstein, M.N. 1989. Modeling Desert Tortoise habitat: can a useful management tool be developed from existing transect data? Ph.D. Dissertation, University of California, Los Angeles.

Weinstein, M.N. AND BerRy, K.H. 1989. Morphometric analysis of Desert Tortoise populations. Riverside, CA: U.S. Department of the Interior, Bureau of Land Management.

Weitzman, C.L., SAndmeier, F., And Tracy, R. 2017. Prevalence and diversity of the upper respiratory pathogen Mycoplasma agassizii in Mojave Desert Tortoises (Gopherus agassizii). Herpetologica 73:113-120.

Weitzman, C.L., Tillett, R.L., SAndmeier, F.C., Tracy, C.R., And Alvarez-Ponce, D. 2018. High quality draft genome sequence of Mycoplasma testudineum strain $\mathrm{BH} 29^{\mathrm{T}}$, isolated from the respiratory tract of a Desert Tortoise. Standards in Genomic Sciences 13:9.

Wentworth, E.N. 1948. America's Sheep Trails. Iowa State College Press.

WiLSHIRE, H.G. AND NAKATA, J.K. 1976. Off-road vehicle effects on California's Mojave Desert. California Geology 29:123-132.

Wilson, D.S., Tracy, C.R., Nagy, K., And MorafKa, D.J. 1999a. Physical and microhabitat characteristics of burrows used by juvenile Desert Tortoises (Gopherus agassizii). Chelonian Conservation and Biology 3:448-453.

Wilson, D.S., MorafKa, D.J., Tracy, C.R., and Nagy, K.A. 1999b. Winter activity of juvenile Desert Tortoises (Gopherus agassizii) 
in the Mojave Desert. Journal of Herpetology 33:496-501. Wilson,D.S.,NAGy,K.A.,Tracy, C.R., MorafKa, D.J., and Yates, R.A.2001. Waterbalance in neonate and juvenile Desert Tortoises, Gopherus agassizii. Herpetological Monographs 15:158-170.

WoODBURY,A.M. ANDHARDY,R. 1948. Studies of the Desert Tortoise, Gopherus agassizii. Ecological Monographs 18:145-200.

Woodman, A.P., Walde, A.D., And Boarman, W.I. 2013.Predation of adult Agassiz's Desert Tortoise by Common Ravens in the central Mojave Desert. Abstract. 38th Annual Desert Tortoise Council Symposium, 2013, http://deserttortoise.org.

Wyneken, J., Mader, D.R., Weber, E.S., III, and Merigo, C. 2006. Medical care of sea turtles. In: Mader, D.R. (Ed.). Reptile Medicine and Surgery. Saunders Elsevier, Inc. USA, pp. 972-1007.

Zimmerman, L.C., O'Connor, M.P., Bulova, S.J., Spotila, J.R., Kemp, S.J., and SAlice, C.J. 1994. Thermal ecology of Desert
Tortoises in the eastern Mojave Desert: seasonal patterns of operative and body temperatures, and microhabitat utilization. Herpetological Monographs 7:45-59.

\section{Citation Format for this Account:}

BERRY, K.H. AND MuRPHy, R.W.2019. Gopherus agassizii (Cooper 1861) - Mojave Desert Tortoise, Agassiz's Desert Tortoise. In: Rhodin, A.G.J., Iverson, J.B., van Dijk, P.P., Stanford, C.B., Goode,E.V.,Buhlmann,K.A.,Pritchard,P.C.H., and Mittermeier, R.A. (Eds.). Conservation Biology of Freshwater Turtles and Tortoises: A Compilation Project of the IUCN/SSC Tortoise and Freshwater Turtle Specialist Group. Chelonian Research Monographs 5(13):109.1-45.doi: 10.3854/crm.5.109.agassizii. v1.2019; www.iucn-tftsg.org/cbftt/. 